\title{
اختلاف القراءات وأثره في التفسير
}

إعداد

أ/ مريم عماد الشيخ

الماجستير في تخصص الكتاب والسنة، قسم الثريعة والداراسات

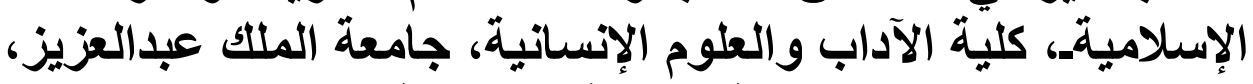
المملكة العربية السعودية الآنية جائة 
- rrt. - 
اختلاف القراعات وأثره في التفسير

مريم عماد الشيخ

قسم الثريعة والدراسات الإسلامية ، كلية الآداب والعلوم الإنسانية ، جامعة الملك

عبد العزيز، المملكة العربية السعودية .

البريد الاكتروني: maryamsh1.9r@gmail.com

ملخص:

يتناول هذا البحث اختلاف القراءات وأثره في التفسير، مفهوم القراءات، واختلاف

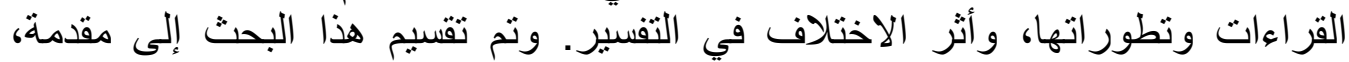

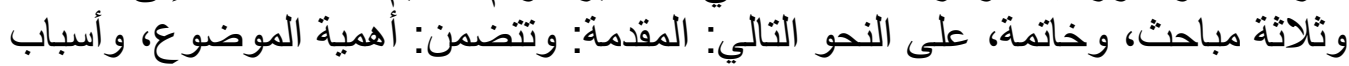

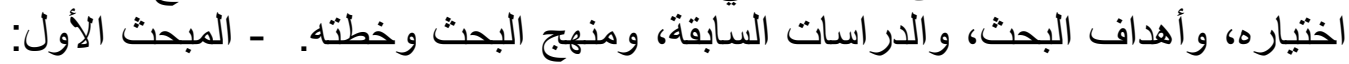

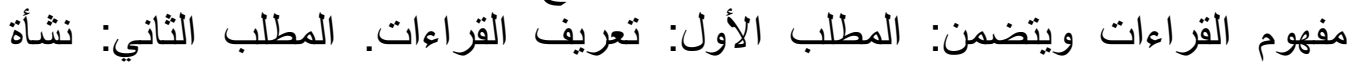

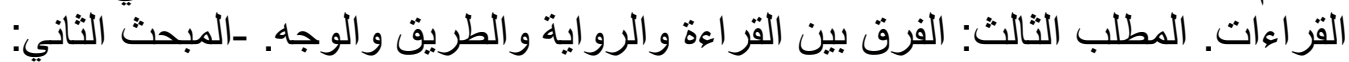

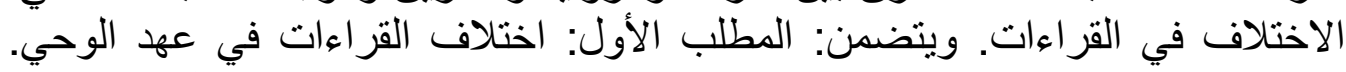

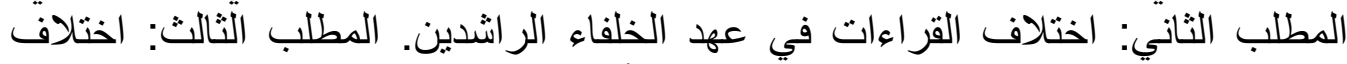

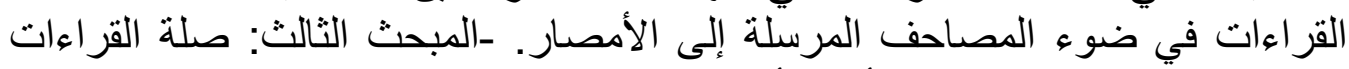

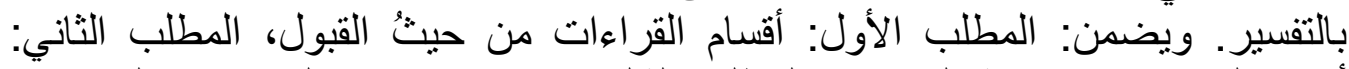

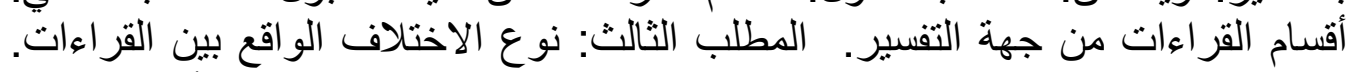

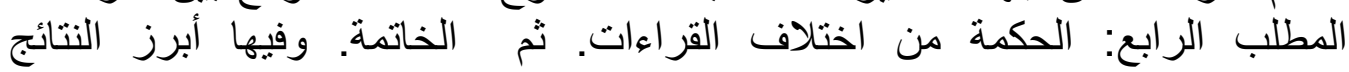
و التوصيات. - و التعب.

الكلمات المفتاحية: اختلاف القراءات، التفسير، الرواية، القراءة ، المفسرين . 


\section{Qira'at Differences and its Influence on Interpretation}

Maryam Imad Al-Sheikh

Department of Sharia and Islamic Studies, Faculty of Arts and Humanities, King's University

Abdulaziz, Kingdom of Saudi Arabia.

Email: maryamsh1.9r@gmail.com.

\section{ABSTRACT:}

This research deals with different readings and their effect on interpretation, the concept of readings, different readings and their developments, and the effect of difference in interpretation. This research was divided into an introduction, three topics, and a conclusion, as follows: Introduction: It includes: the importance of the topic, reasons for choosing it, research objectives, previous studies, research methodology and its plan. The first topic: the concept of readings, and it includes: The first requirement: the definition of readings. The second requirement: the genesis of readings. The third requirement: the difference between reading, narration, path and face. The second topic: the difference in readings. It includes: The first requirement: the different readings in the era of revelation. The second requirement: the different readings during the era of the Rightly Guided Caliphs. The third requirement: the difference in readings in the light of the Qur'ans sent to the regions. The third topic: the relevance of readings to interpretation. It guarantees: The first requirement: sections of the readings in terms of acceptance, the second requirement: sections of the recitations from the point of interpretation. The third requirement: the type of difference between the readings. Fourth requirement: wisdom from different readings. Then the conclusion. And it contains the most prominent findings and recommendations.

Key Words: Qira'at Differences, Interpretation, Novel, reading, commentators. 


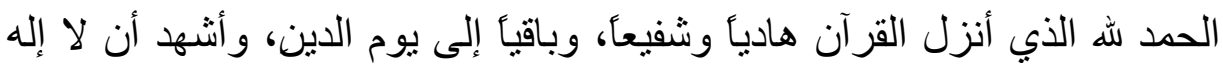

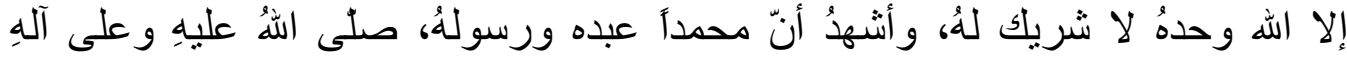

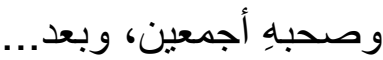

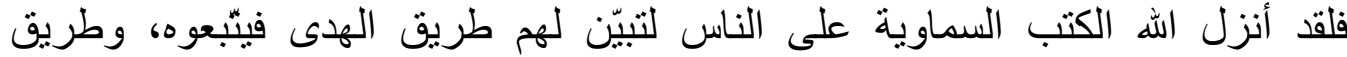

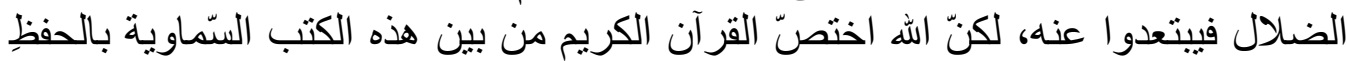

إلىى أن تقوم السّاعة، فقال:

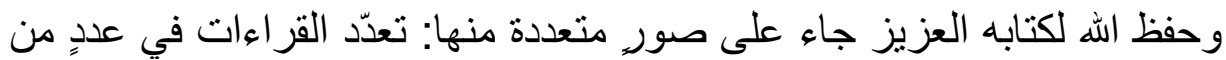

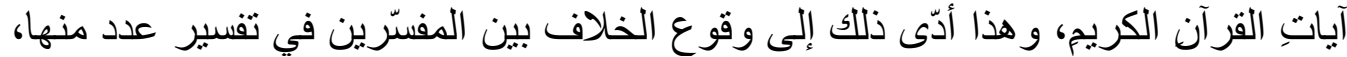

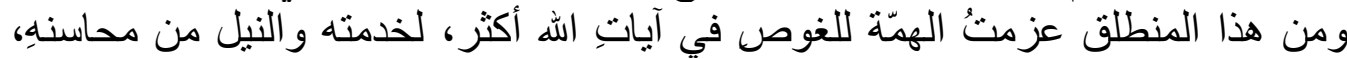
وسأتناول في هذا البحث - بإذن الله تعالى - عن أثن التخ اختلاف القر اءعات في التفسير.

قضية البحث:

إنّ في تعدد القراءات واختلافها أثرأ في تعدد دلالة الآية الوحدة، وهذه الإها

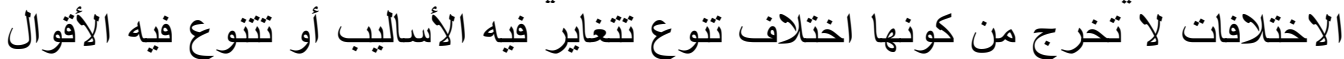

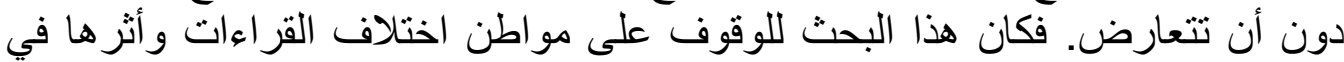

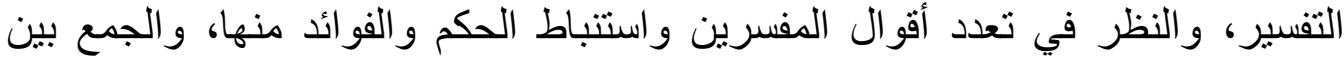

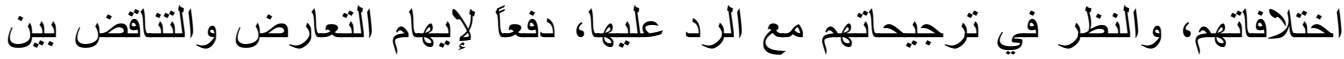

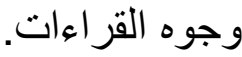

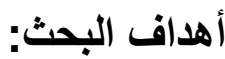

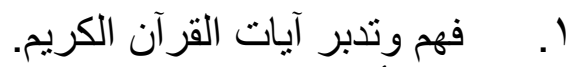

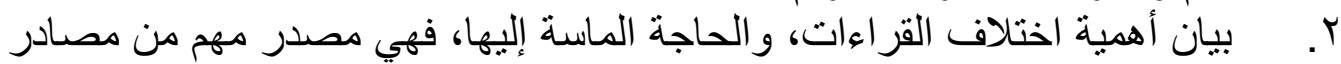
التفسير.

؟. الرغبة في الكثنف عن توجيه القر اعة تفسيرآ، ولغة، و إعراباً.

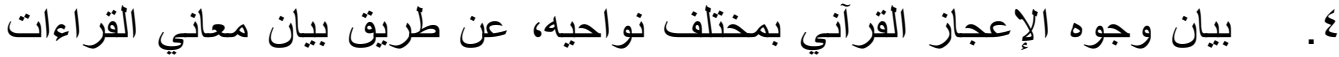

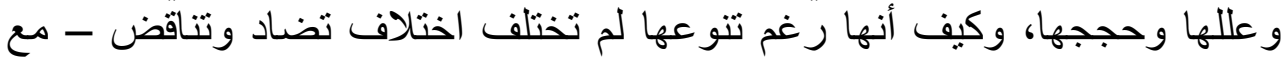

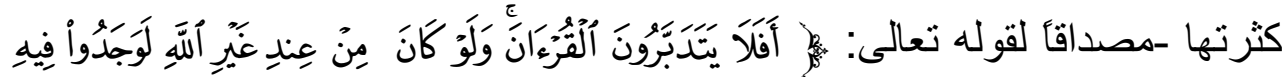

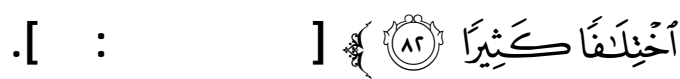
○. بيان معنى الآية التي قرئت بأكثر من وجه وتفسير ها؛ فيكون الباعث على ذللك

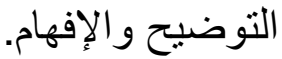


تبرز أهمية الدراسة في أنها تتعلق بأمرين هامين هما:

بـ- فهي توضح أثر اختلاف القر اءعات في التفسير، و القراءة الصحيحة المتواترة، وما يعتمد

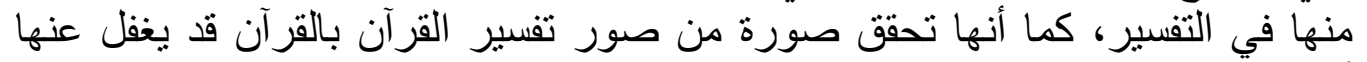

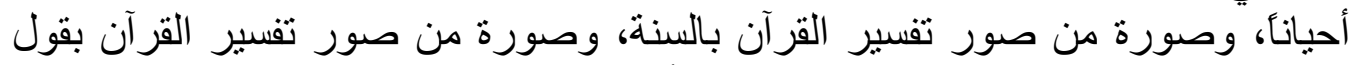

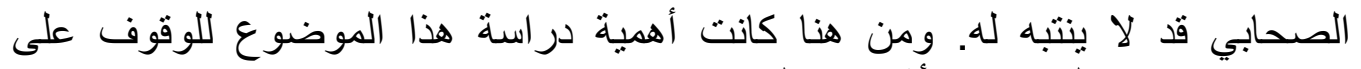

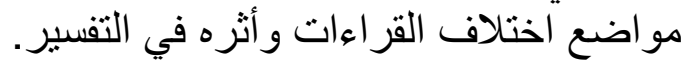

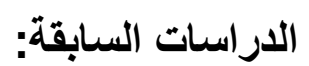

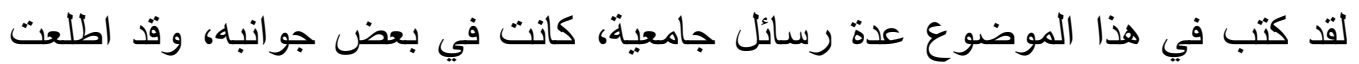

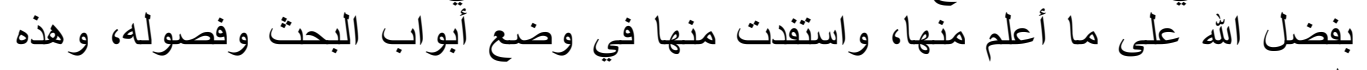

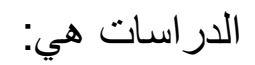

ا. رسالة دكتور اه بعنوان: " اختلاف القراعات وأثره في التفسير واستنباط الأحكام

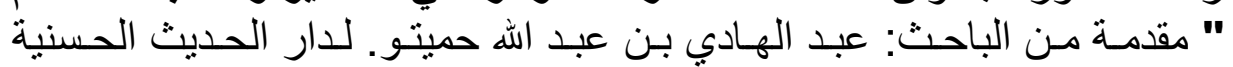

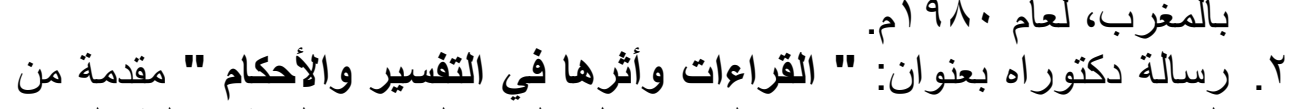

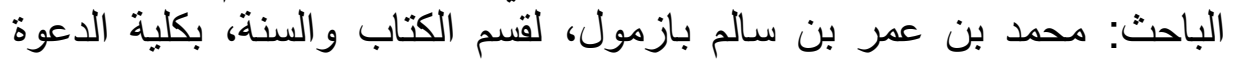

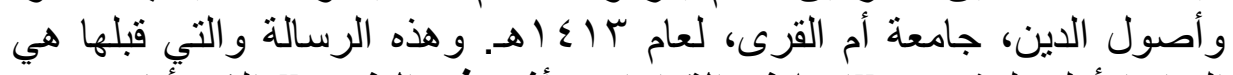

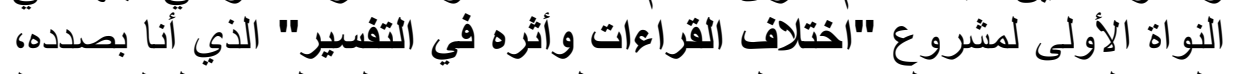

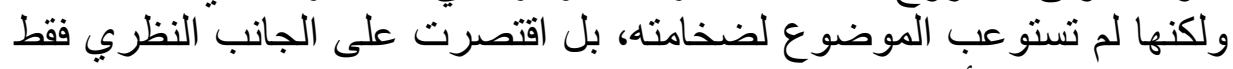

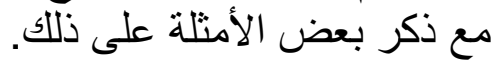

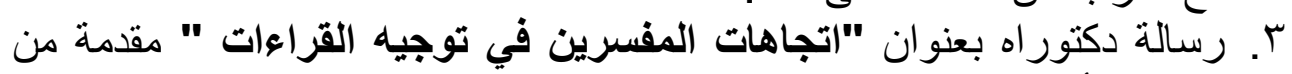

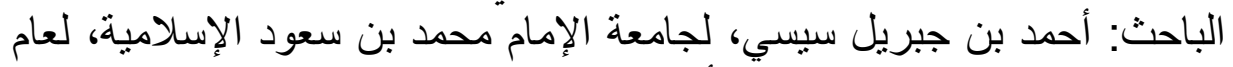

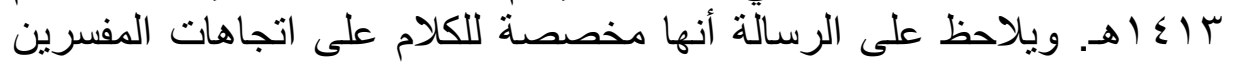

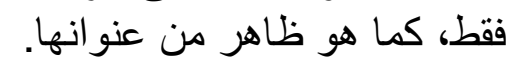
ع. رسالة دكتور اه بعنوان "أثر اختلاف القراعات في الأحكام الفقهية" من الباحث:

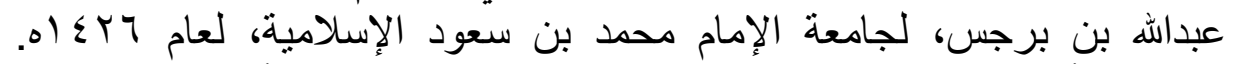

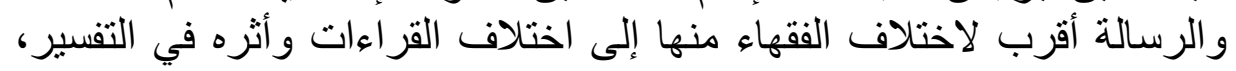
و هذا واضح من خلال الرسالة.

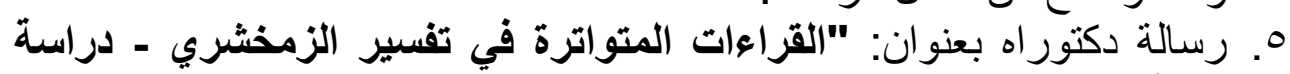

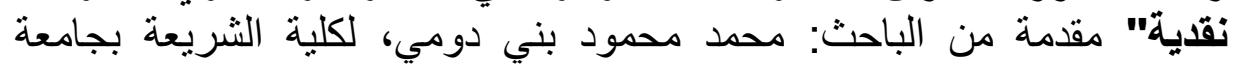

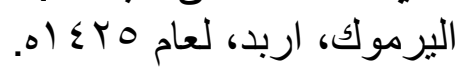


7 7. رسالة ماجستير بعنوان: "القراعات الواردة في تفسير معالم التنزيل للإمام

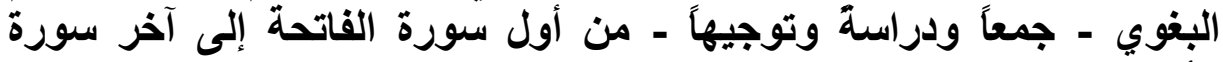

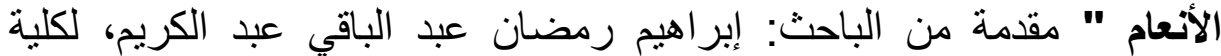

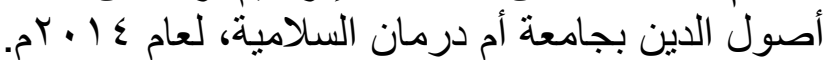

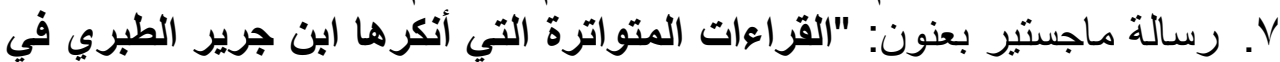

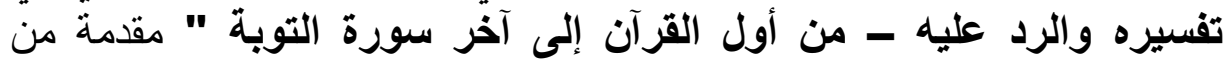

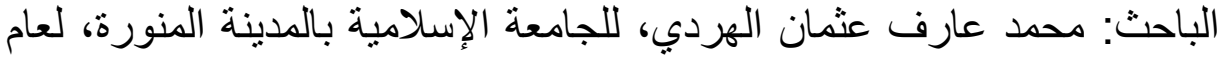
.0) $\varepsilon .7$ ^. رسالة بعنوان: "ابن جرير الطبري ومنهجه في توظيف القراعات القرآنية من

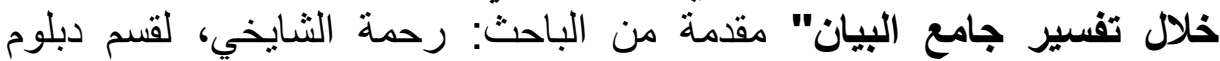

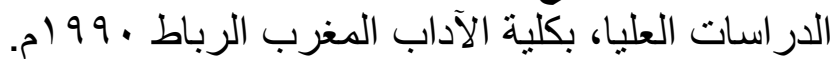

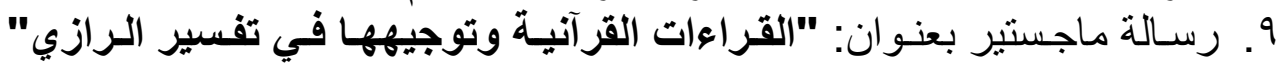

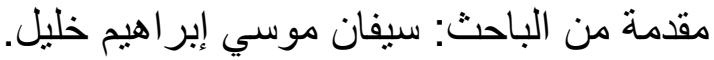

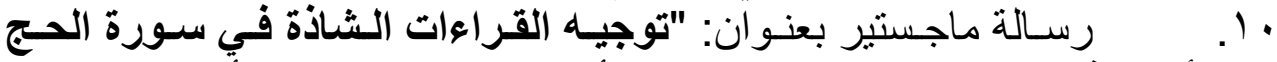

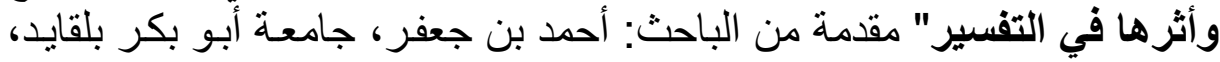

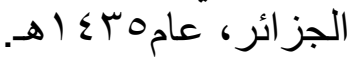

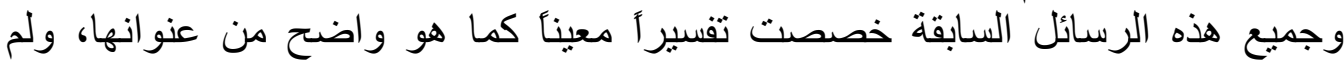

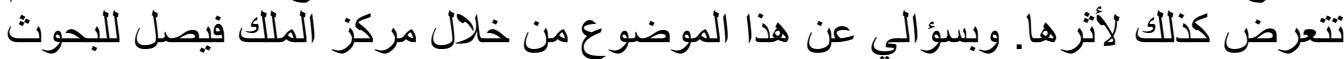

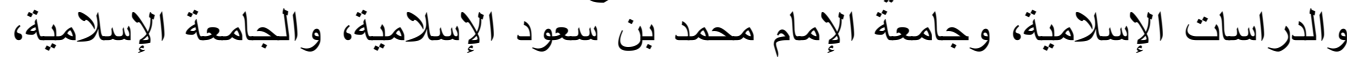

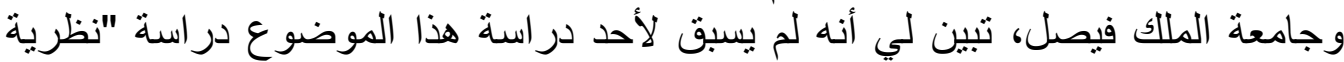

تطبيقية".

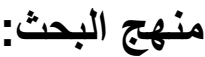

ومنهجي في البحث كان على اتجاهين هما:

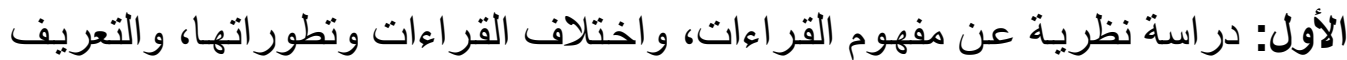

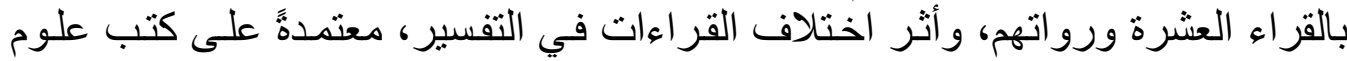
القرآن، وكتب التاريخ، وكتب التر اجم، و وغير ها مما يلزم. الثاني: در اسة استقر ائية استتناجية، وذلك من خلال الترتيب التالي:

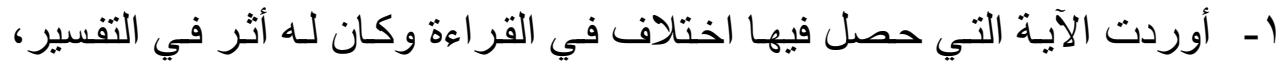

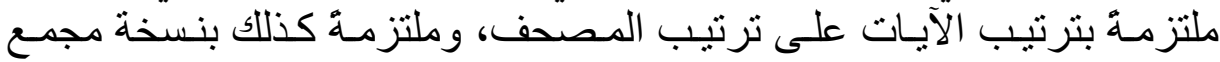

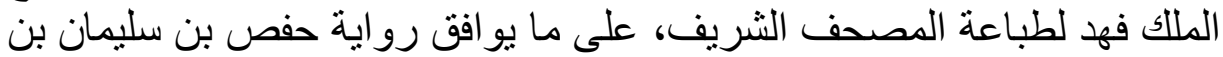

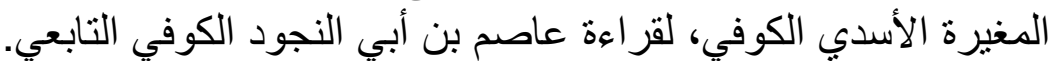

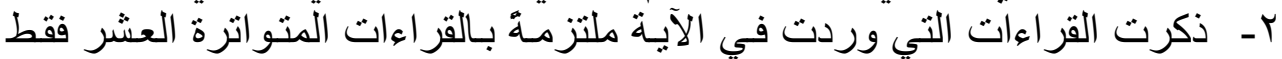
و أهملت ما سو اها، تحت عنوان: " القراعات الواردة الودة في الآية ". 


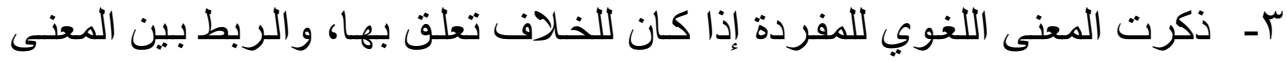

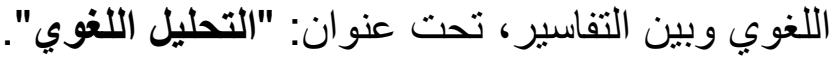

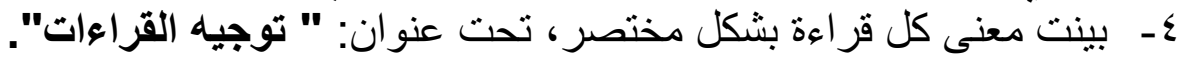

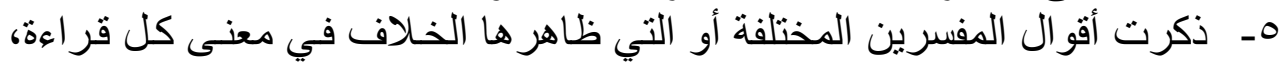

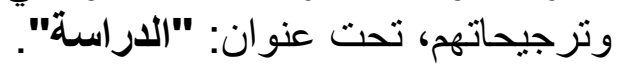

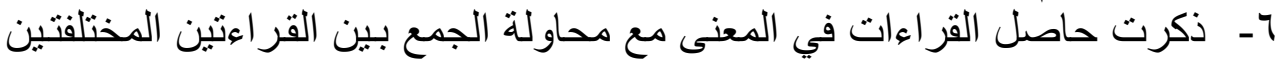

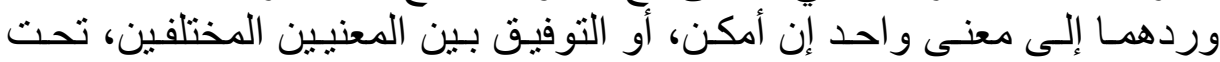

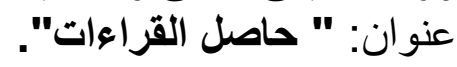

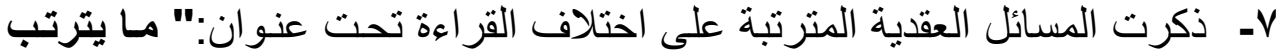

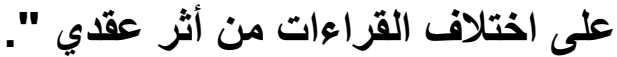

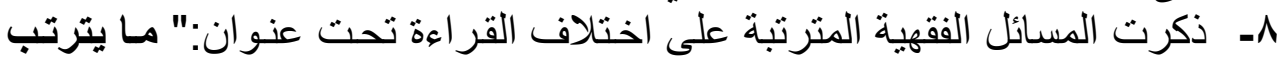
على اختلاف القراعات من أثر فقهي ".

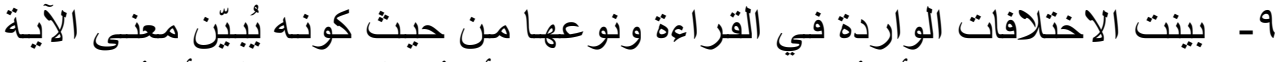

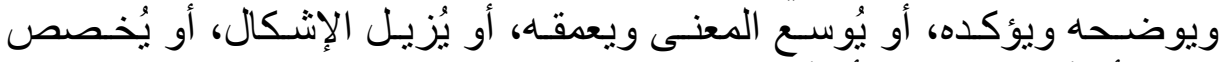

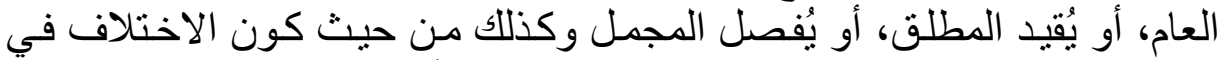

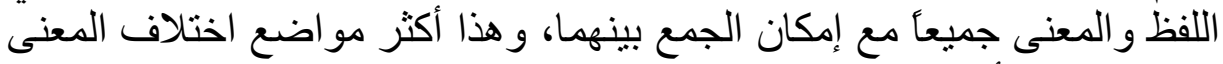

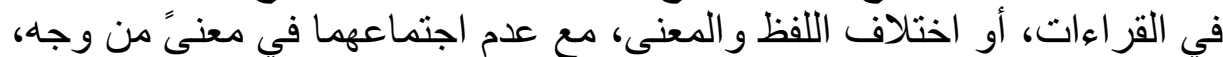

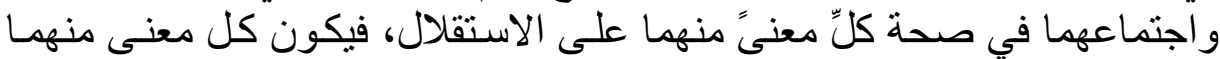

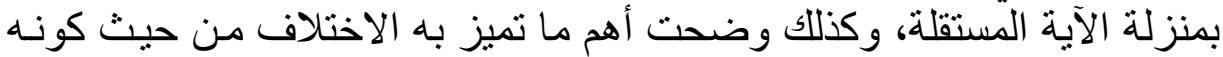

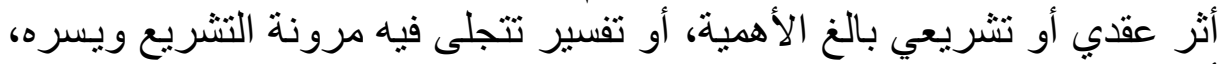

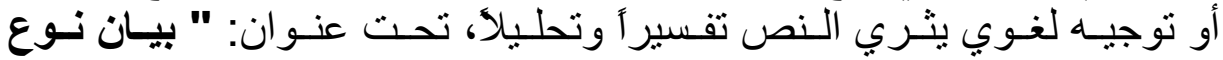

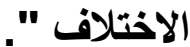
• ا ـ إن وجدت فائدة في الأقو ال المذكورة أو في قول منها ذكرتها ونبهت عليها في

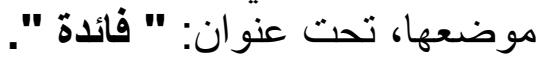
معتمدةً في ذلك على كتب توجيـه القراءات، وكتب التفاسير، وكتب الفقه المقارن

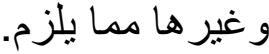

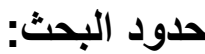

يتناول هذا البحث اختلاف القراءات و أثره في التفسير، مفهوم القراءات، و واختلاف واتف القراءات وتطور اتها، وأثر الاختلاف في التفسير. 


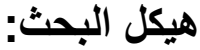

قسمت هذا البحث إلى مقدمة، وثلاثة مباحث، وخاتمة، على النحو التالي: المقدمة: وتتضمن:

أهمية الموضوع، و أسباب اختياره، و وأهداف البحث، والدراسات السابقة، ومنهج البحث وخطته.

- المبحث الأول: مفهوم القراعات. المطلب الأول: تعريف القراءات. المطلب الثاني: نشأة القراءات. المطلب الثالث: الفرق بين القراءة والرواية و الطريق و الوجه. - المبحث الثاني: الاختلاف في القراءات. المطلب الأول: اختلاف القراءات في عهز الوحي. المطلب الثاني: اختلاف القراءات في عهد الخلفاء الر اثدين. المطلب الثالث: اختلاف القراءات في ضوء المصاحف المرسلة إلى الأمصار. ـ المبحث الثالث: صلة القراعات بالتفسير. المطلب الأول: أقسام القر اءات من حيثُ القبول: المطلب الثاني: أقسام القراءات من جهة التفسير. المطلب الثالث: نوع الاختلاف الو اقع بين القراءات.

المطلب الرابع: الحكمة من اختلاف القراءات(') الخاتمة. وفيها أبرز النتائج و التوصيات. 


\section{المبمث الأول}

\section{تعريف القراءات، ونشأتها، والفرق بينها وبين الرواية والطريق والوجه.}

\section{المطلب الأول}

\section{تعربف القُراءات.}

أولاً: القزاعات لغةة: - اءة

القراءات: جمع قر اءة، و هي مصدر سماعي لقرا يقر أ قر اءة(') ، وبـالرجوع إلى لي

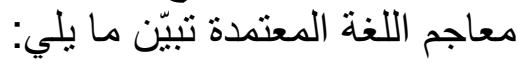

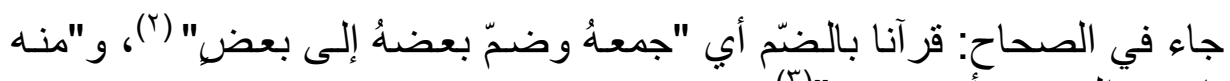
قر أتُ الماء في الحوض أبي جمعته" ().

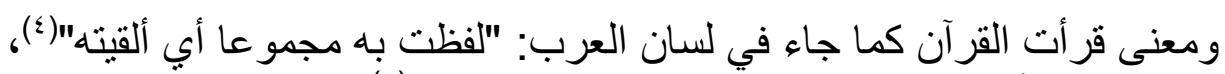

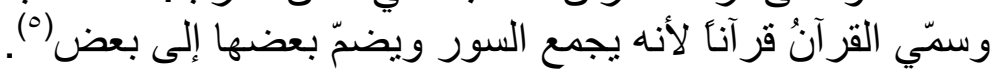

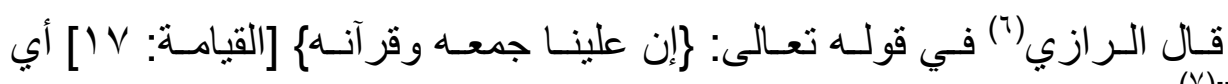

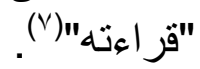

( ()ينظر: مجد الدين بن محمد الجزري ابن الأثير، ت: 7 ـ 7 هـ، النهاية في غريب الحديث والأثر،

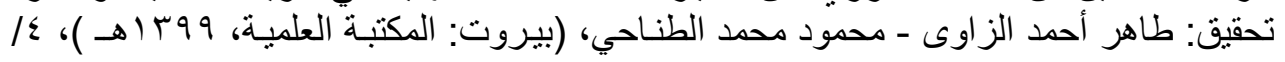
r.

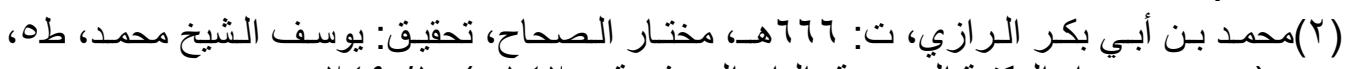

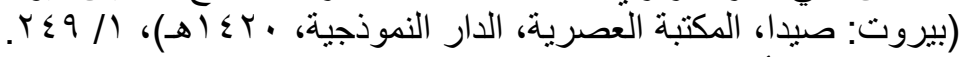

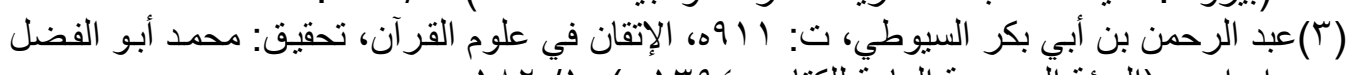

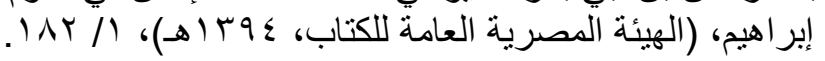

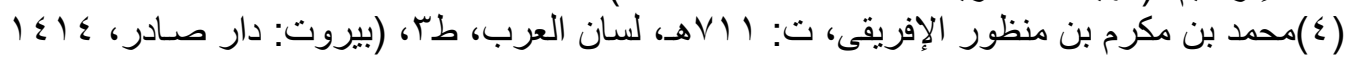
هـ)،

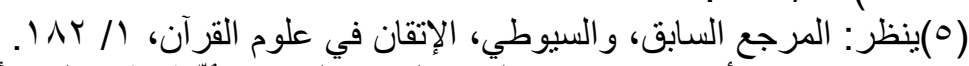

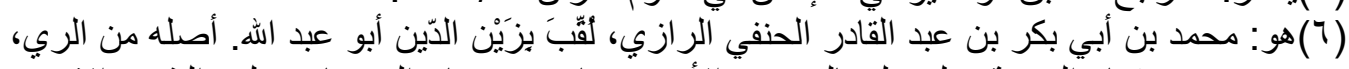

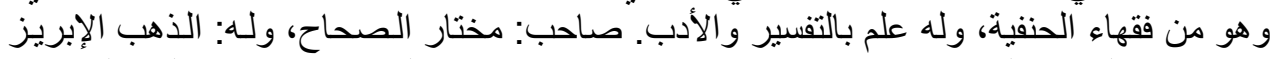

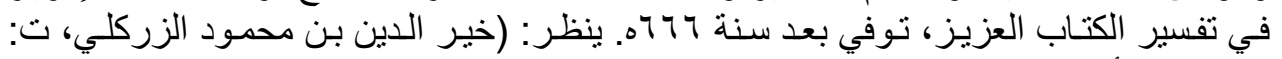

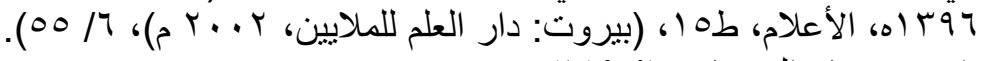




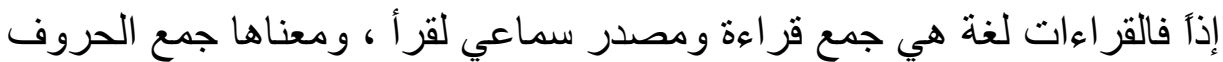

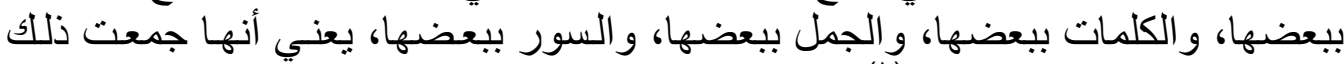

كله وضمته في القرآن الكريم) '(').

ثانياً: القزاعات اصطلاحاً:

تعدّدت التّعاريف واختلفت عند القرّاء في تعريف القر اءات، ولعلّ أحسنها جمعًا

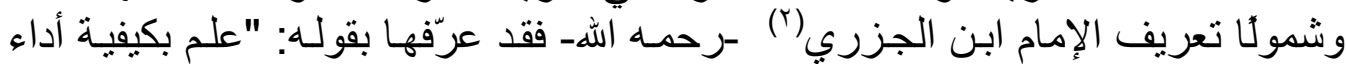

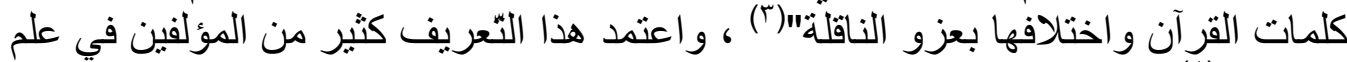

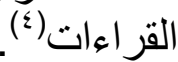

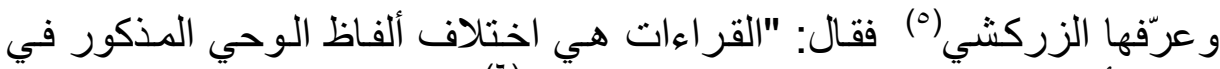

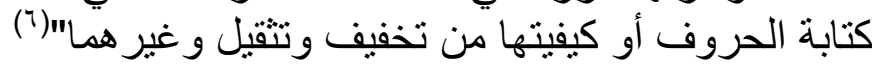

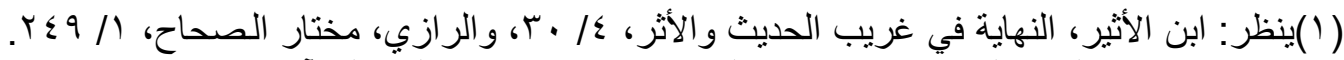

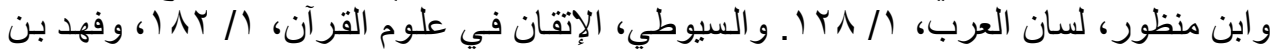

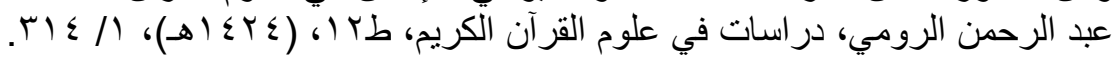

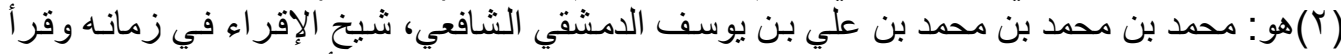

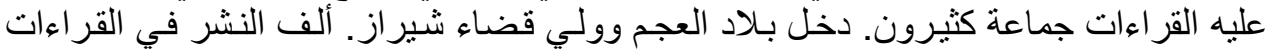

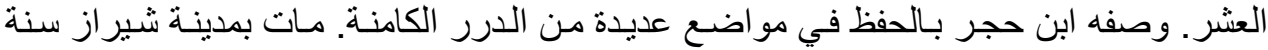

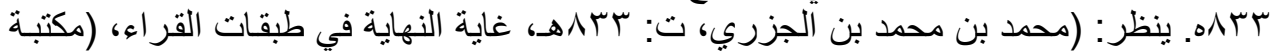

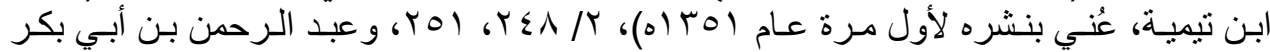

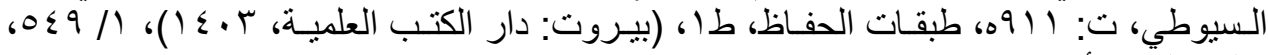

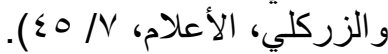

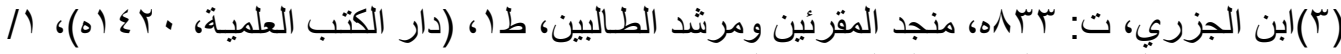

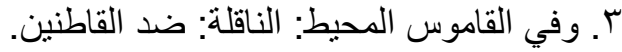

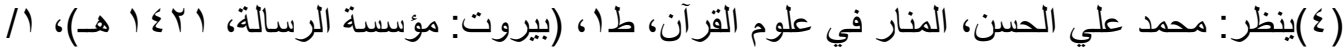
$11 \mathrm{~V}$

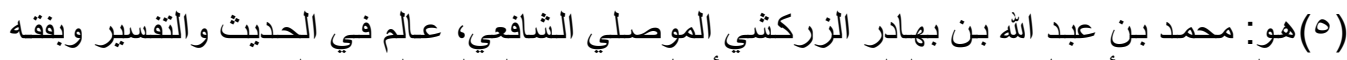

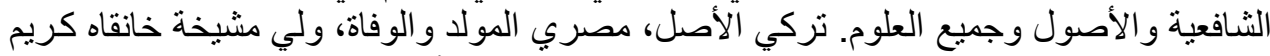

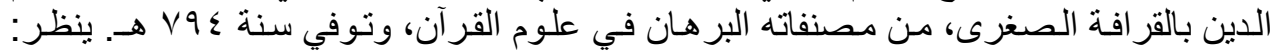

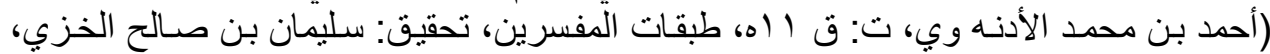

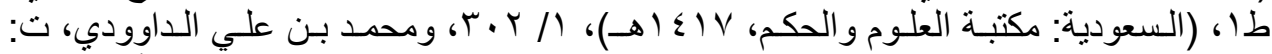

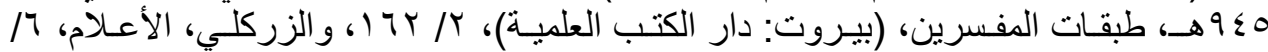

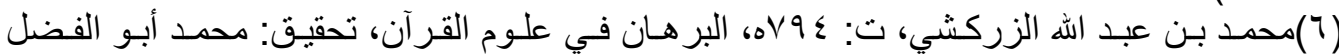

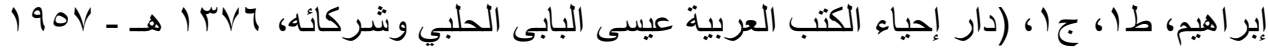




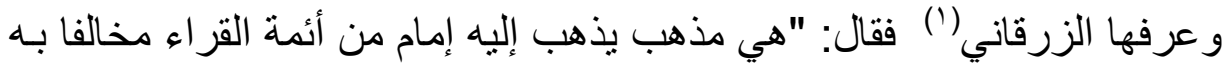

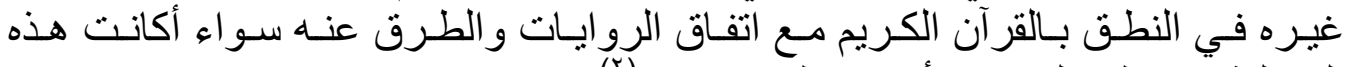

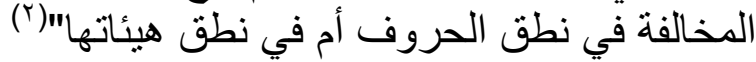

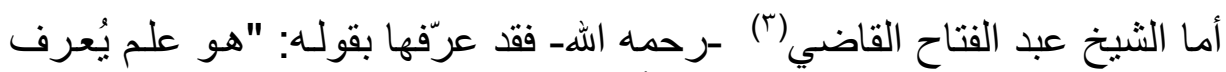

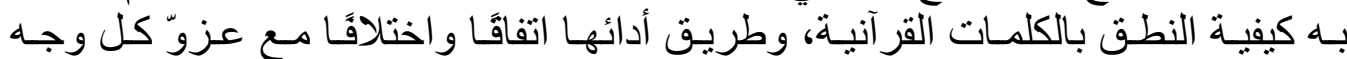

ويتضح لنا من خلال التعاريف السابقة أنّ القراءات هي العلمُ الذي يسلكه إمـام

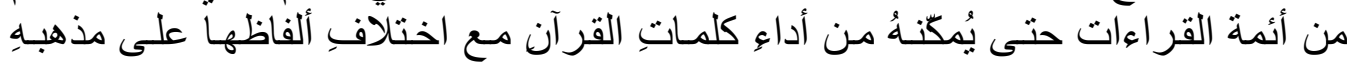

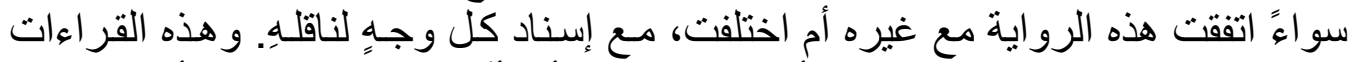

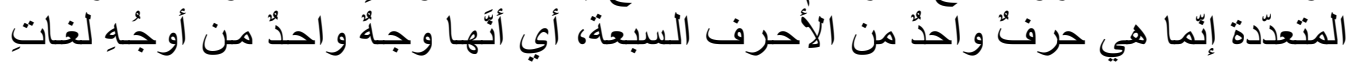

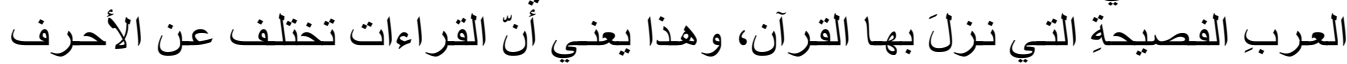

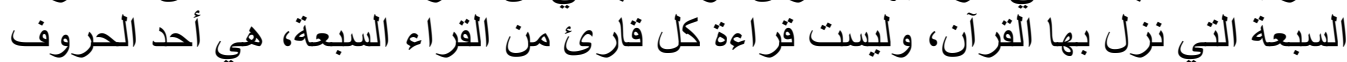

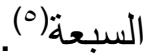

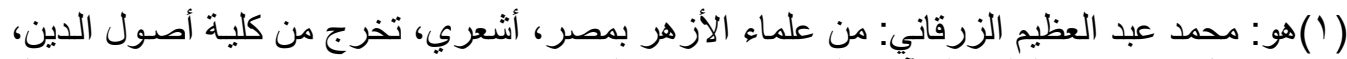

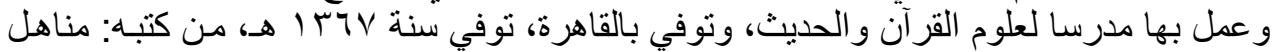

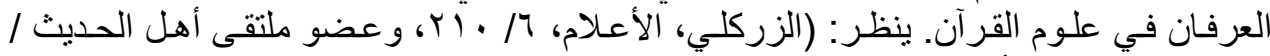

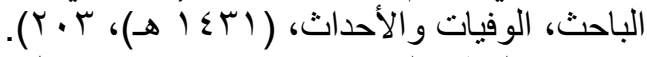

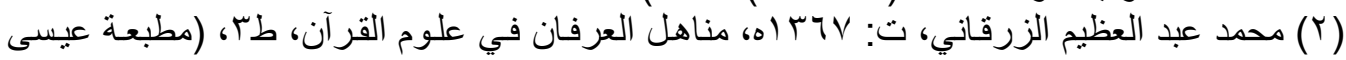

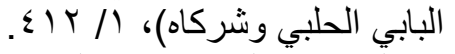

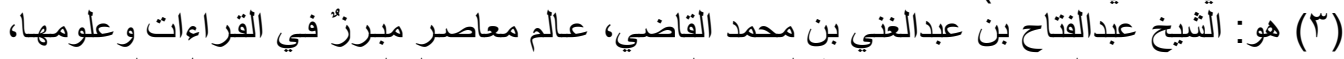

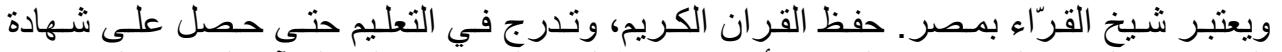

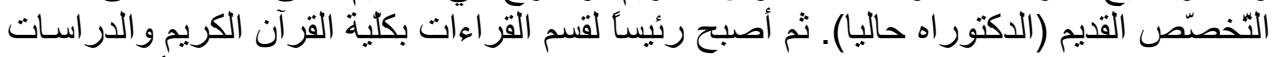

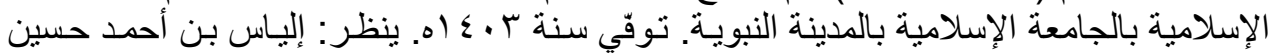

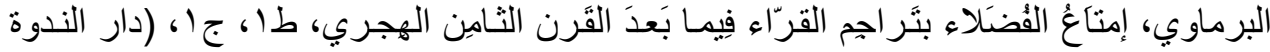

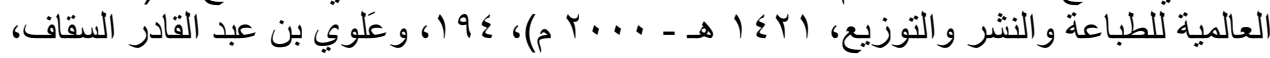

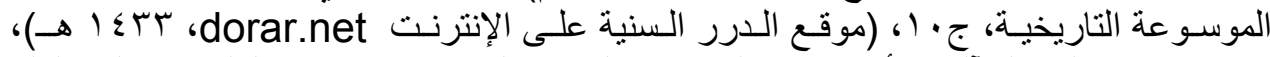

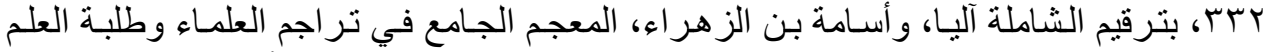

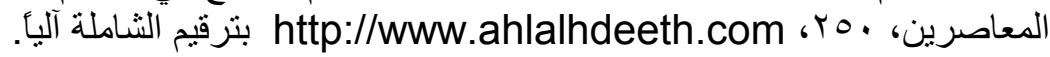

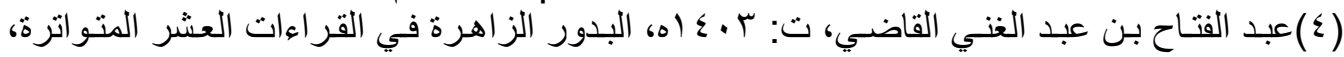

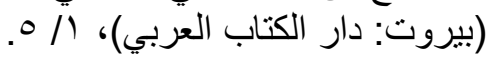

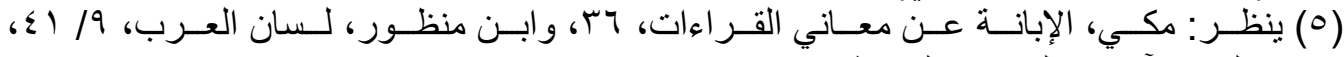
و الفيروز آبادى، القاموس المحيط، و99. V9. 


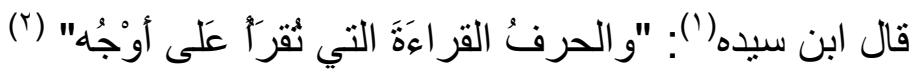

\section{1المطلب النانبي}

\section{نـشنأة القراءات}

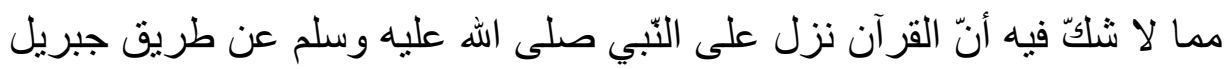

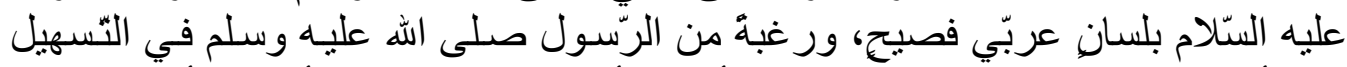

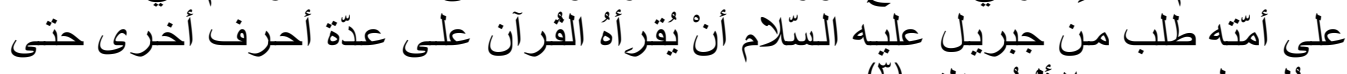

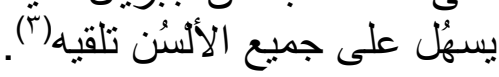

وقد ثبت في الصحيحين من حديث ابن عباس أن رسول الله صلى الله عليه وسلم

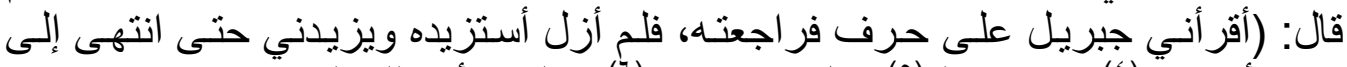

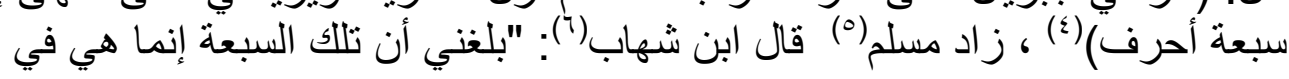

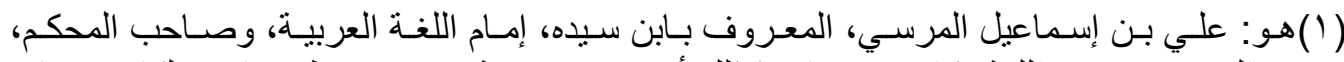

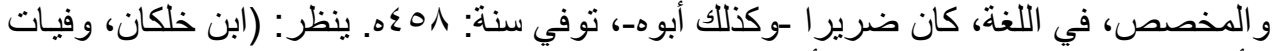

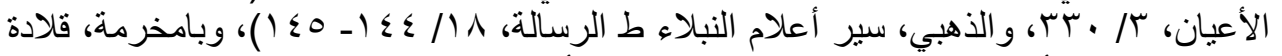

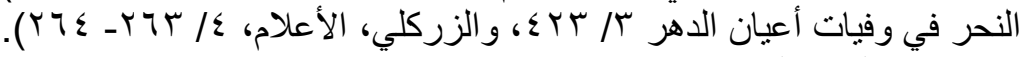

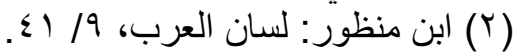

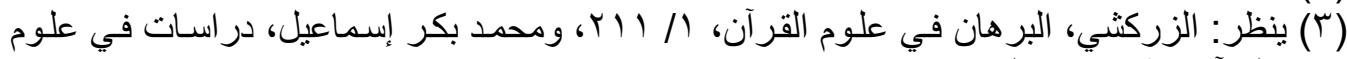

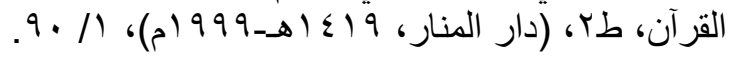

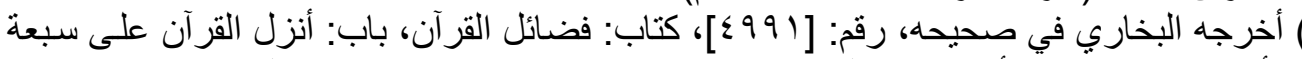

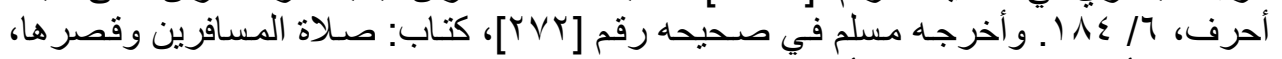

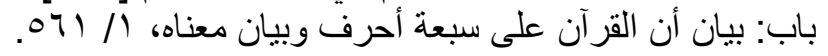

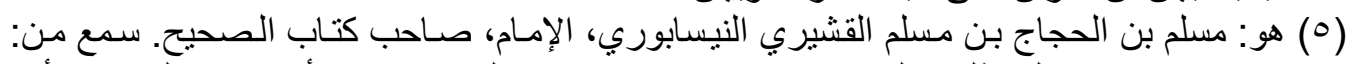

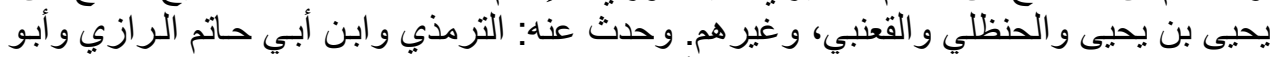

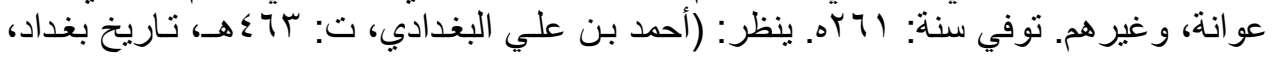

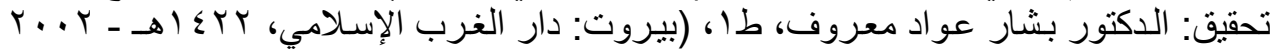

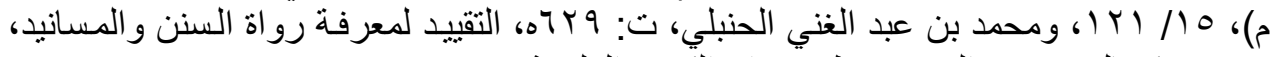

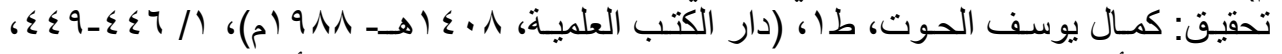

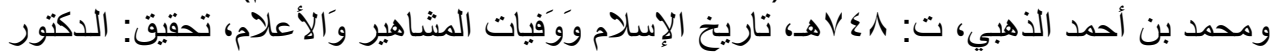

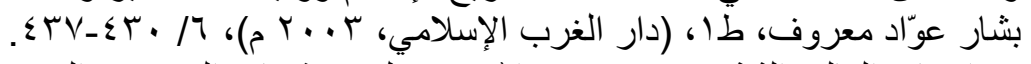

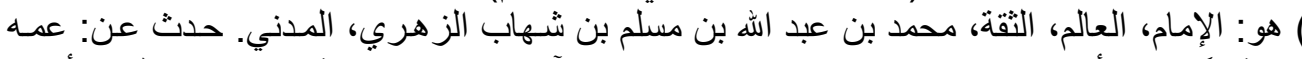

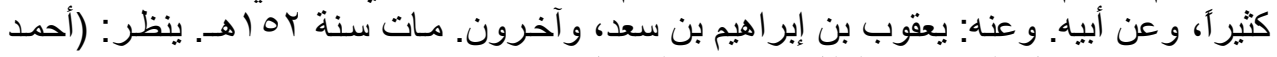

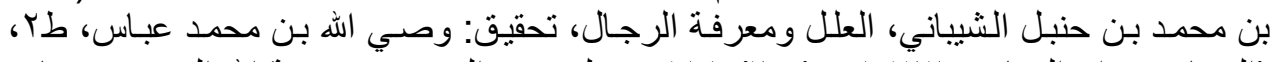

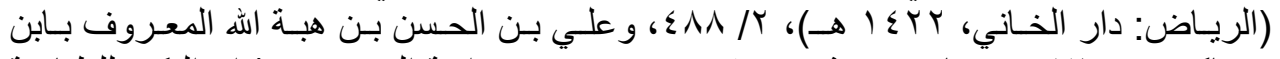

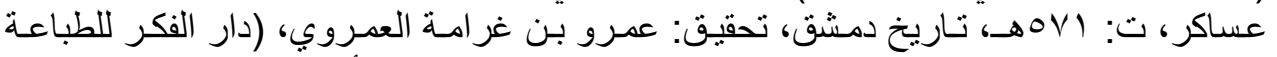

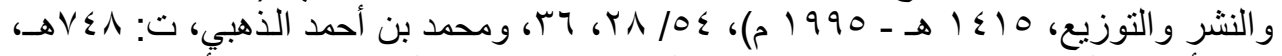

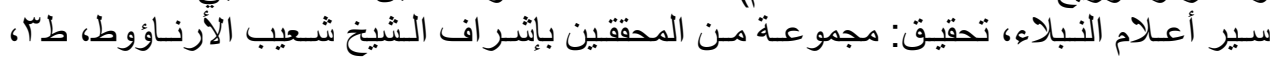


الأمر الذي يكون واحدا لا يختلف في حلال ولا حرام"(').

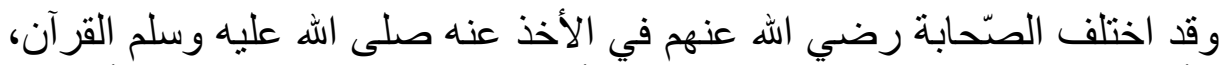

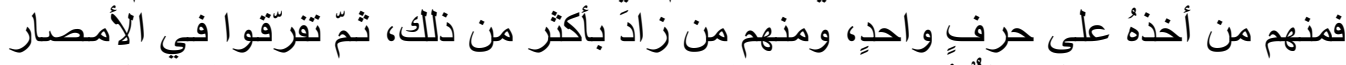

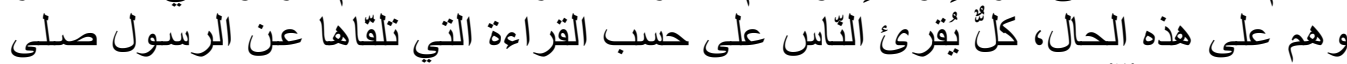

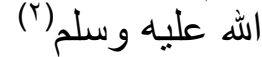

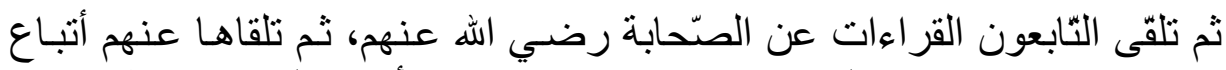

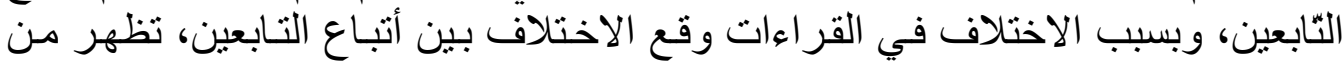

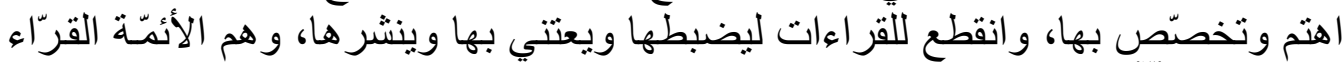

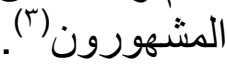

و هكذا نشأ علم القراءات واختلافها، وإن كان الاختلاف في الو اقع اختلافـأ في

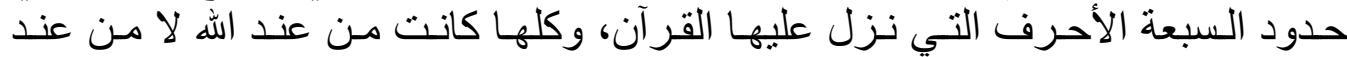

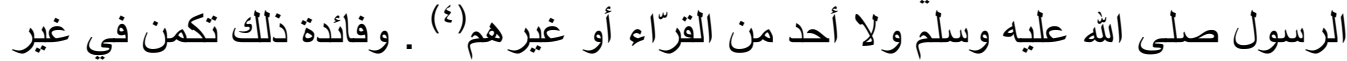

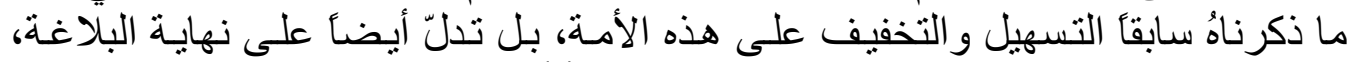

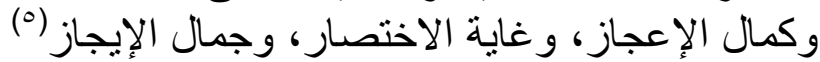

\section{المطlll}

\section{الفرق ببز القراءة والروابة والطربق والوجه}

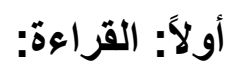

لغة: كما ذكرنا سابقا هي مصدر سماعي لقر أ يقر أ قر اءة(آ) ، و و"منه قر أتُ المـاء

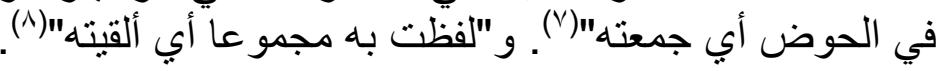

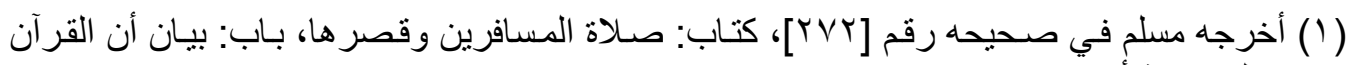

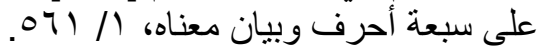

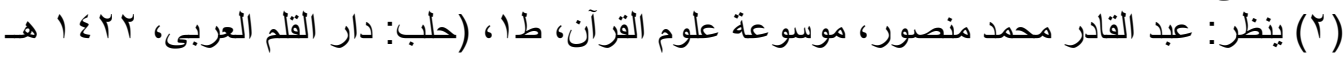

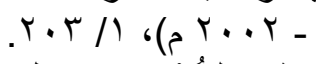

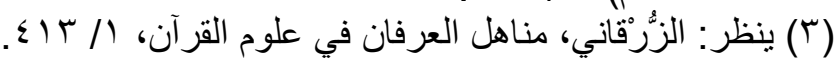

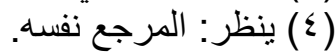

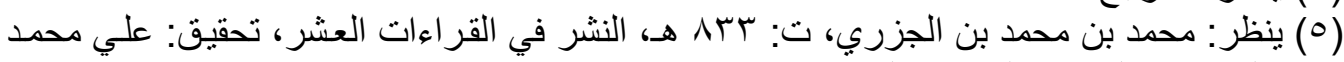

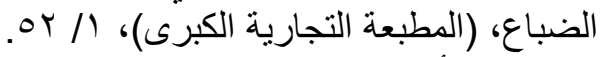

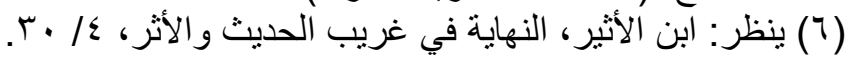

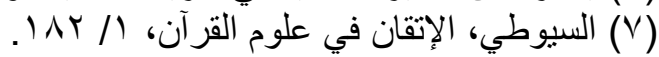


و واصطلاحاً: هي كلّ خلافٍ نسب إلى إمام من الأئمة القر اء مدن أجمعت عليه الرّو ايات

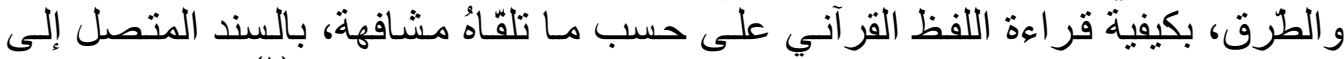

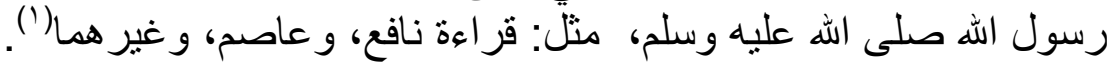
مثاله: إثبات البسملة بين السورتين قراءة ابن كثير و الكسائي و عاصم(؟)

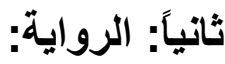

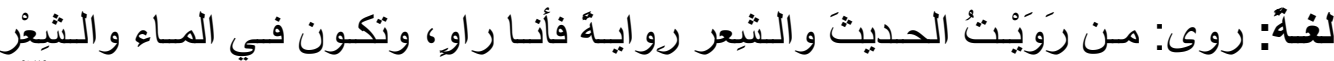

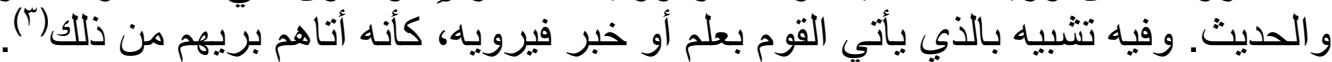

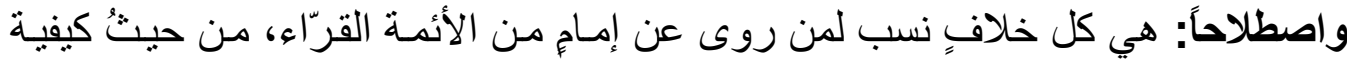

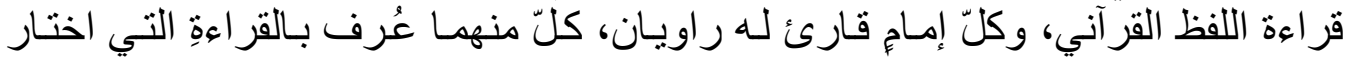

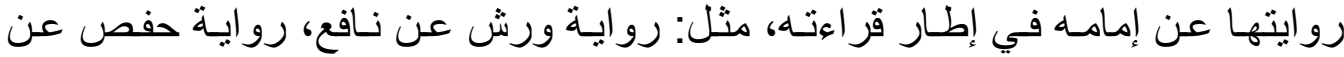
عاصم.

مثثاله: إثبات البسملة بين السورتين رواية قالون عن نافع(؛).

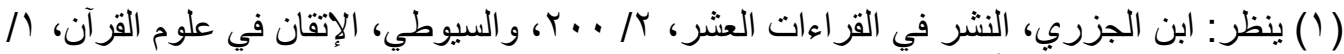

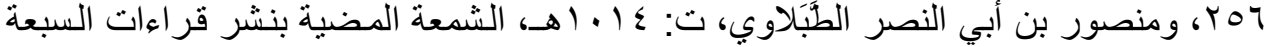

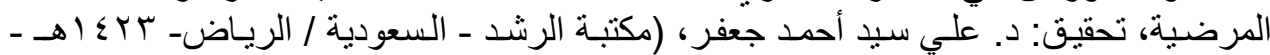

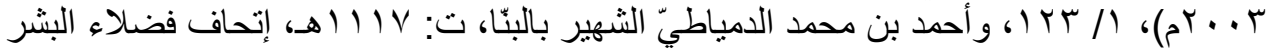

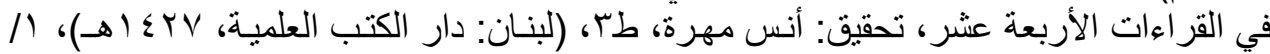

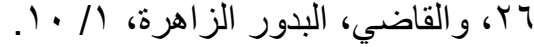

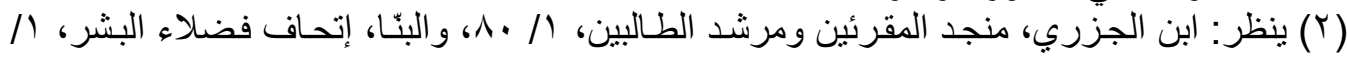
rا

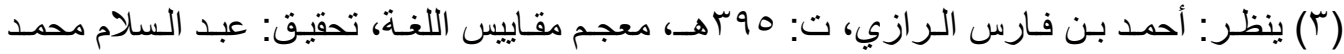

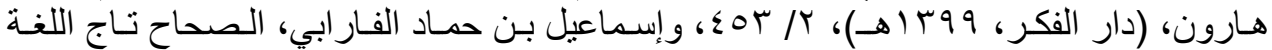

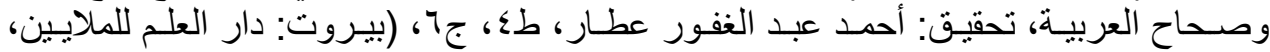
(

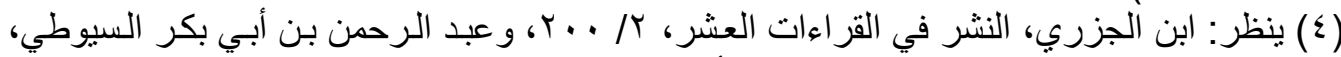

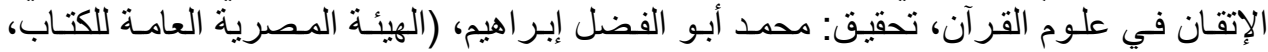

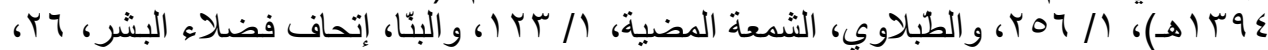

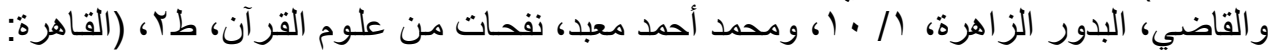




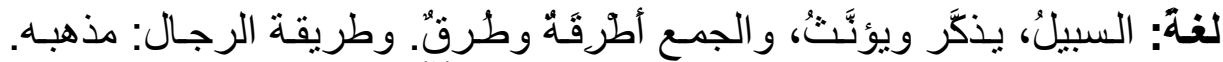

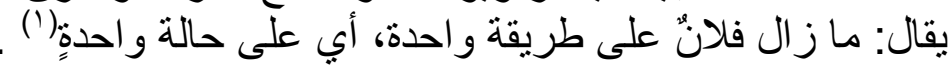

واصطلاحاً: هو كلّ خلاف نسب إلى الآخذ عن الراوي و إن سفل(؟). مثاله: ترك التسمية في القراءة من طريق الأزرق عن ورش(r).

رابعاً: الوجه:

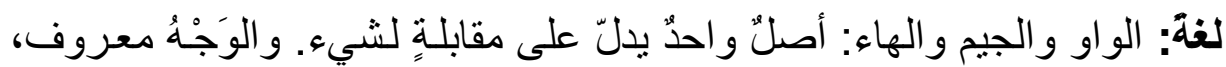

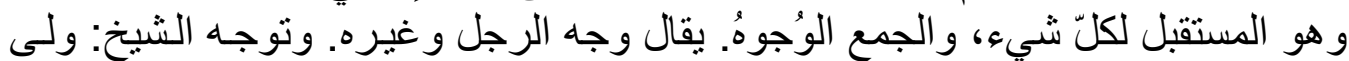

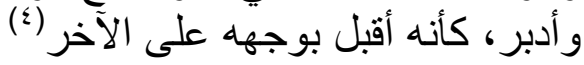
واصطلاحاً: هو كلّ خلافٍ خيّر فيه القارئ بالإتيان بأي وجه كان من الأوجه الجائزة.

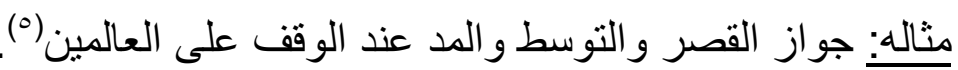

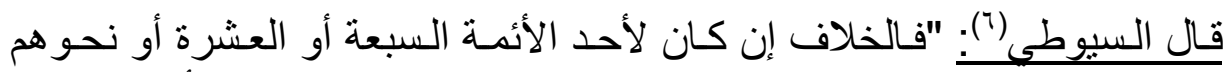

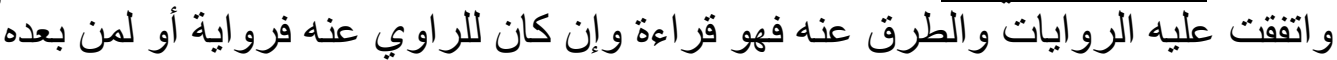

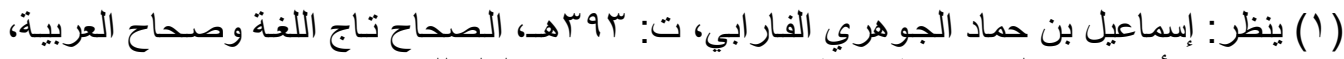

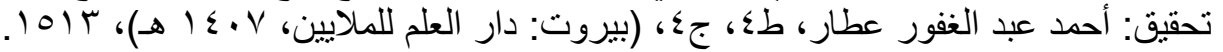

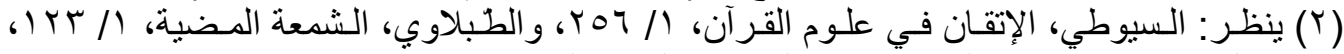

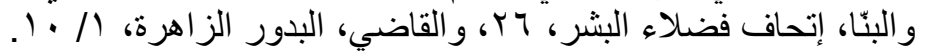

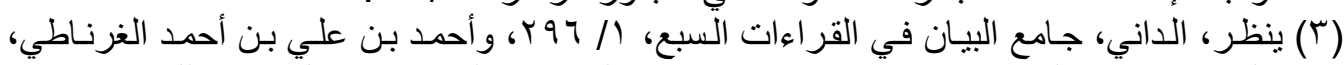

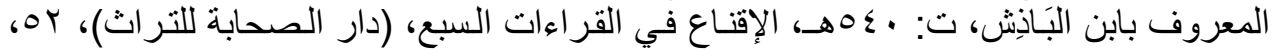

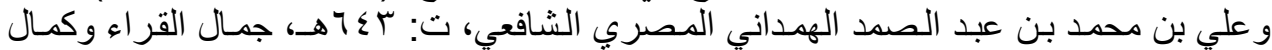

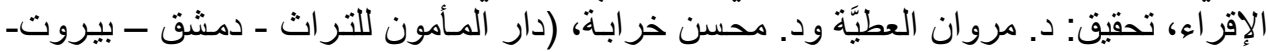

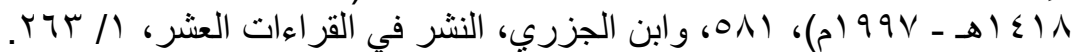

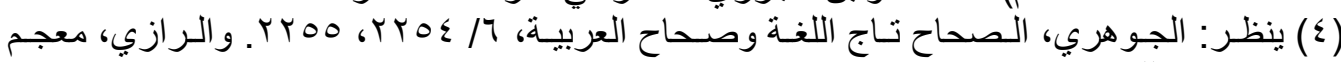

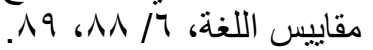

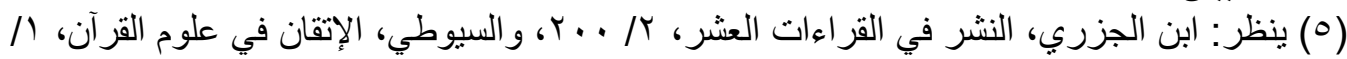

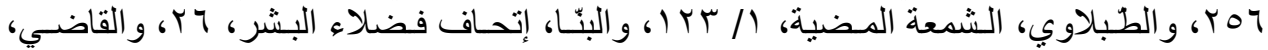

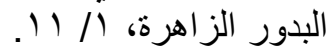

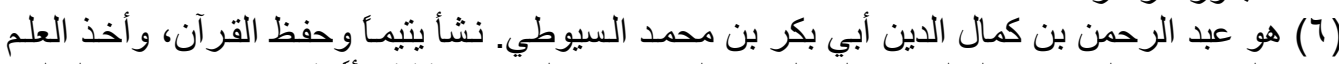

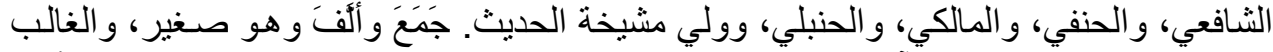

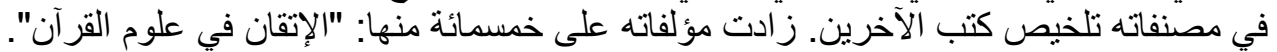

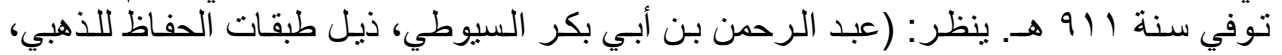

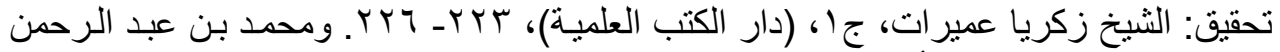

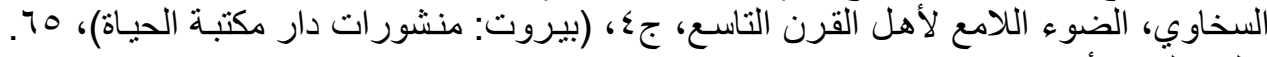


فنـاز لا فطريـق أولا على هذه الصفة ممـا هو راجـع إلى تخيير القـارئ فيـه فوجه" (') (1) (2)

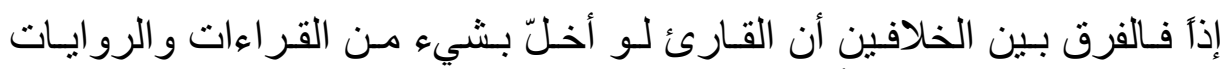

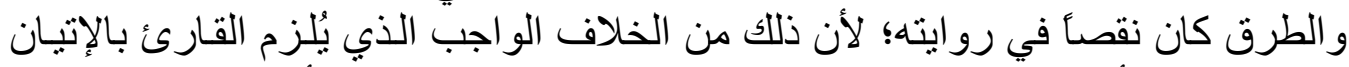

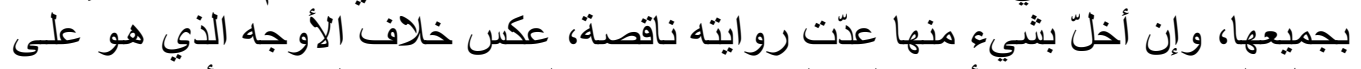

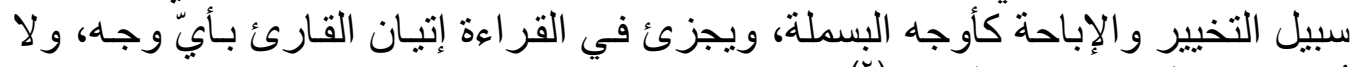

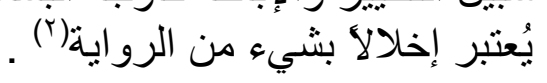

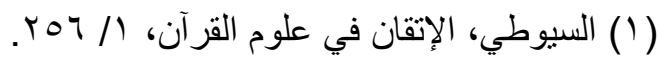

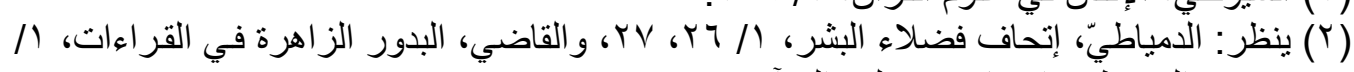

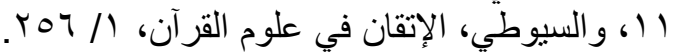




\section{الببمث الثاني \\ الاختلاف في القراءات}

\section{المطلب الأول}

\section{اختناف القراءات في عمد الوحيى(1)}

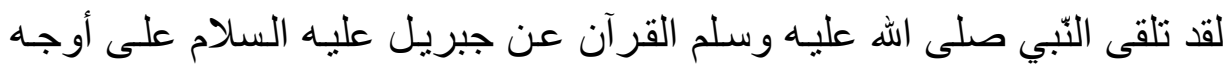

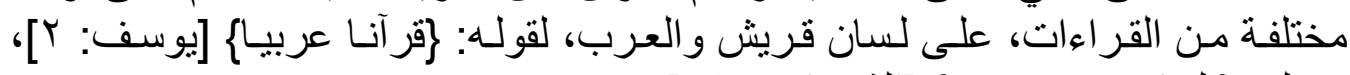

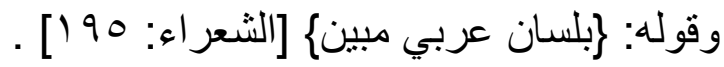

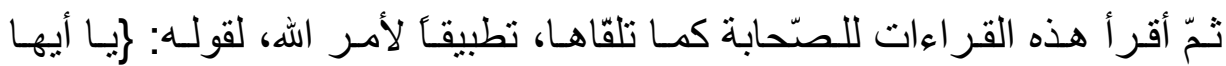

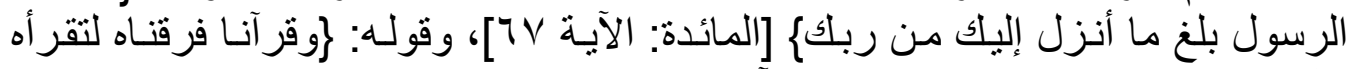

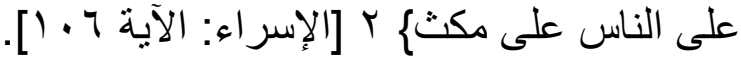

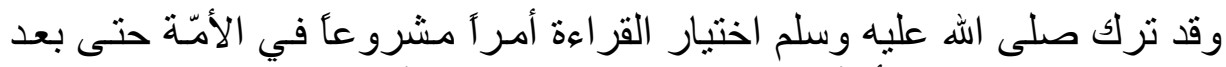

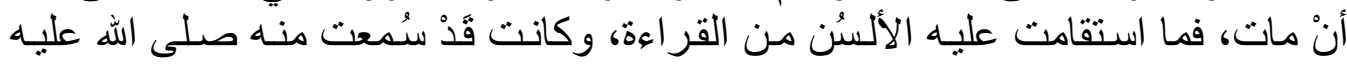

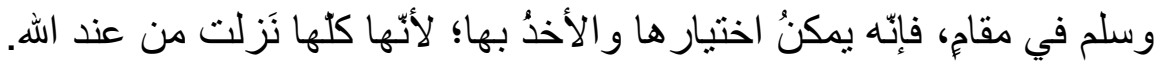

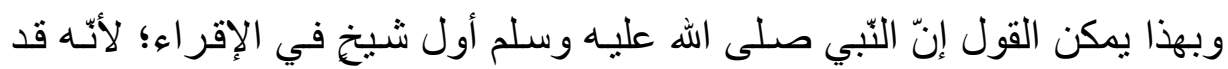

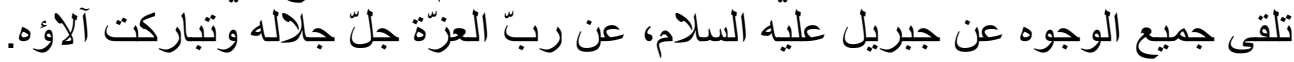

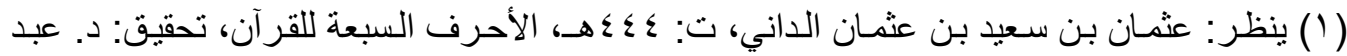

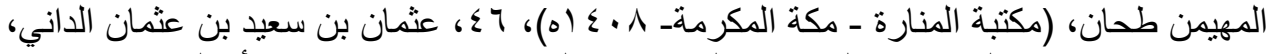

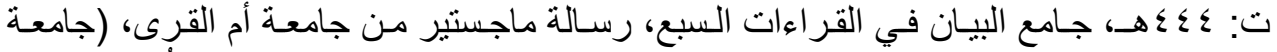

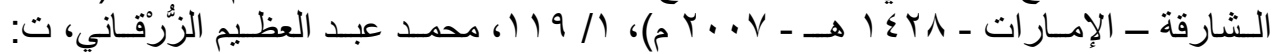

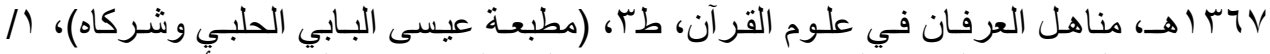

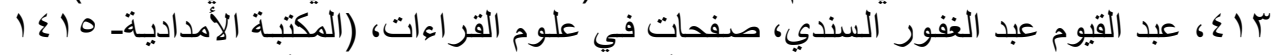

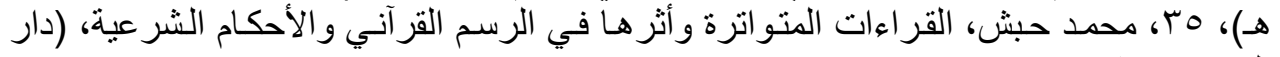

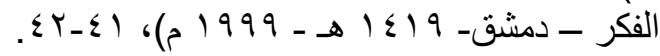




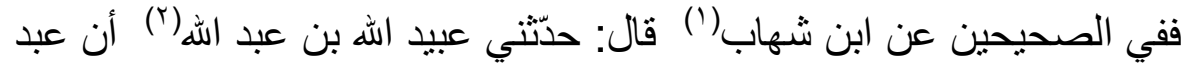

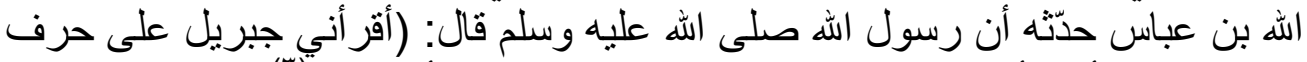

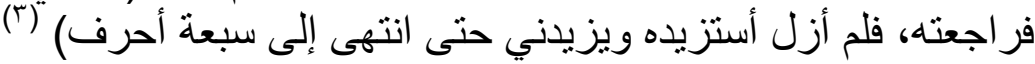

كما أنّ جميع الخلافات التي كانت تنشأ في مسألةٍ من مسائل القر اءة، مباشـرة كان يحسم فيها النّبي صلى الله عليه وسلم ويصوّبها لأحد الوجهين، أو يُقِرِهُهُمَا جميعاً.

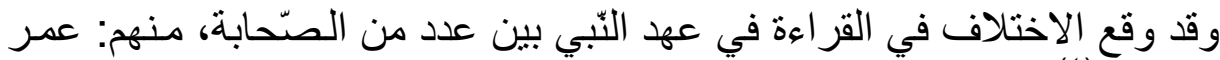

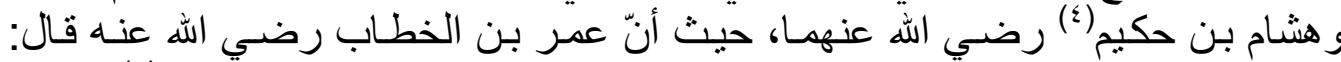

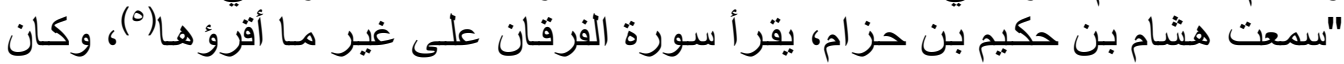

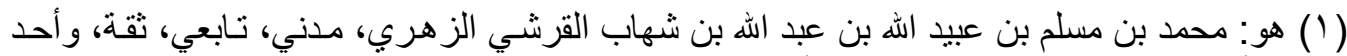

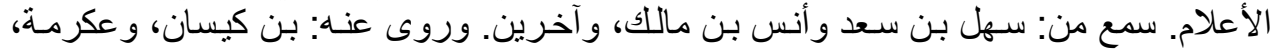

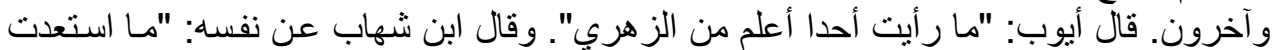

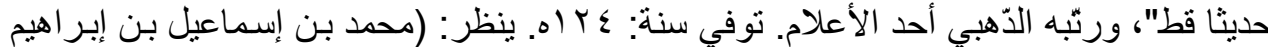

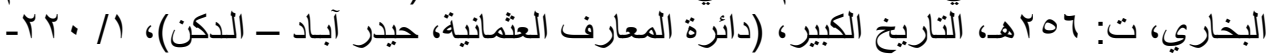

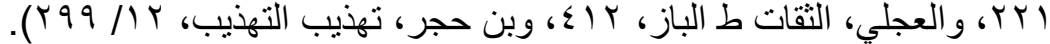

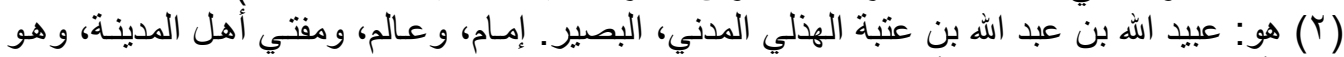

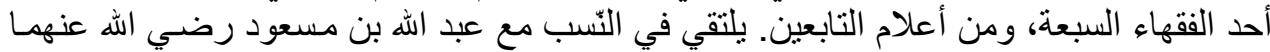

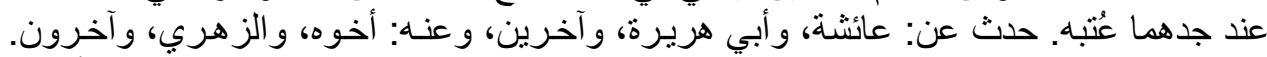

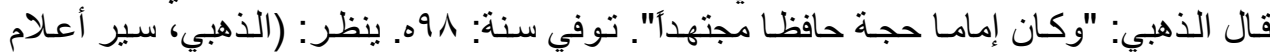

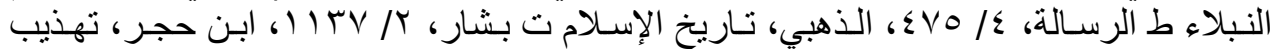

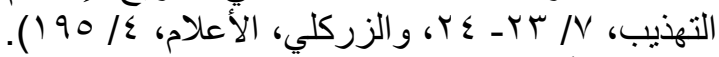

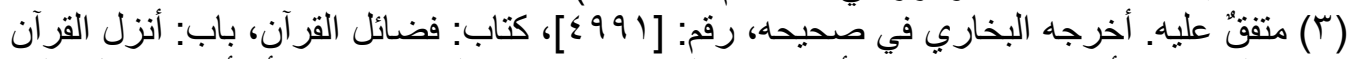

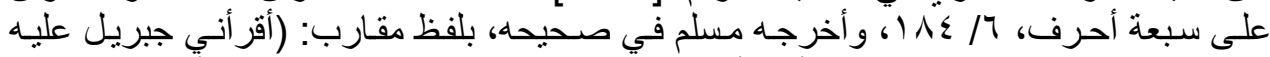

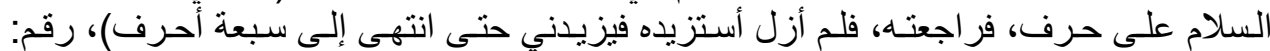
[9/1 (1)]، كتاب: صلاة المسافرين وقصر ها، باب: بيان أن القر آن على سبعة أحرف وبيان معناه، $.071 / 1$

(4) هو: هثام بن حكيم بن حزام بن خويلد بن أسد القرشي الأسدي، وخديجة زوج النبي صلى الله عليه

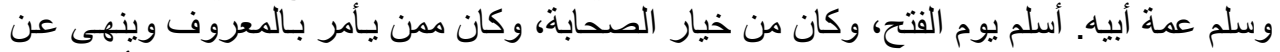

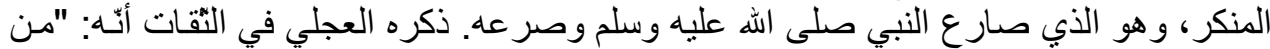

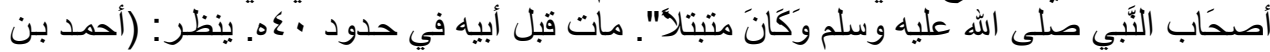

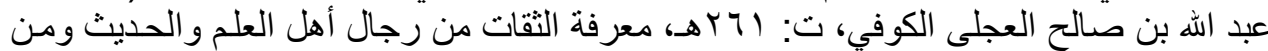

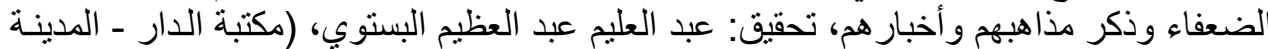

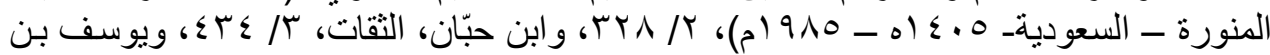

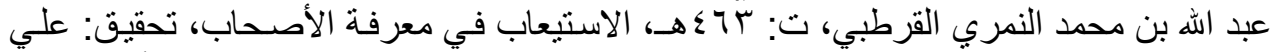

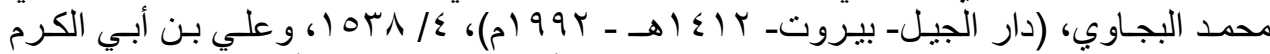

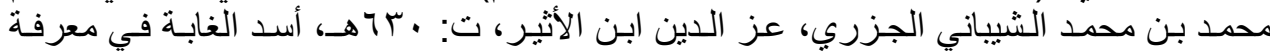

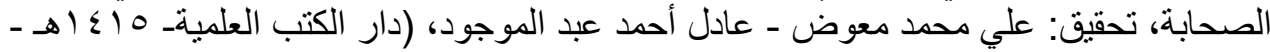

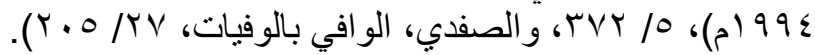

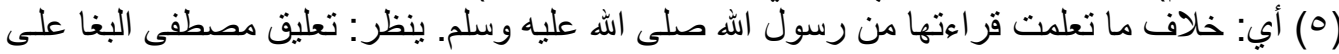




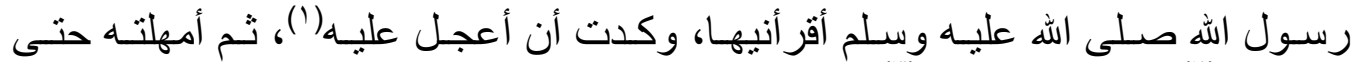

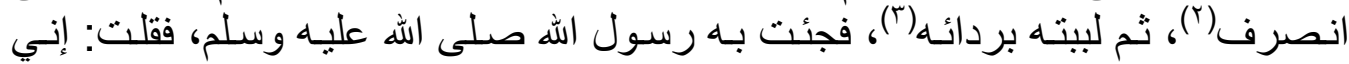

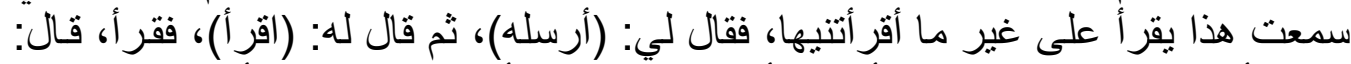

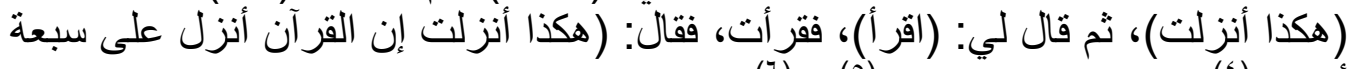

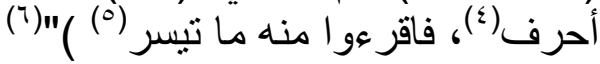

\section{المطll}

\section{افتزاف القراءات في عهد الفلغاء الراشدين}

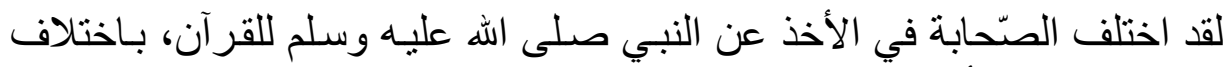

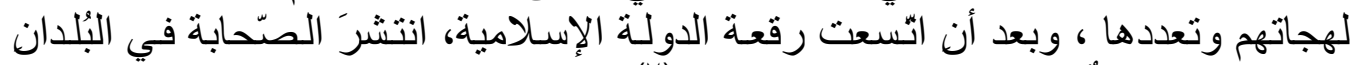

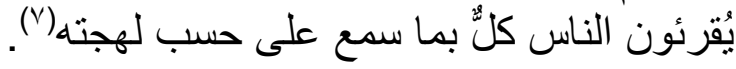

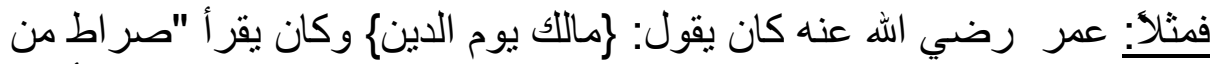

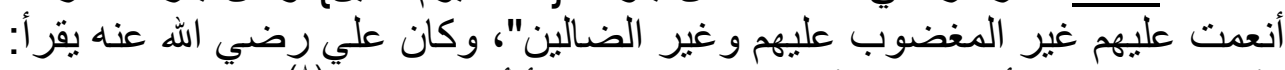

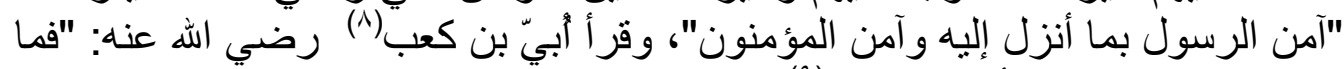

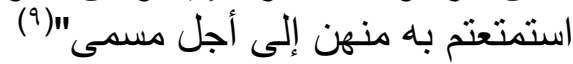

$$
\text { ( (1) أي: في الإنكار و التعرض له. المصدر السابق. }
$$

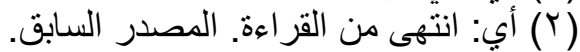

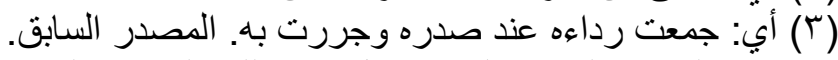

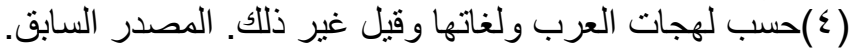

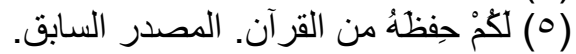

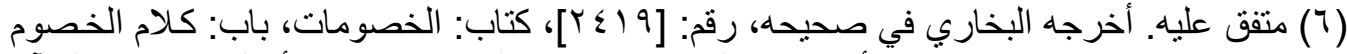

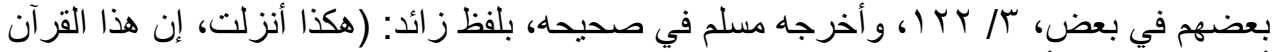

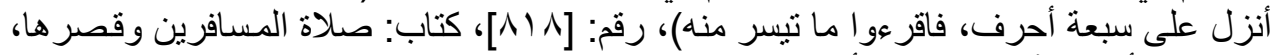

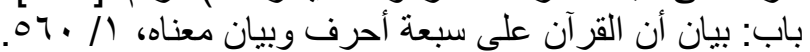

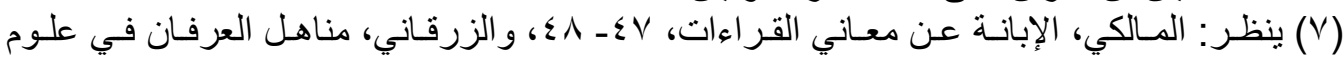

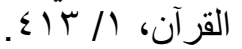

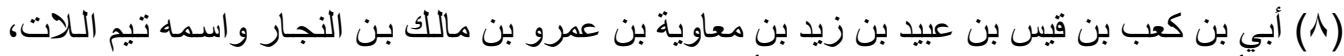

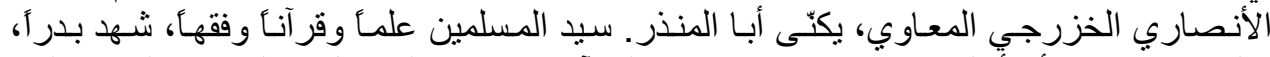

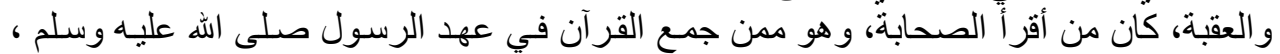

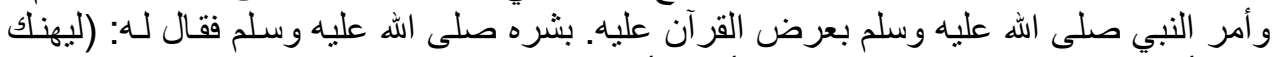

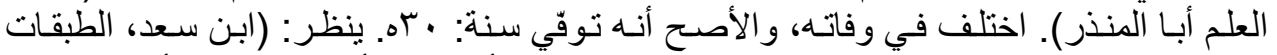

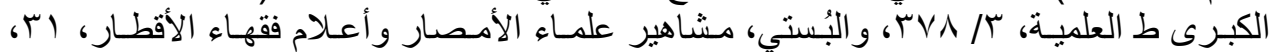

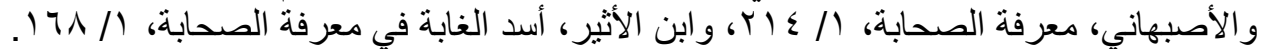

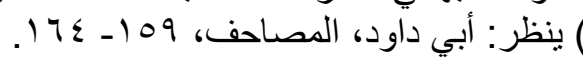




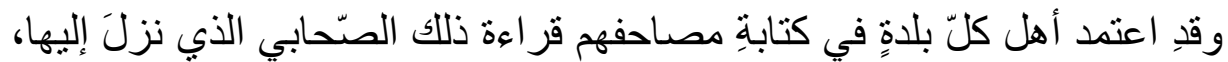

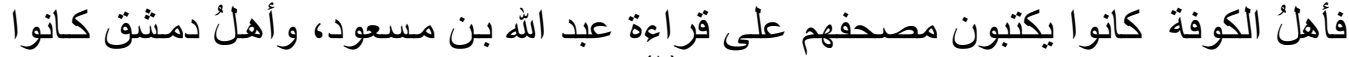

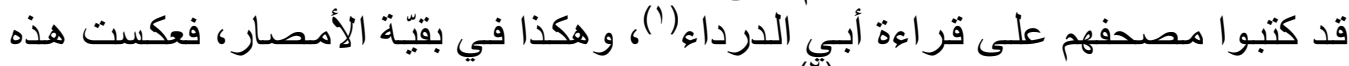

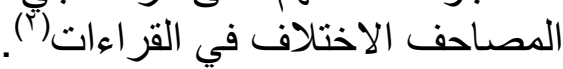

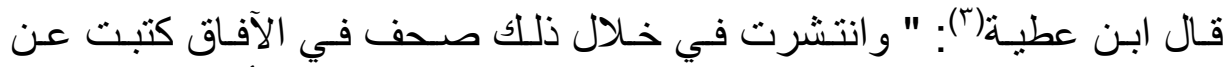

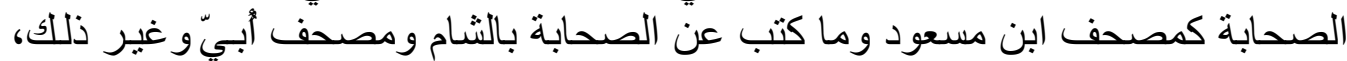

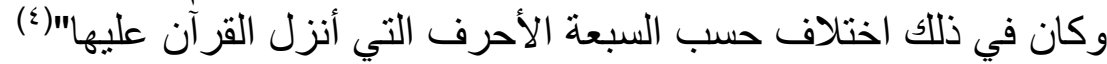

وبعد أن برز اختلاف القراءات في عهد الخلفاء الر اشدين و التهي ظهر أثرهـا

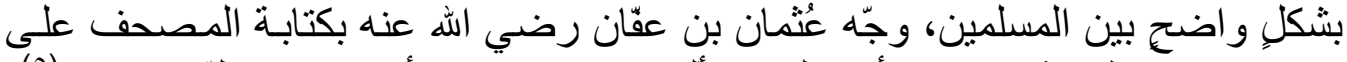

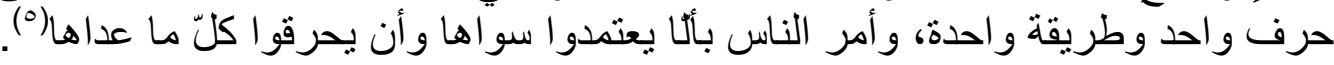

( () هو: عويمر بن زيد بن قيس الأنصاري، أبو الدرداء. الإمام، القدوة، صـاحب رسول الله صلى الله

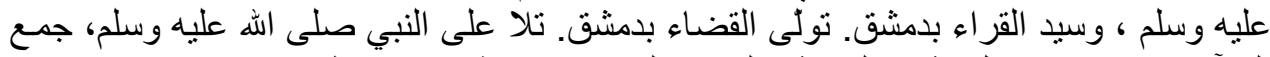

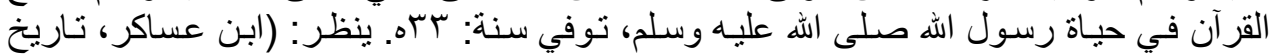

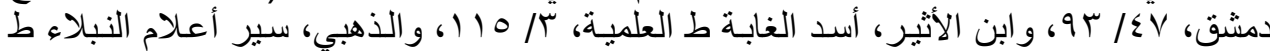

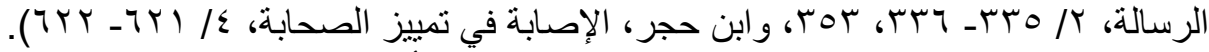

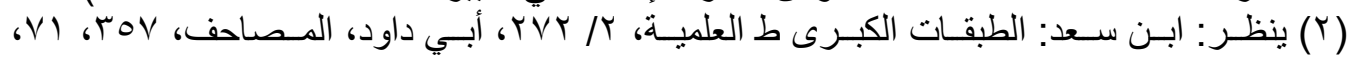

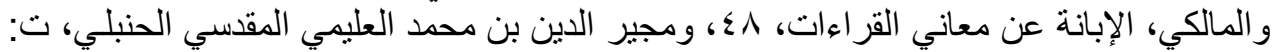

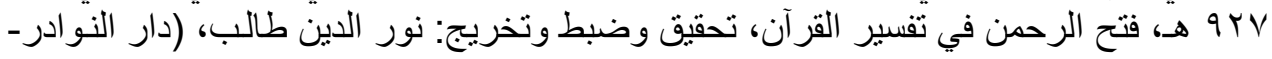
.

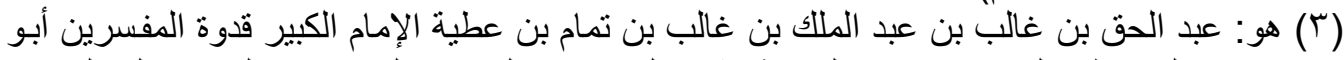

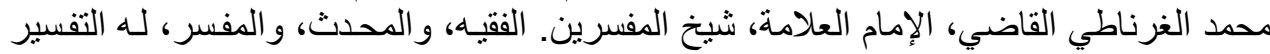

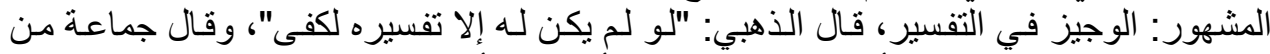

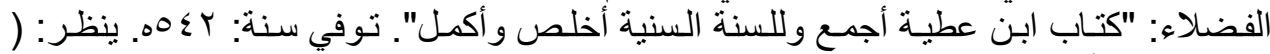

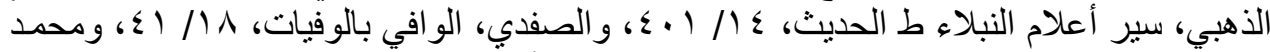

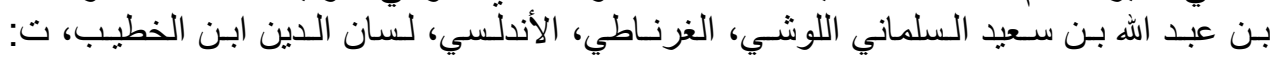

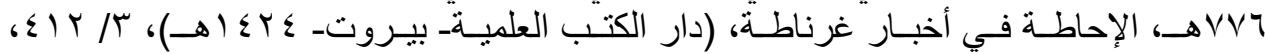

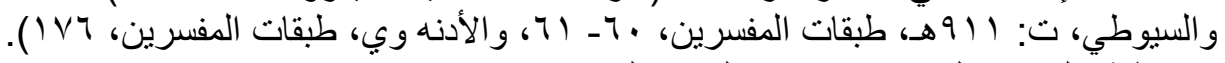

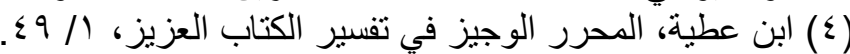

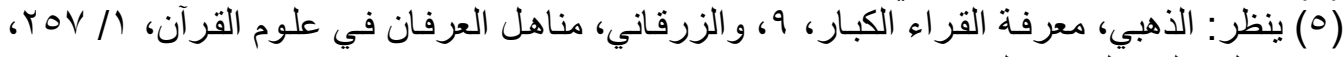


قال عثمان رضي الله عنه: "إذا اختلفتم أنتم وزيد بن ثابت في شيء من فن القرآن،

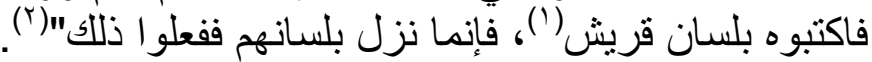

\section{المطالب النغالث}

\section{افتتلاف القراءات في ضوء المماهف المر سلة إلى الأمصار}

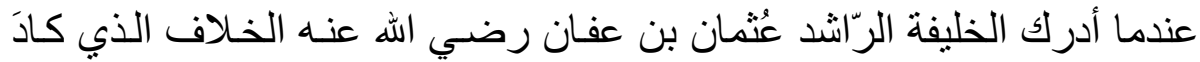

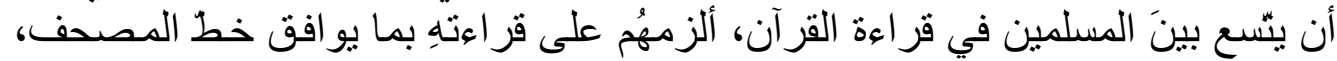

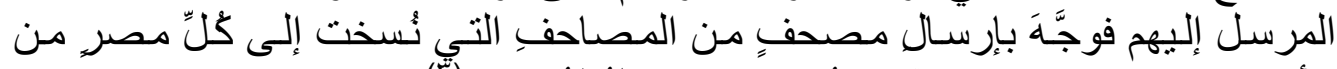

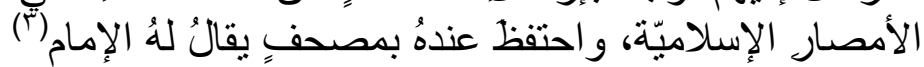

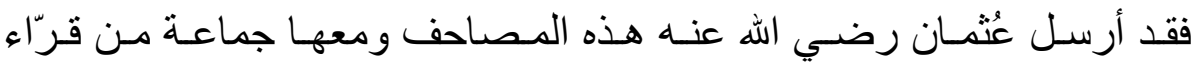

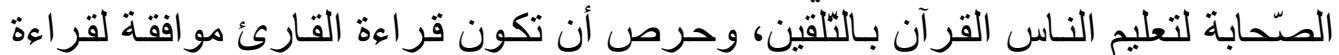

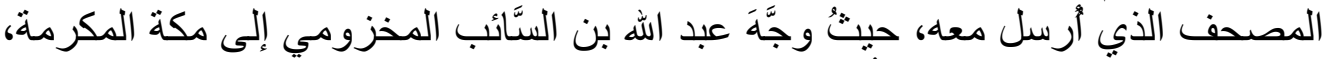

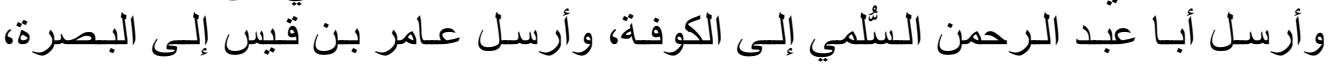

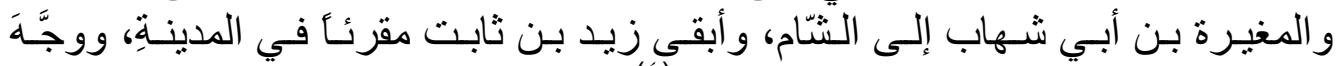

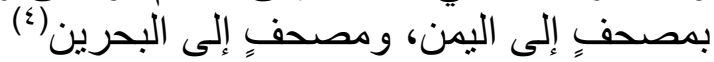

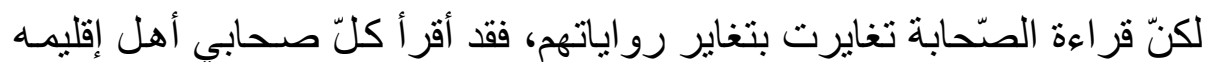

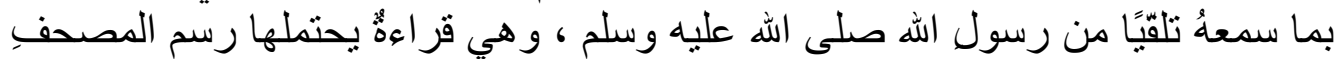

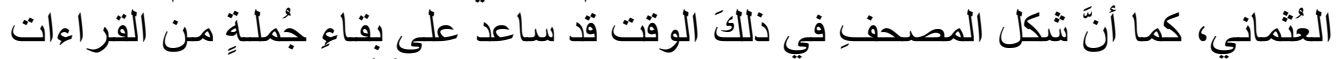

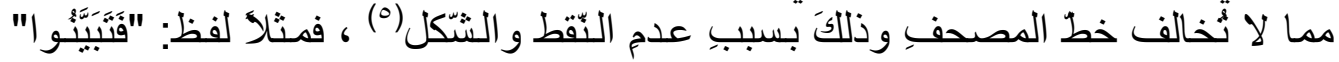

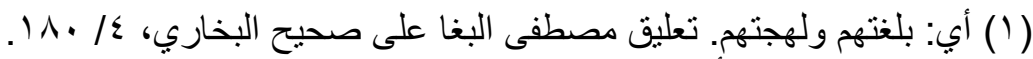

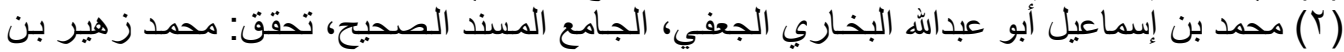

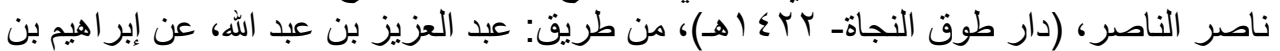

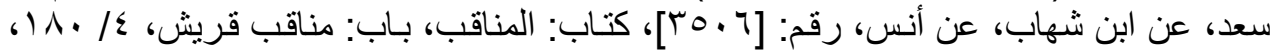

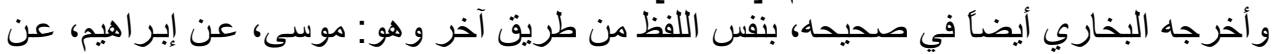

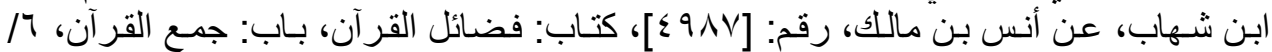

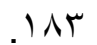
(ז) ينظر: ابن الجزري، النشر في القراءات العشر، // V، والزرقاني: مناهل العرفـان في علوم

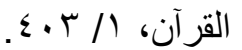

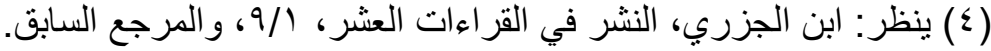

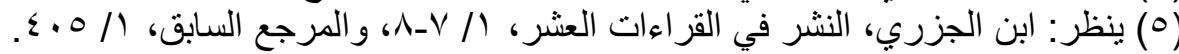




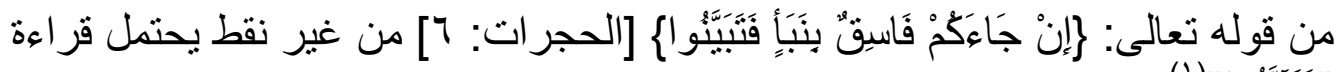

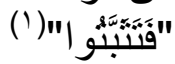

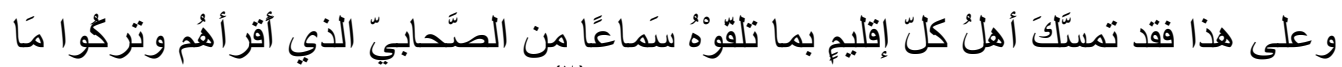

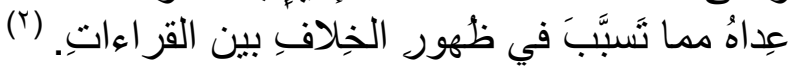

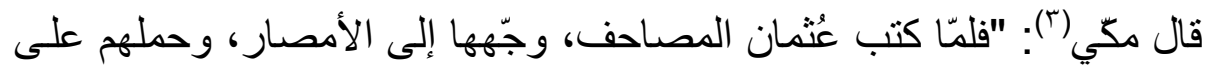

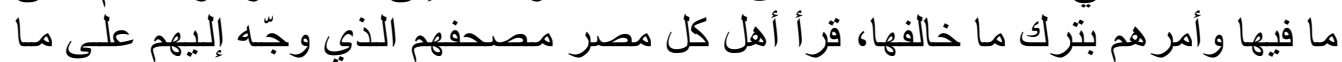

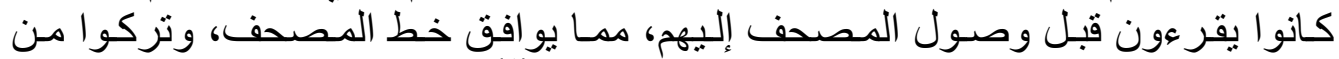

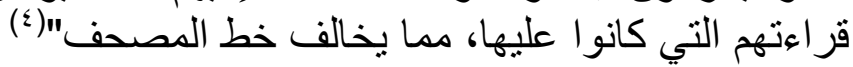

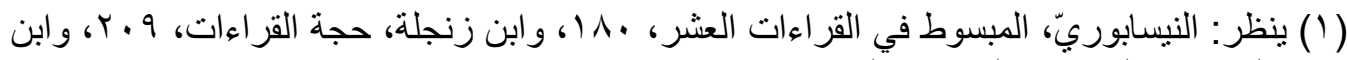

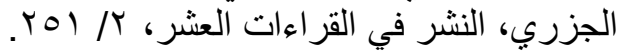

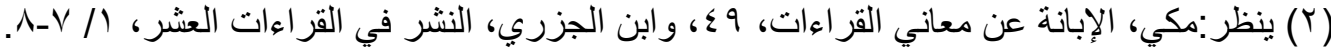

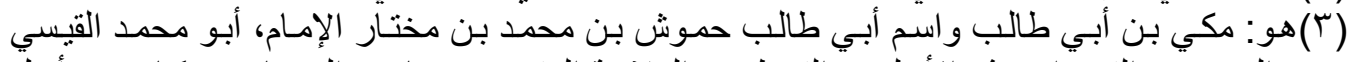

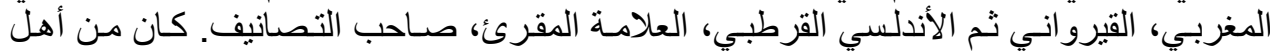

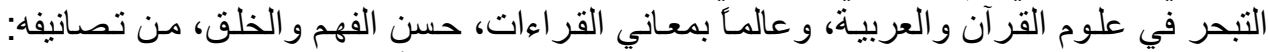

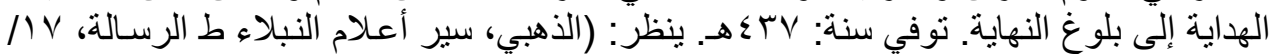

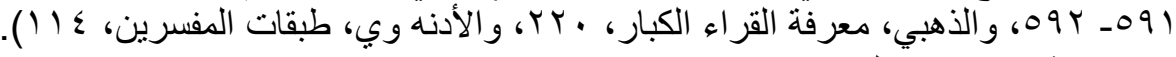




\section{المبهث الثالث}

\section{ملة القراءات بالتفسير}

تتصل القر اءات بالتفسير اتصالّا وثيقًا من حيثُ قبول القراءات، ومن جهة تفسير الآية.

\section{J}

\section{أقسام القراءات مز صيثُ القبول}

ليست كل القراعات يُؤخذُ بها، فمنها ما هو مقبولّ، ومنها ما هو مردود، ومنهـا مـا هو

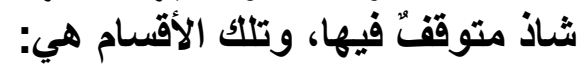
أل/ القر اءة المقبولة و تتقسم إلى قسمين، هما:

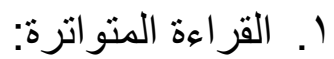

و هي القراءة التي روا اها جمعٌ عن مثلهم إلى منتهاه، لا يمكن تواطؤ هم على الكذب

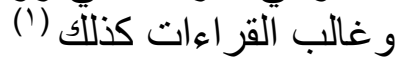

ب. ب القر اعة المثهورة:

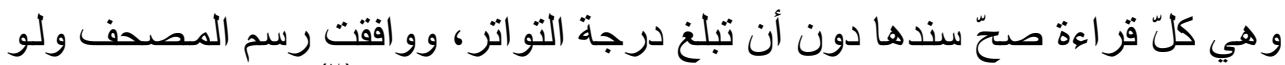

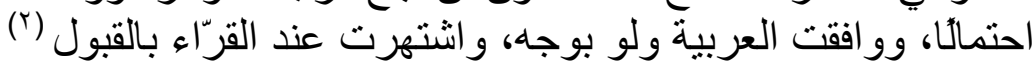

\section{ب/ القر اعة المردودة: وهى تنقسم إلى ثلاثنة أنو اع:}

ا. . القر اءة التي صحّ سندها، وو افقت الرّسم، وخالفت العربية، ولم تتلقّ بالقبول عند

$$
\text { علماء القر اءات. القي }
$$

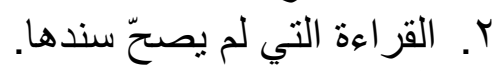

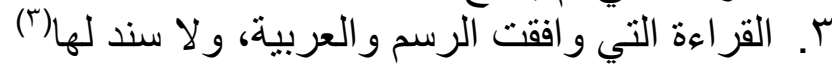

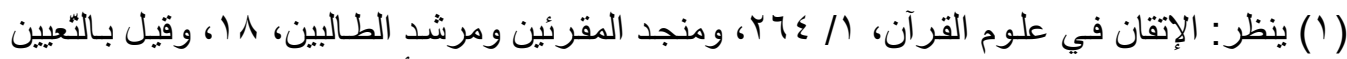

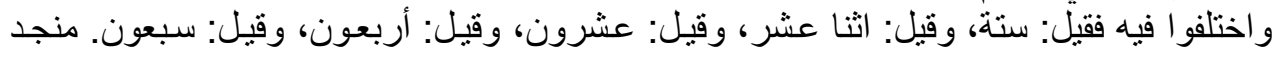

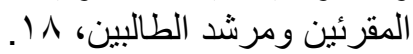

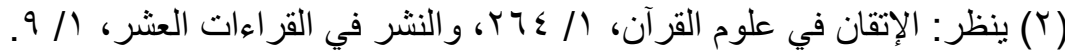

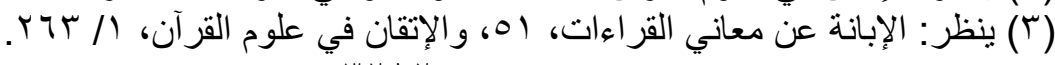




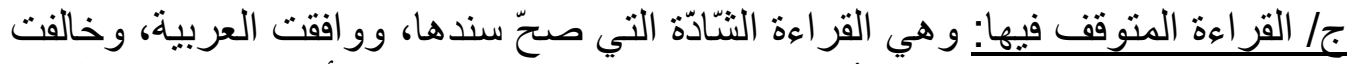

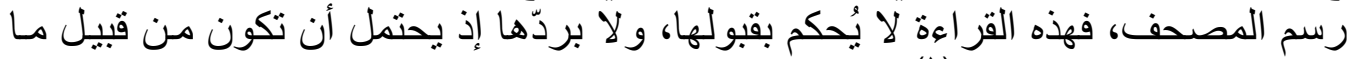

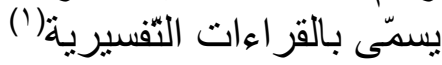

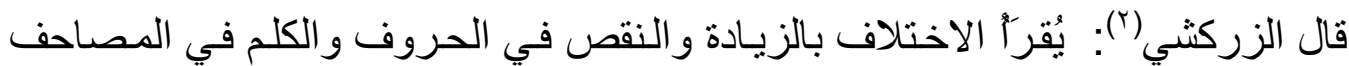

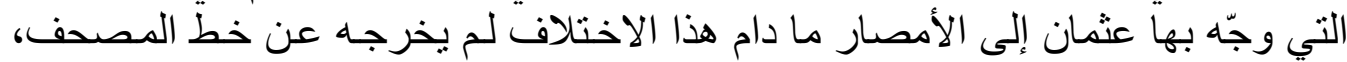

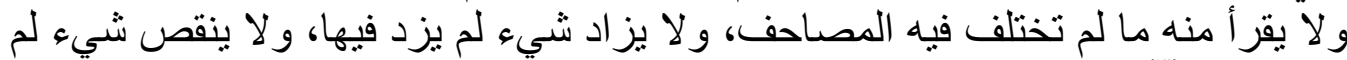

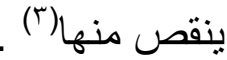

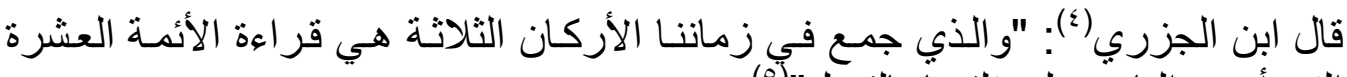

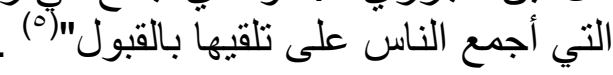

\section{ومدى صلة هذه الأقسام بالتفسير، تكون كالآتي:}

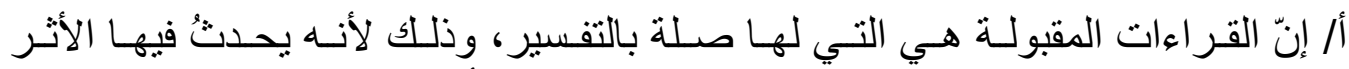

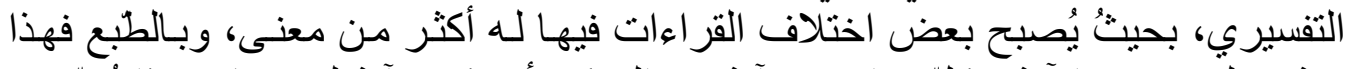

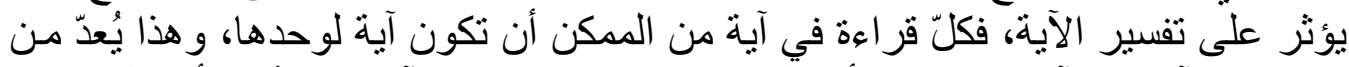

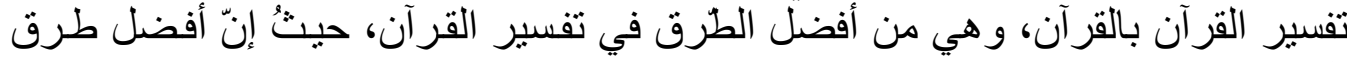

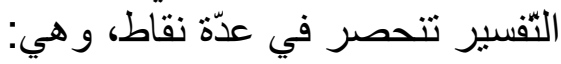

ا - - تفسير القر آن بالقر آن.

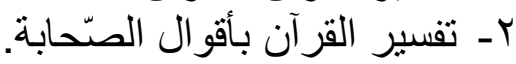

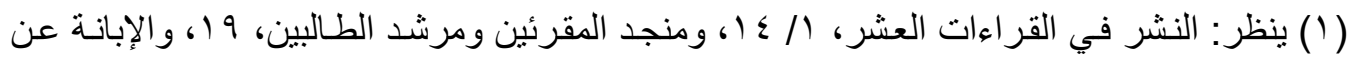

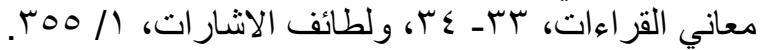

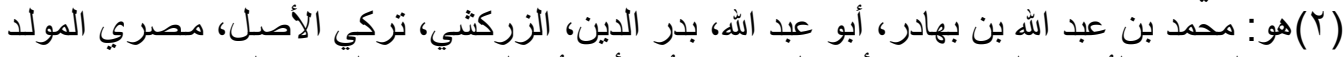

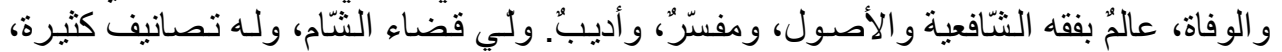

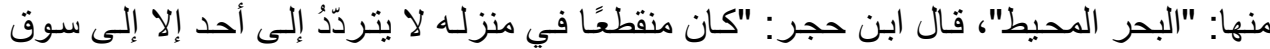

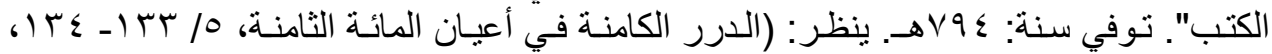

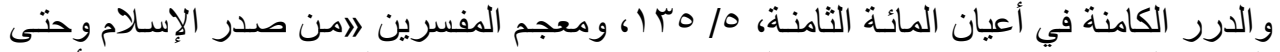

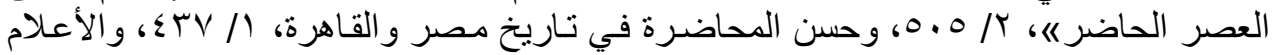

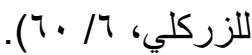

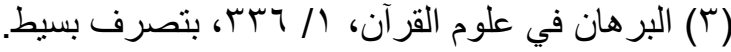

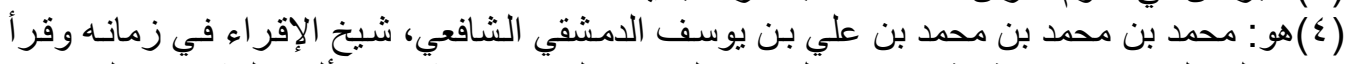

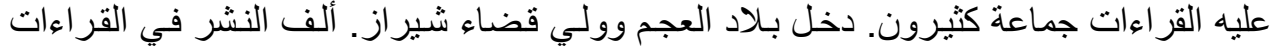

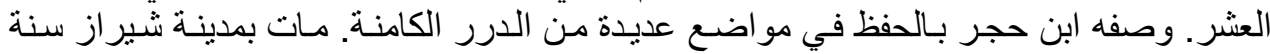

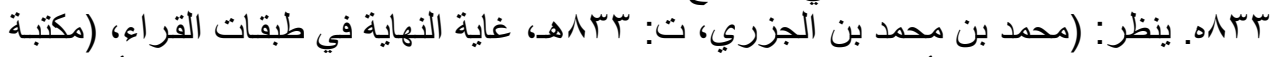

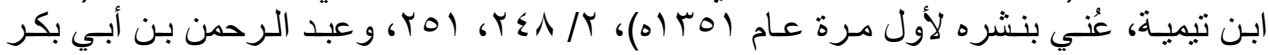

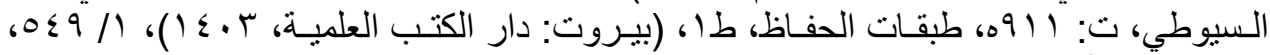

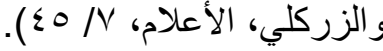




\section{r- تفسير القرآن بأقو ال التابعين، وبلغة العرب(') .}

ب/ إنّ القراءات المردودة لا يوجد بها أثر تفسيري، وولا علاقة لها بالتفسير.

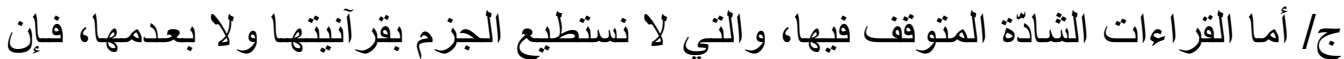

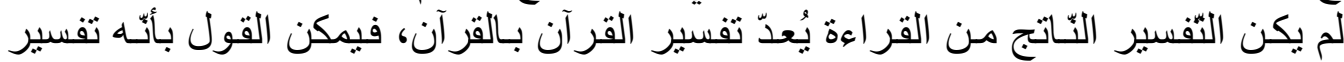

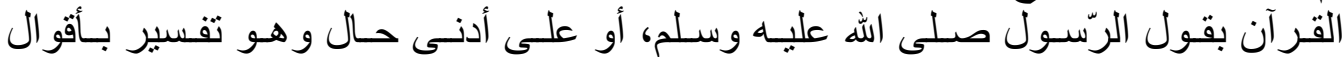

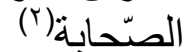

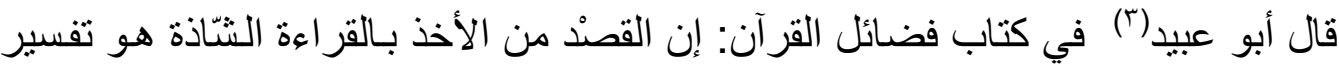

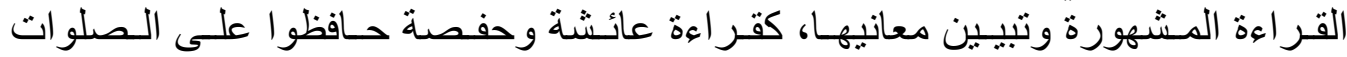

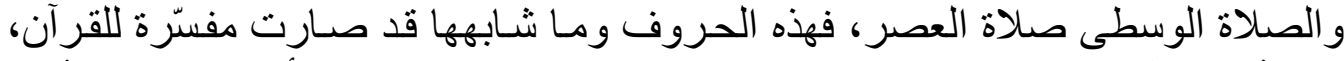

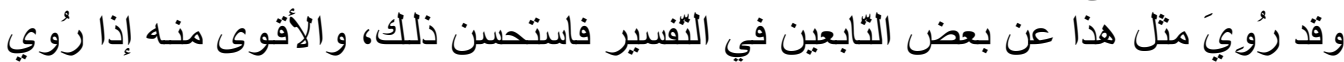

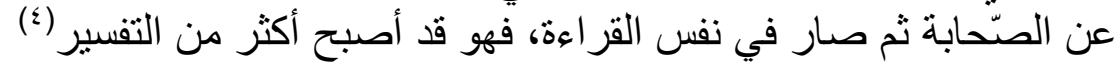

\section{1المطلب الثناني}

\section{أقسام القراءات من جهة التنهنسبر}

ليست كلّ القر اءات لها تعلّقُ بالثقفير، فهي لها حالتين: إحداهما ليس لها تعلق بالتفسير، والثانية لها تعلق بالتفسير من عدّة جهات.

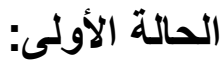

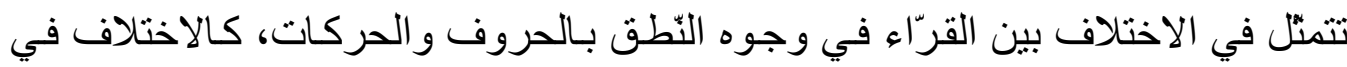

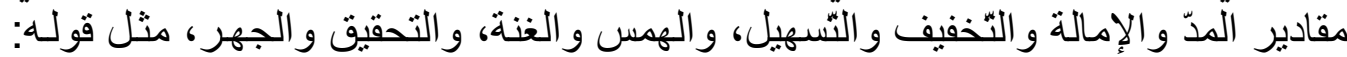

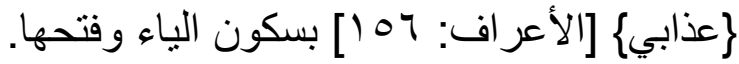

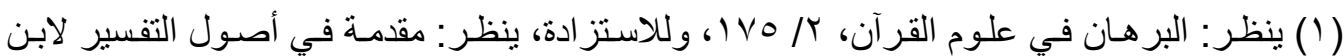

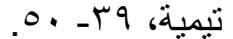

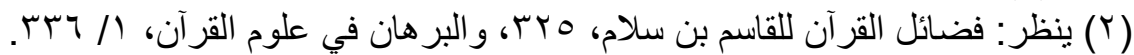

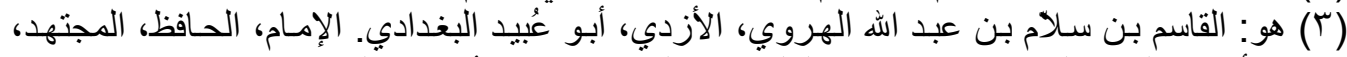

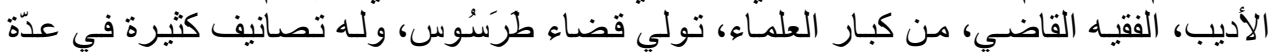

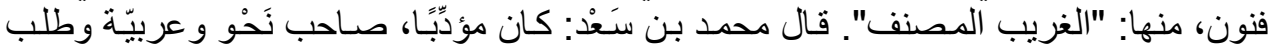

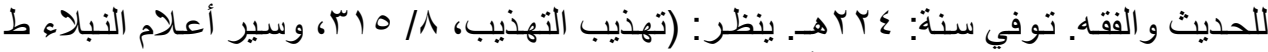

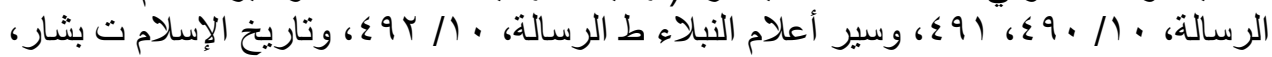

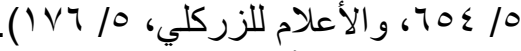

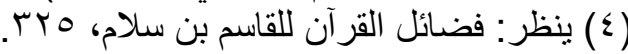




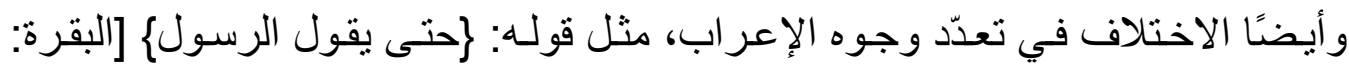

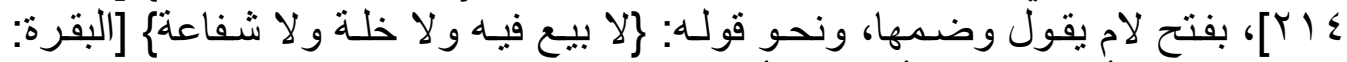

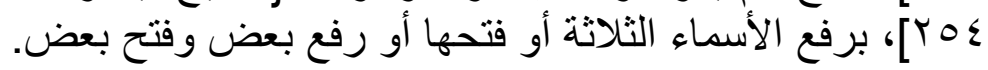

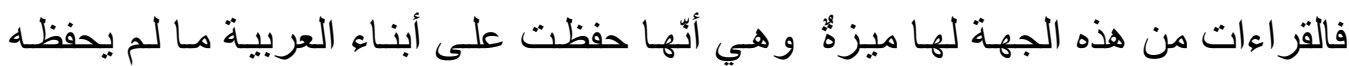

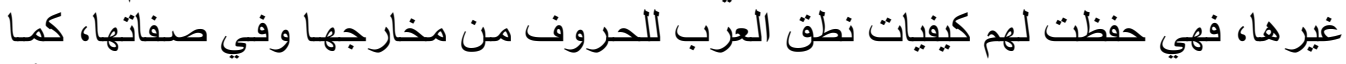

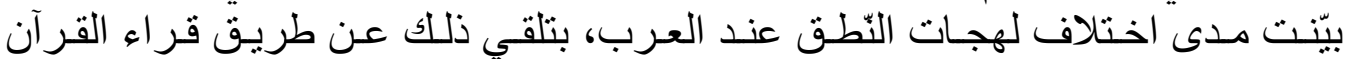

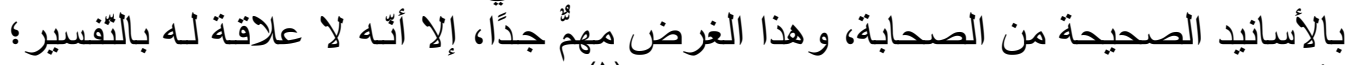

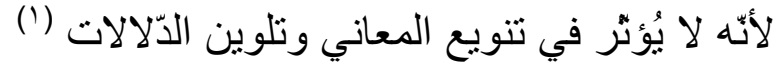

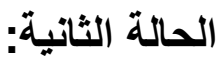

و هي الاختلاف بين القراء في حروف الكلمـات، مثل قولـه: (مالك يوم الدّينئ [الفاتحة:

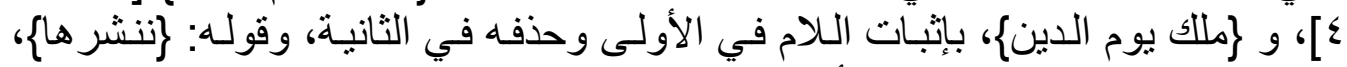

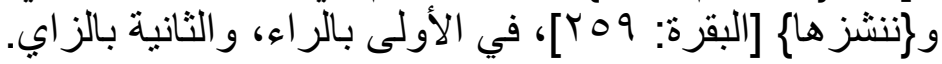

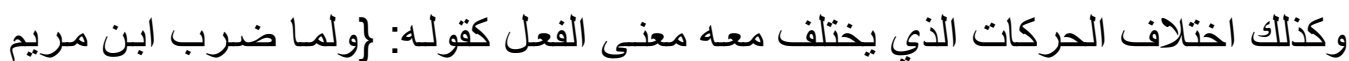

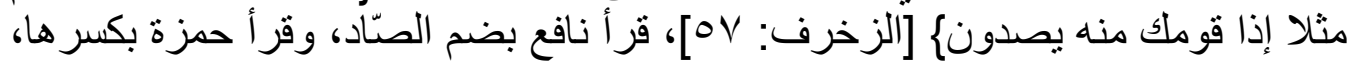

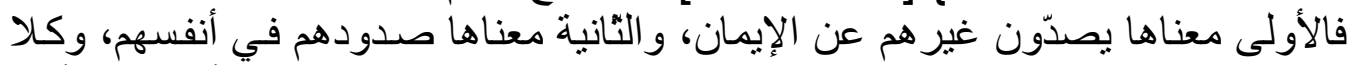

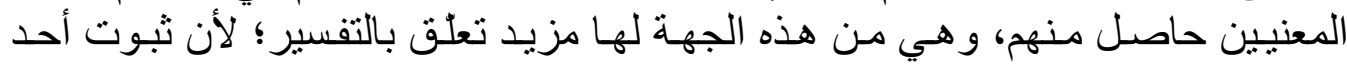

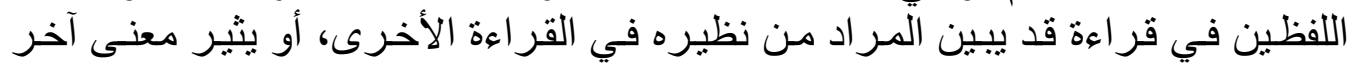
غيره.

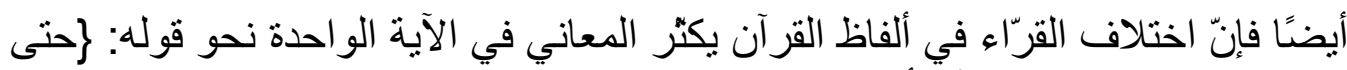

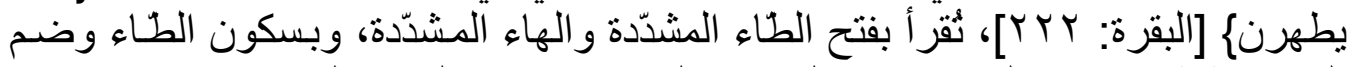

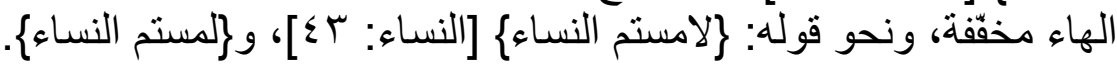

إددا متى ما وقع الاختلاف في القراءة على وجهين فأكثر، أصبحت المعاني أكثر؛ لاحتمال

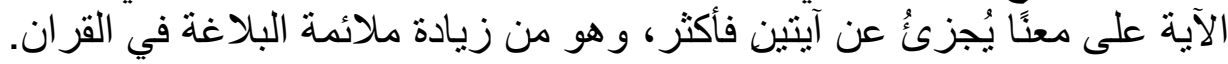




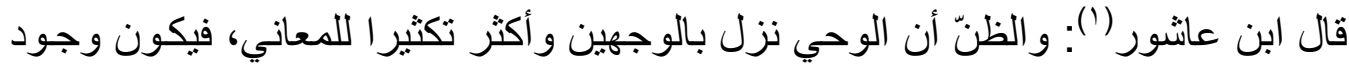

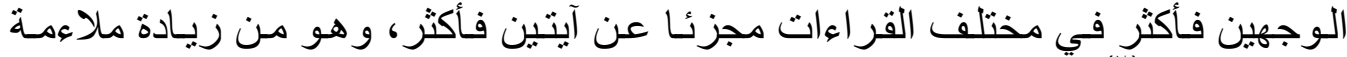

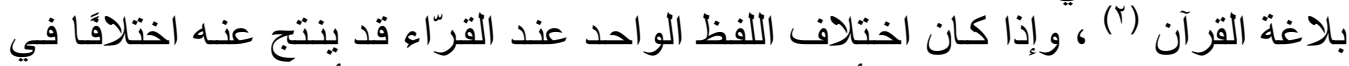

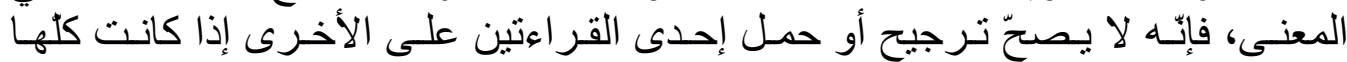
متو اترة")

وقال أبو جعفر النحّاس(؛): "الديانة تحظر الطعن على القراعة التي قر أ بها الجماعـة، و لا

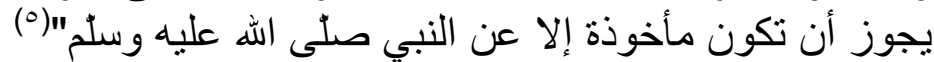

\section{المطلب الثالث}

\section{نوع 1الافتلاف الواقه بيزن القراءات}

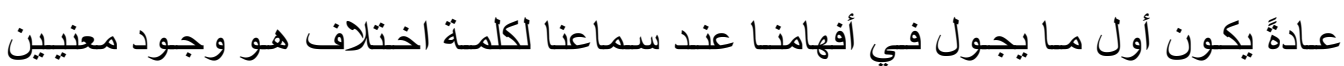

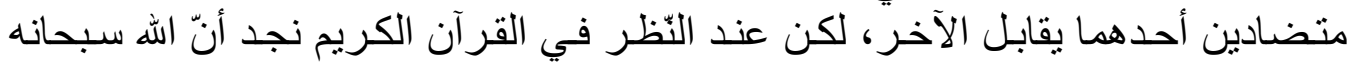

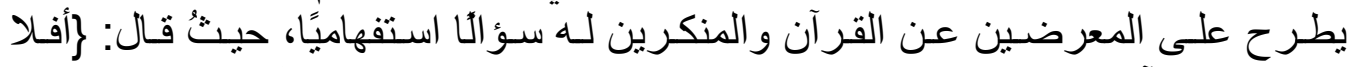

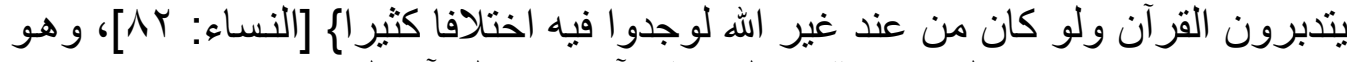

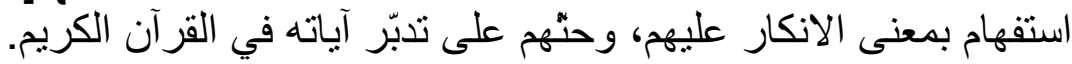

ومعنى ذلك:

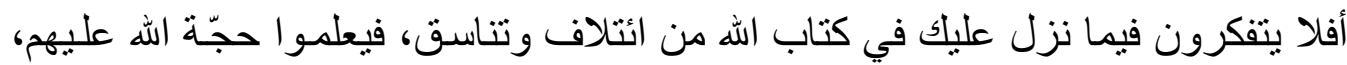

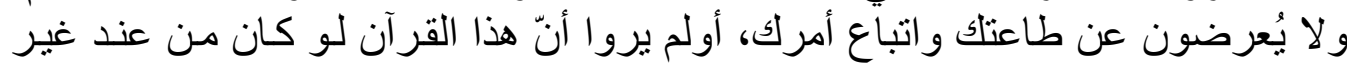

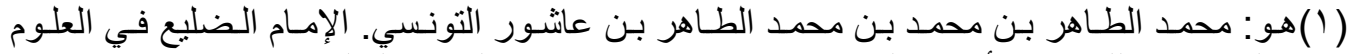

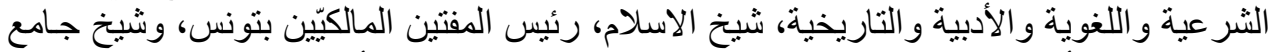

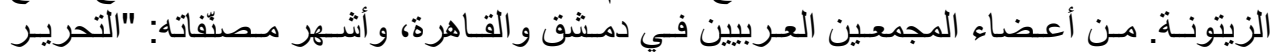

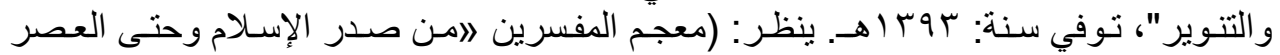

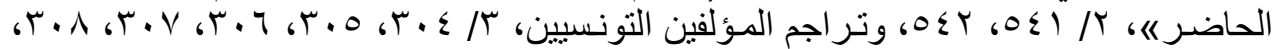

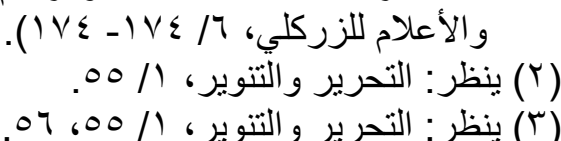

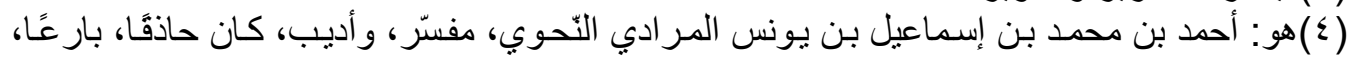

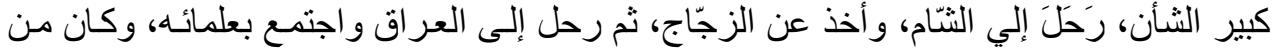

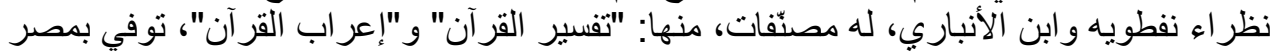

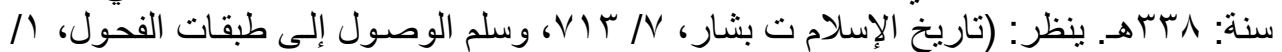

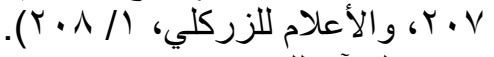

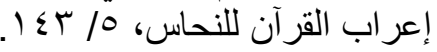


الله لوجدو ا فيه تفاونَّا وتناقضيًا كثيرًا؟؟ وذللك لا يظهر إلا لمن تدبّره و تأمّلـه، وليس لمن

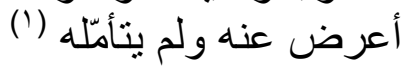

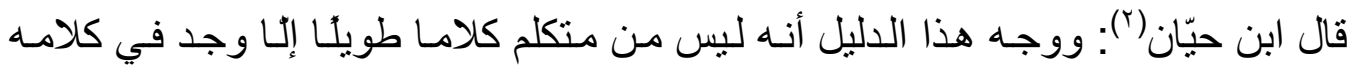

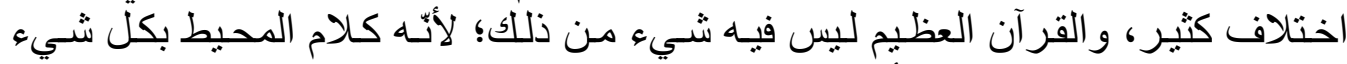

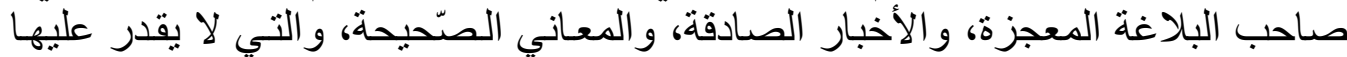
إلا العالم بما لا يعلمه أحد سو اه(")

إدذا فكيف يمكنتـا أن نجمـع بين الأمـرين مـن الاختلاف و وعدمهـ بمـا يتو افق مـع القرآن وتستو عبه عقولنا؟

فالجواب هو: إنّ الاختلاف ينقسم إلى قسمين: الأول: اختلاف تضناد. الثاني: اختلاف تغاير وتنوع.

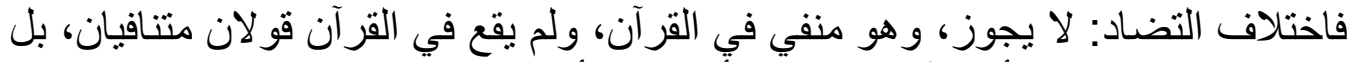

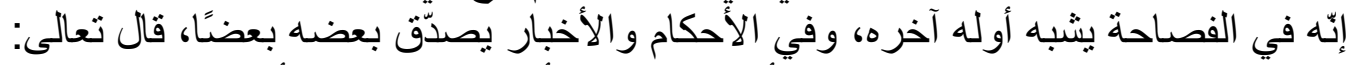

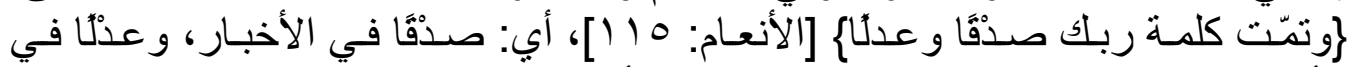

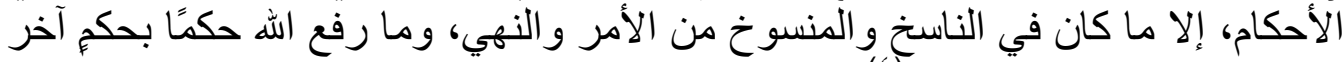
إلا وله سبحانه حكمة في ذللكان في الأن

أمّا اختلاف الثّغاير والثنّوع : فهو جائز، فهو المقصود بـه عند ذكر اختلاف القراءات، ويقع بين القراءات و التفسير و غيرها

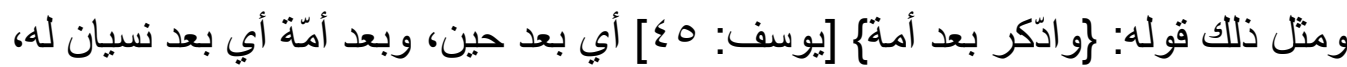

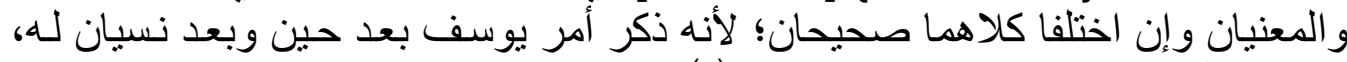

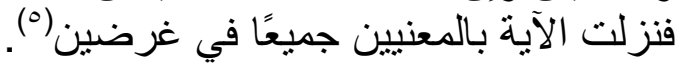

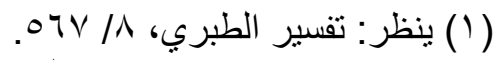

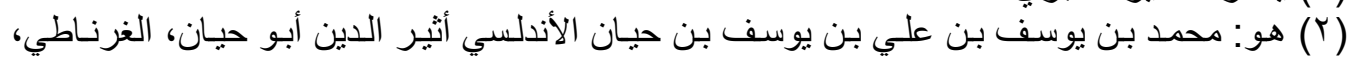

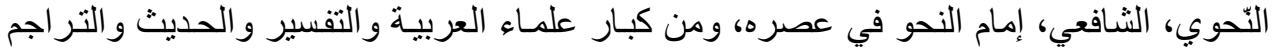

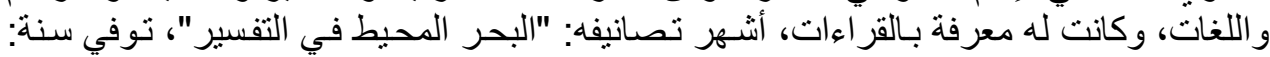

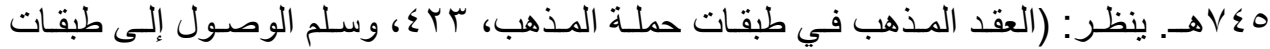

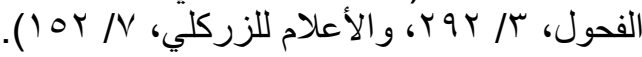

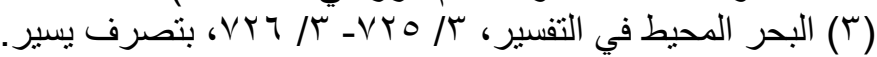

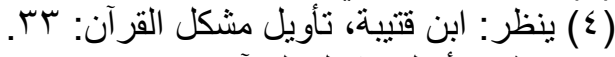


إدًا فاختلاف القر اءات يُعدّ اختلاف تغاير وتتوع لا اختلاف تناقضر وتضاد .

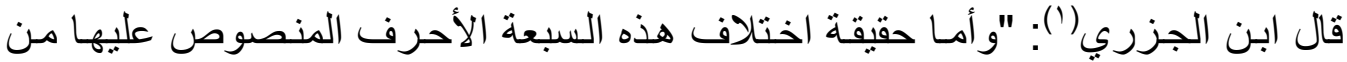

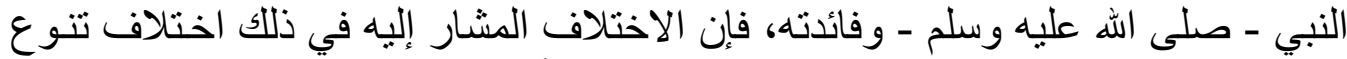

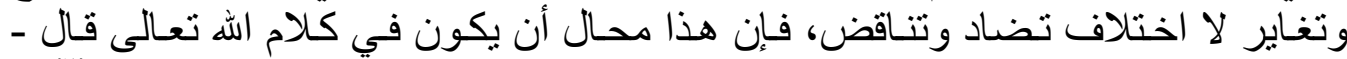

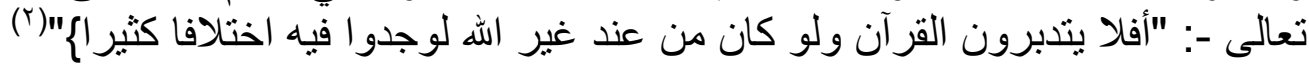

\section{وذكر العلماء أن اختلاف القراءات لا يخلوا من ثلاثة أحوال، هي:}

1ـ اختلاف اللفظِ و اتُحادُ المعنى، بأن يكونَ في أحدِ الكلمنين زيادةٌ في المبنى. كأن تكون في القر اءة زيادة ألفٍ، ومنه قوله: (نخرةج [ النازعات: (1)]، بدون ألفٍ،

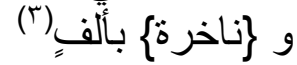

أو تكون فيها زيادة تضعيفٍ، وذللك مثل: قوله

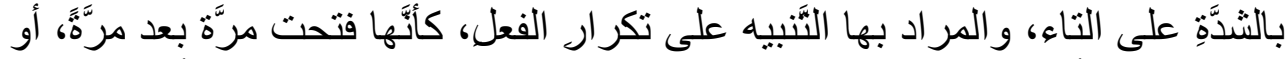

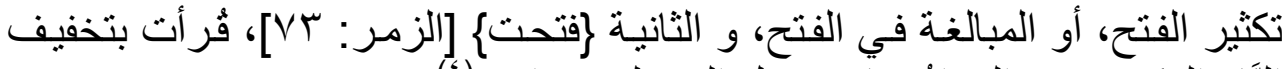

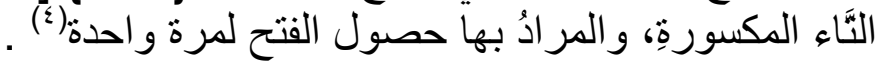
r- اختلاف اللفظ واختلاف المعنى، مع جواز اجتماعهما في شيء واحد.

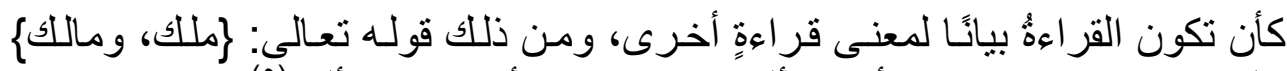

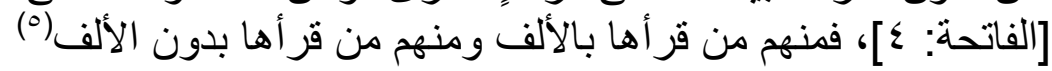

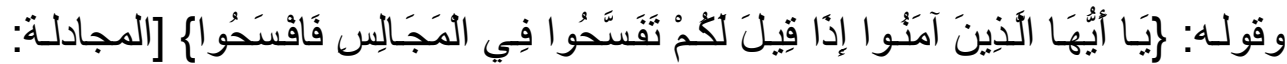

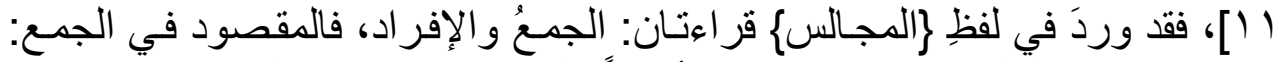

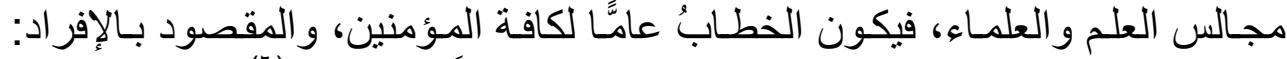

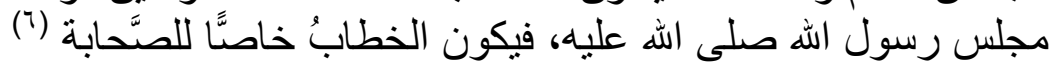

ب- الاختلاف الكلي للفظ و المعنى، فيكون معنى كلّ قر اعة بمنزلـة آيـة مستقلة، وهذا الأمر' لا يخلو من حالين:

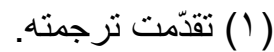

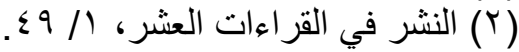

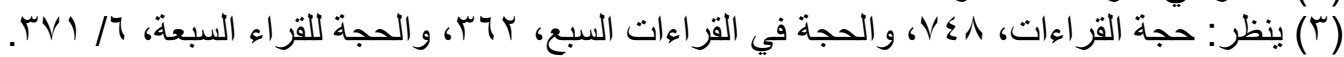

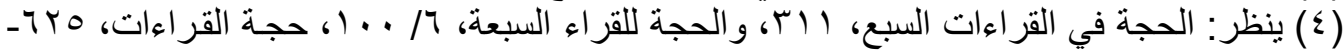
7ry

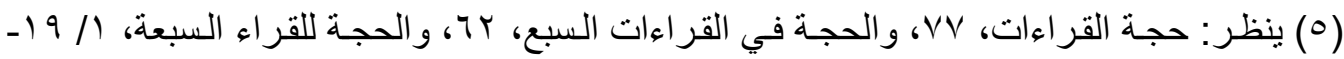

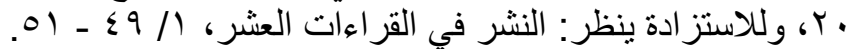

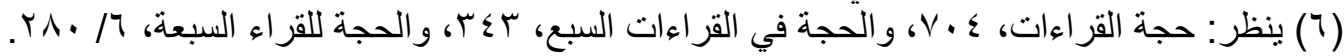


الأول: أن يكونَ اختلافُ القر اءة راجعًا إلى ذاتٍ و احدةٍ، فيكونُ حُكمًا لهذه الذات

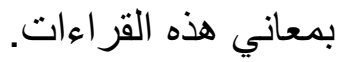

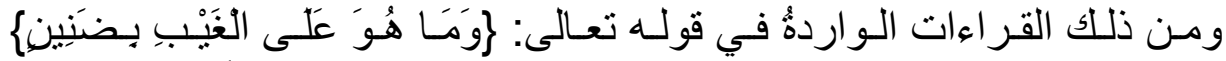

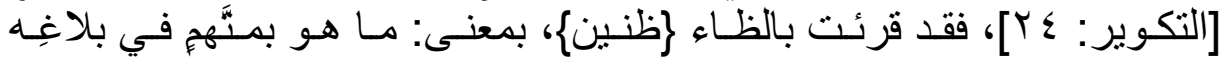

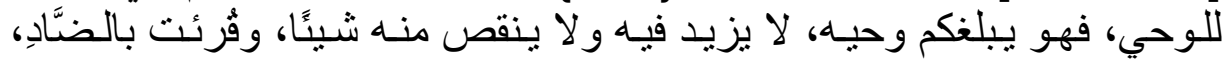

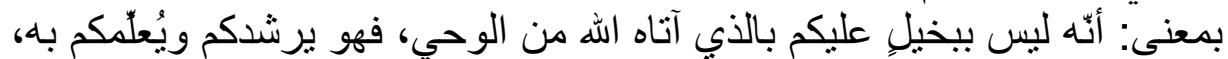

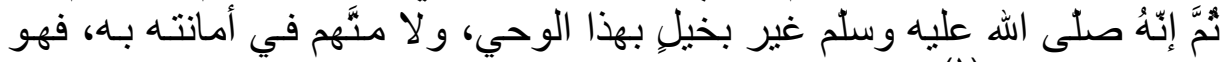
يؤديه كما سمعاه (')

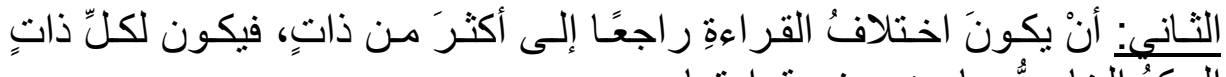

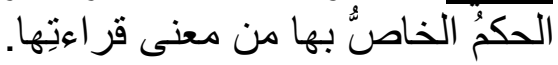

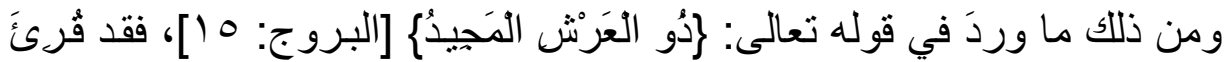

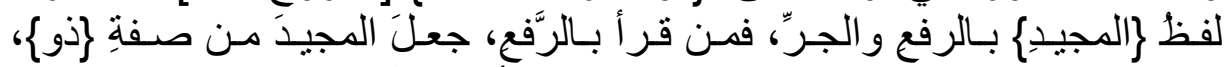

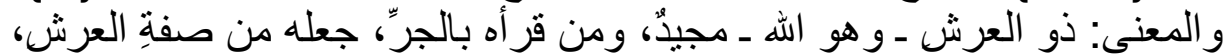

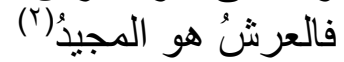

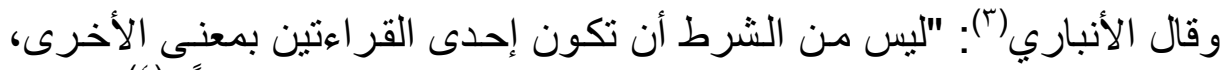

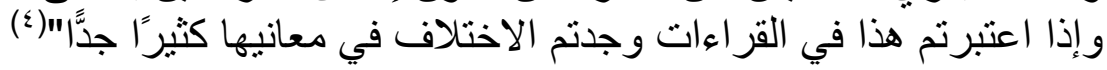

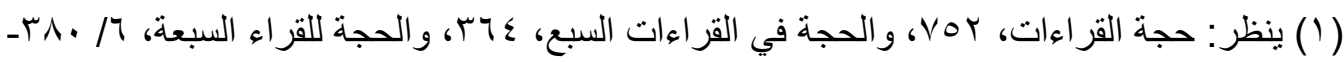
rNi

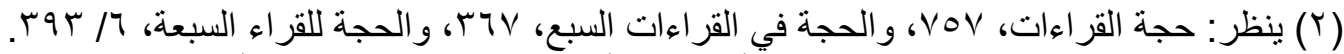

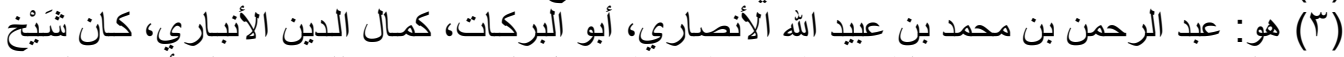

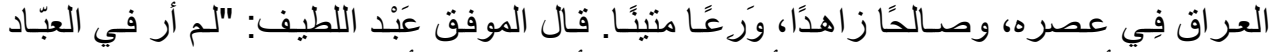

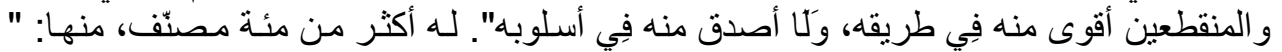

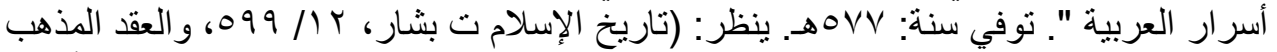

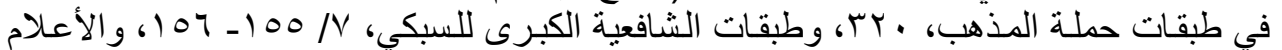

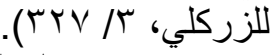

( الإنصاف في مسائل الخلاف بين النحويين البصريين و الكوفيين، / / ابץ. 


\section{المطلب الرابـ}

\section{الهكهة من افتناف القراءاتت}

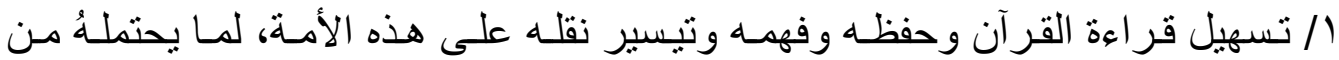

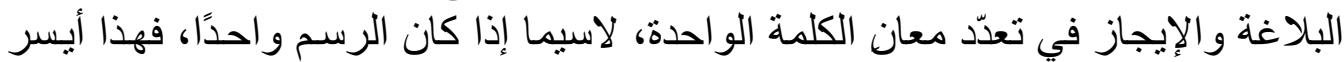

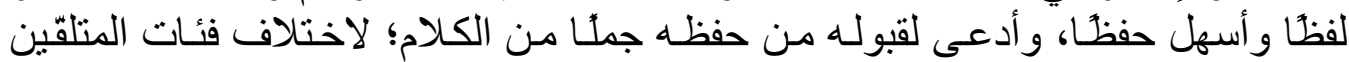

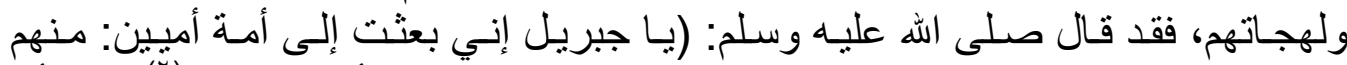

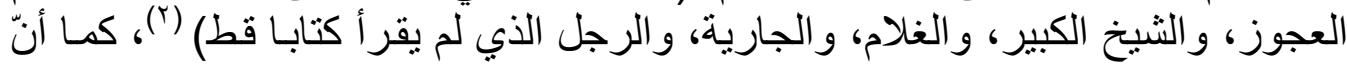

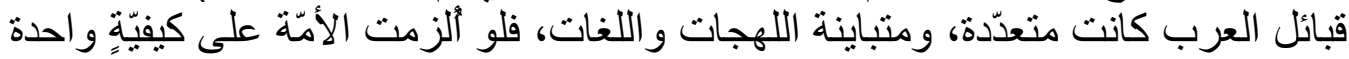

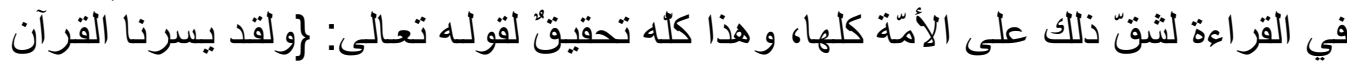

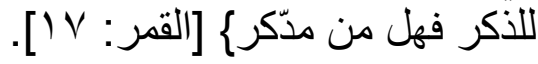

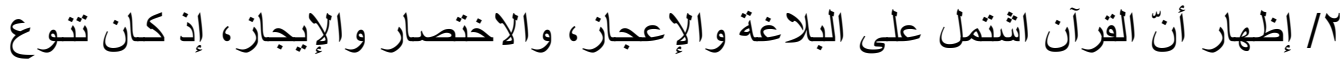

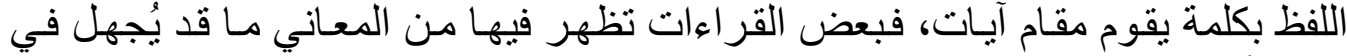

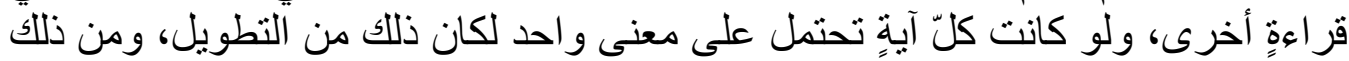

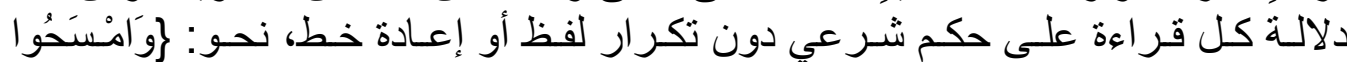

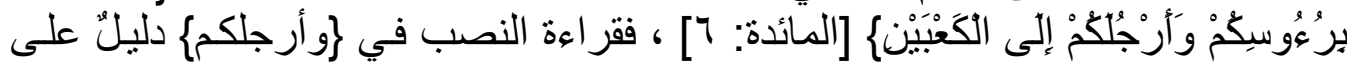

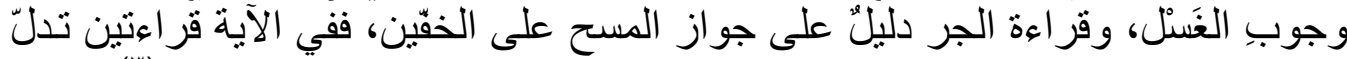

على حكمين متغايرين، ولو لم يكن كذللك لاحتاج كل حكم إلى آية خاصة لبن لبيانه (").

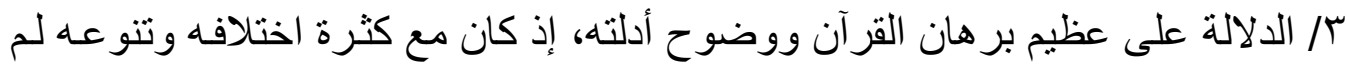

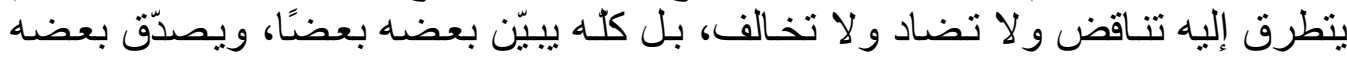

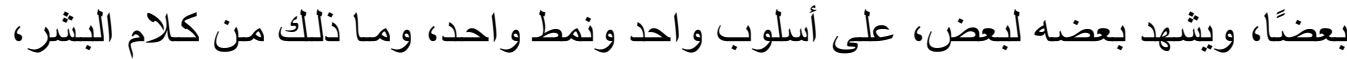

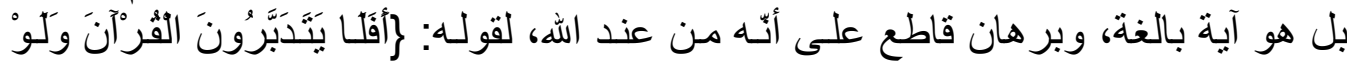

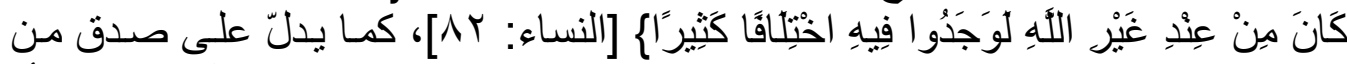

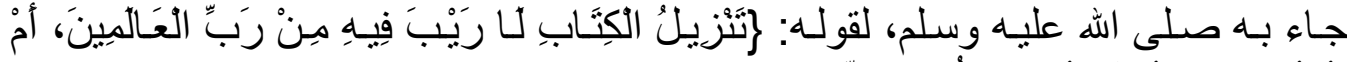

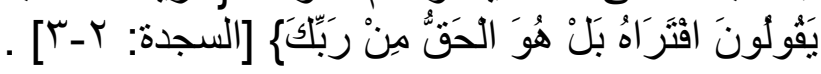

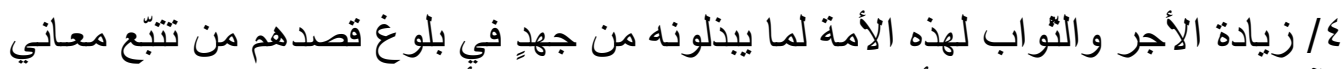

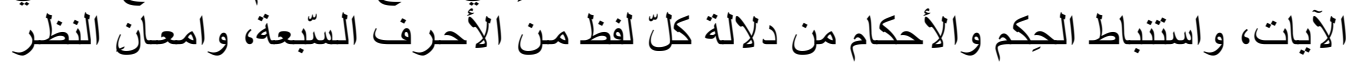

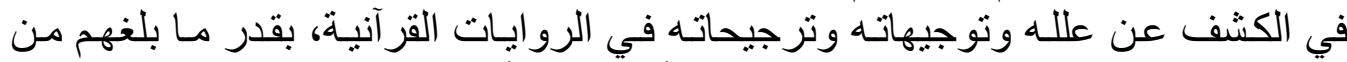

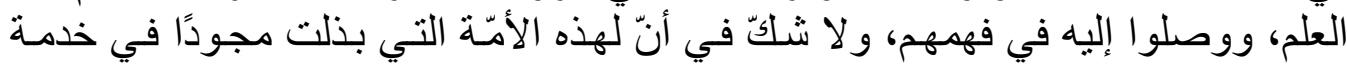

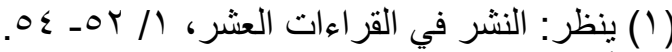

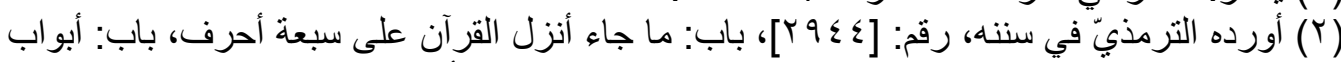

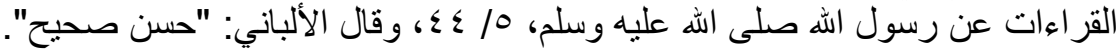

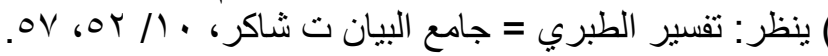


كتاب اله أجرًا عظيمًا، قال تعالى: (فاستجاب لهم ربهم أني لا أضيع عمل عامل منكم من ذكر أو أنتى\{ [ال عمران: 90 1 19.

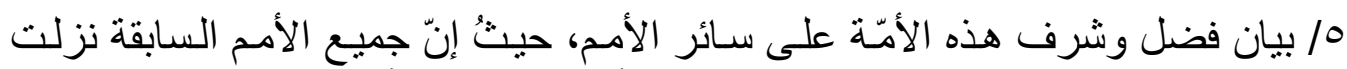

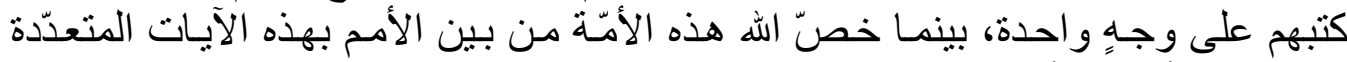

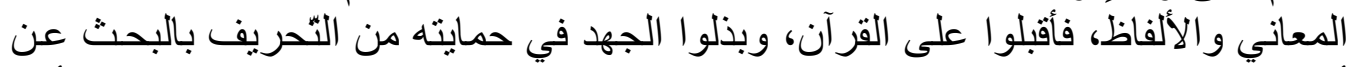

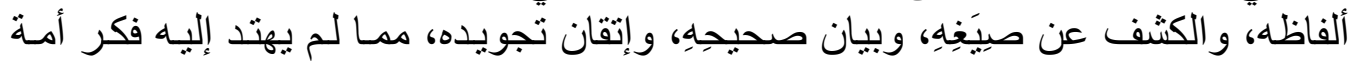
من الأمم، و لا يوصل إليه إلا بإلهام بارئ النسم.

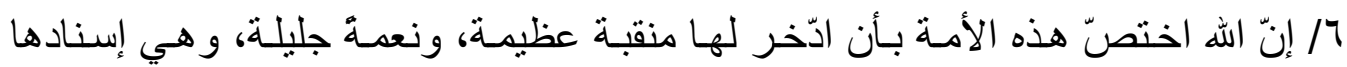

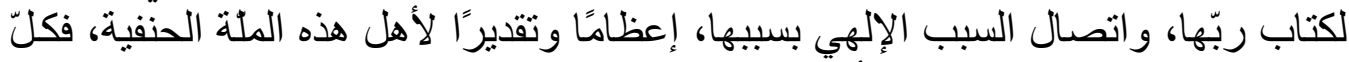

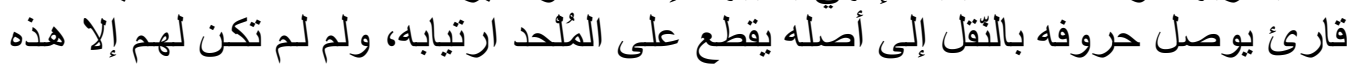
الخصنيصة النّبيلة لكفت.

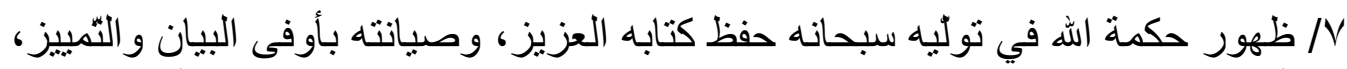

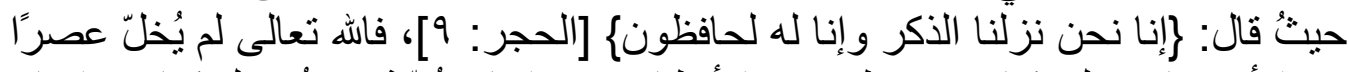

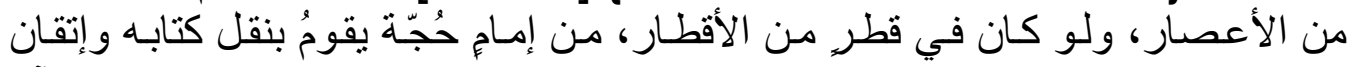

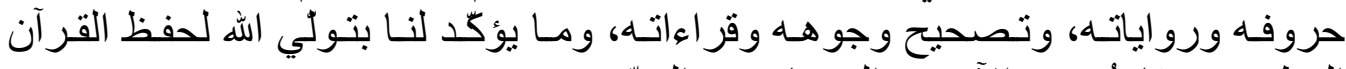
العظيم هو بقاؤهُ حتى الآن في المصاحف ورن و الصنّدور. 


\section{الخاتمة}

وفي نهاية البحث توصّلتُ إلى أبرز التَّائج و الثّوصيات، وهي:

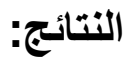

أولا: تختلف القراءات من حيثُ القبول إلى عدّة أنواع هي: المقبولة، والمردودة، و الثنّاذة. ثانيًا: القراءات المقبولة هي القسم الوحيد الذي له صلة بالثقسير.

ثالثَّا: ليست كلّ القراءات لها تعلّق بالثفسير، فمنها ما حفِظ اللغة، ومنها ما يزيدُ في تفسير

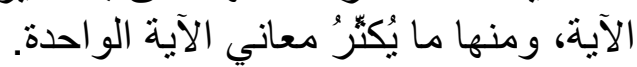

رابعًا: إنّ الاختلاف الو اقع في القر آن كله اختلاف تنوّع، لا اختلاف تضادّ.

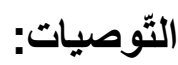

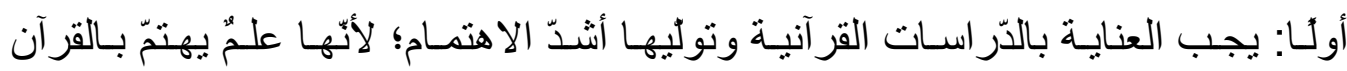
الكريم.

ثانيًا: يجب الاعتبار بأنواع القراءات من حيثُ القبول والرّدّ، والأخذ بـالمقبول منها، ورَدِّ

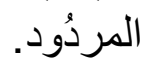

ثنالثا: لا بُدَّ من تدبّر حكمة الله في اختلاف القراءات، وشكر الله على هذه النّعمة العظيمة.

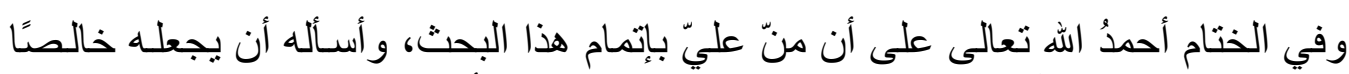

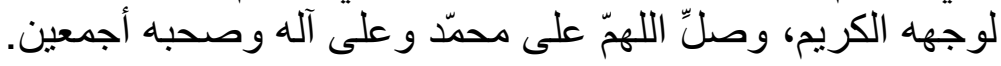




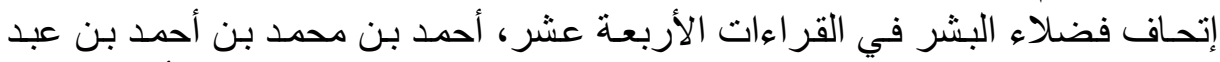

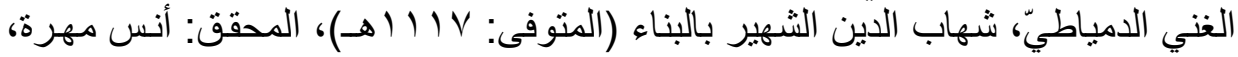

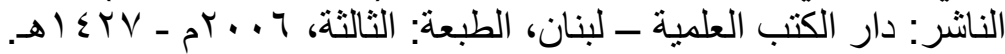

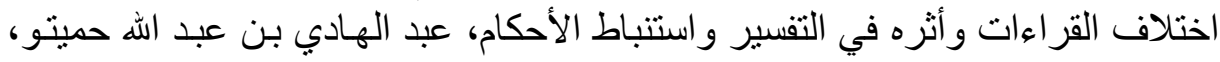

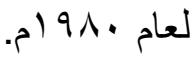

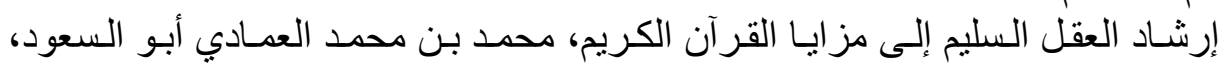

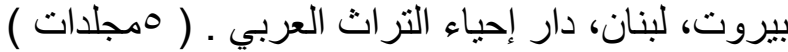

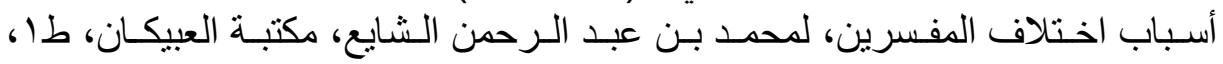
$.01 \leqslant 11$

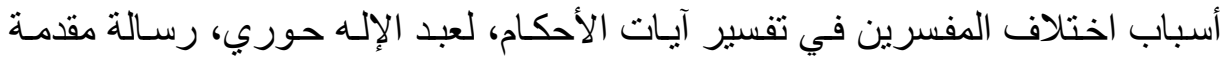

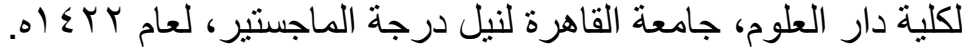

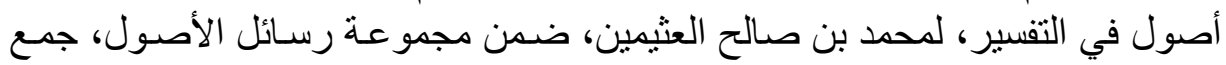

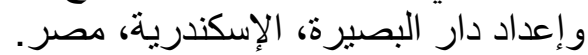

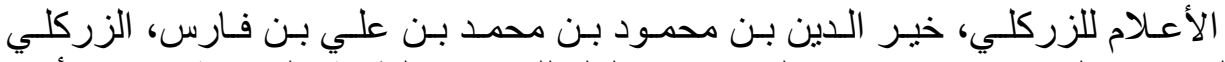

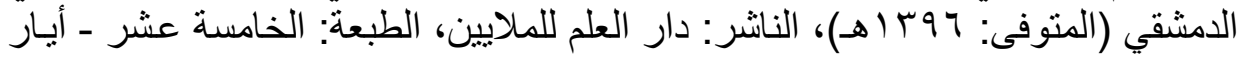

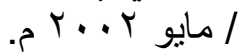

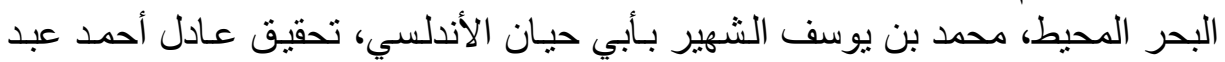

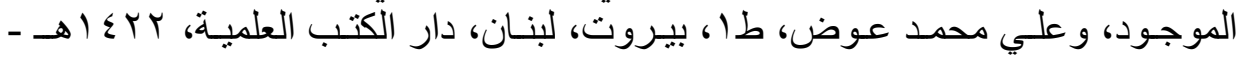

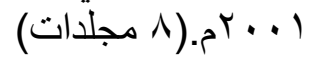

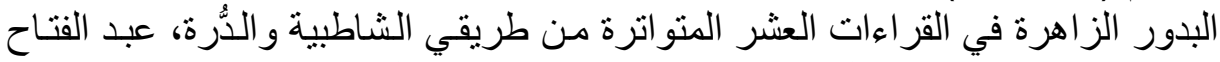

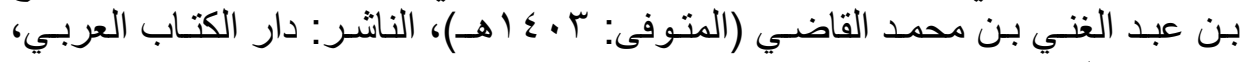
بيروت - ل بينان.

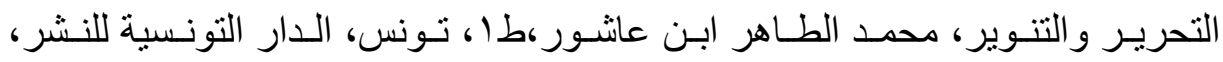

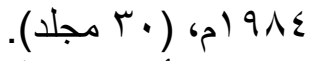

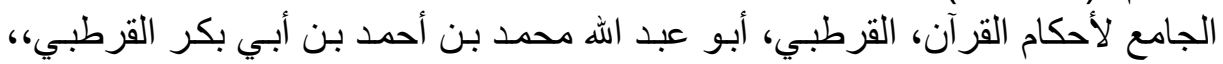

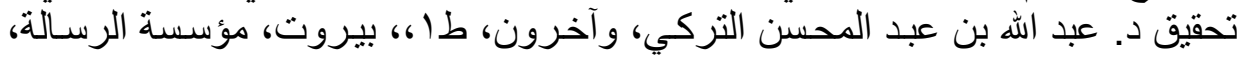

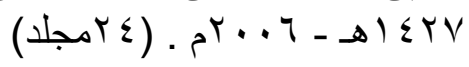

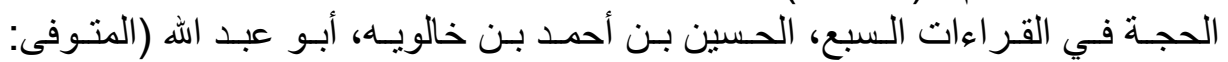

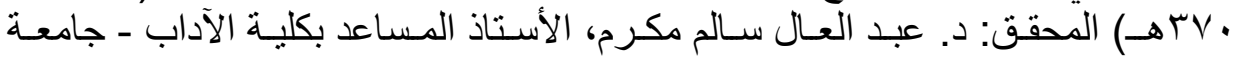

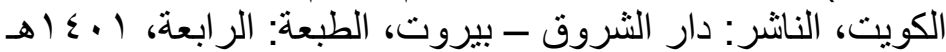

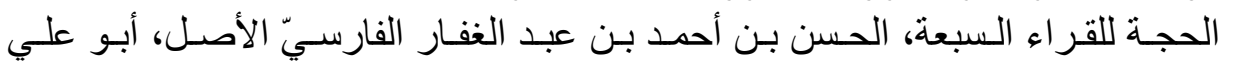

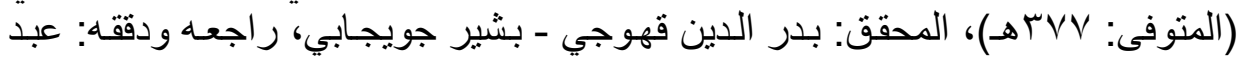

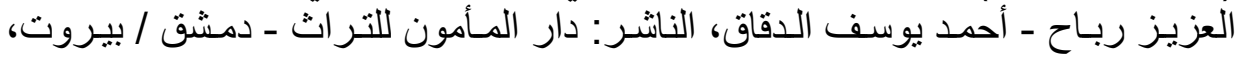

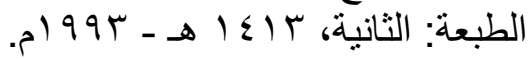

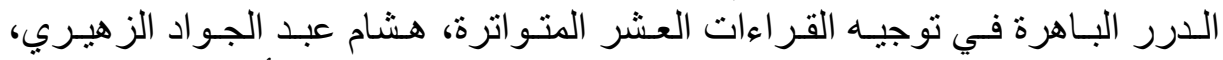

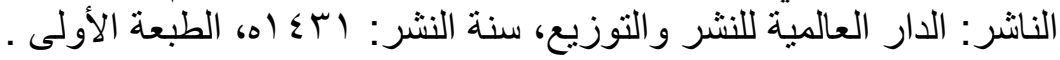




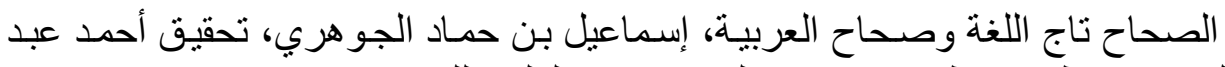

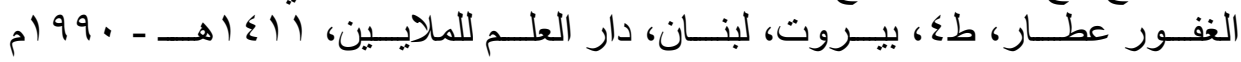

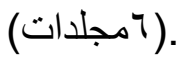

القر اءات و أثر ها في التفسير و الأحكام، محمد بن عمر بن سالم بازمول، عام با إ؟ اهـ.

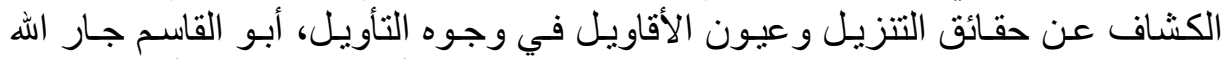

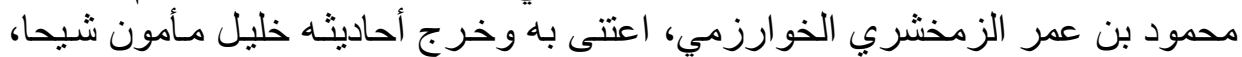

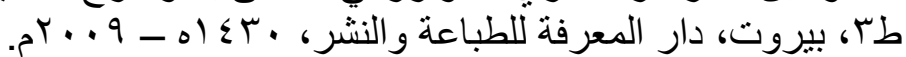

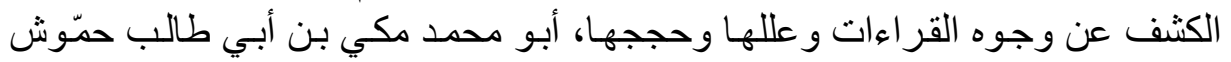

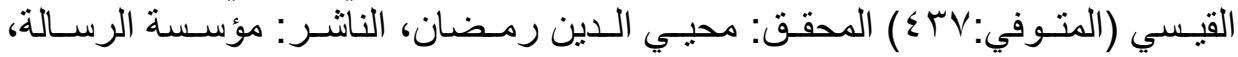

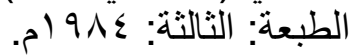

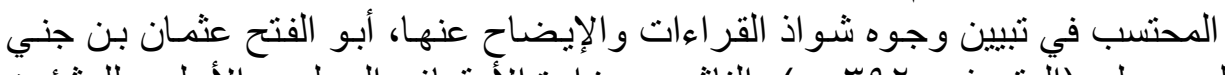

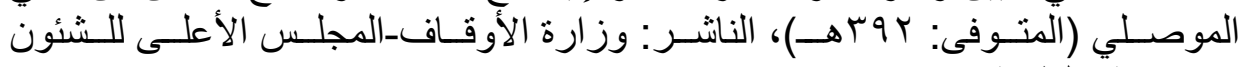

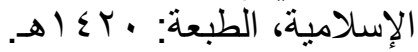

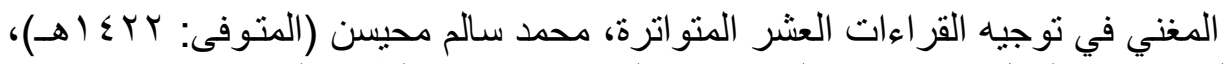

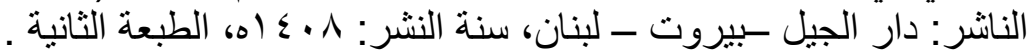

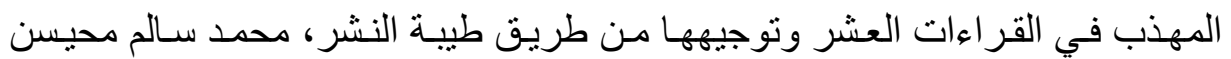

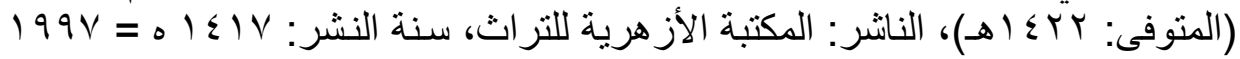

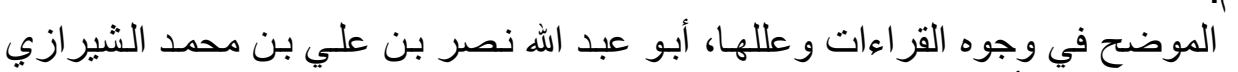

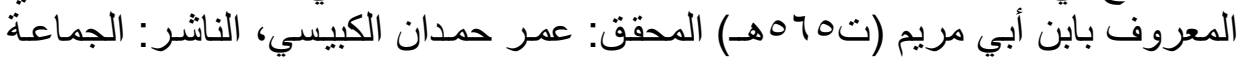

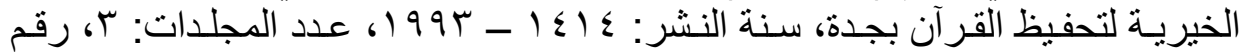

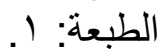

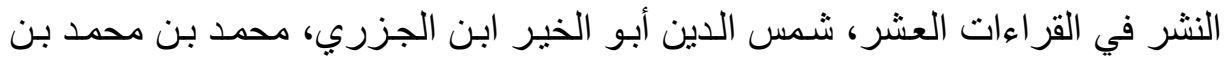

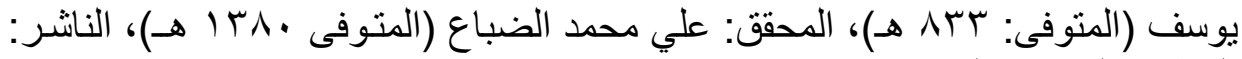

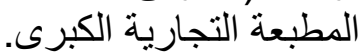

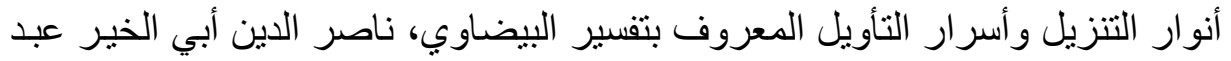

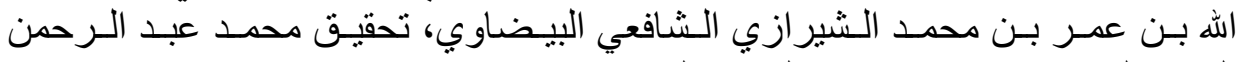

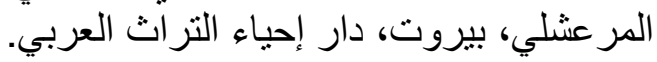

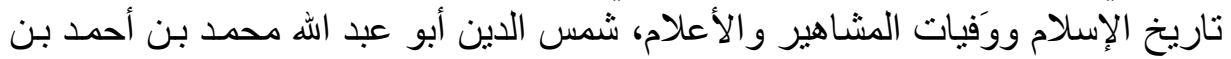

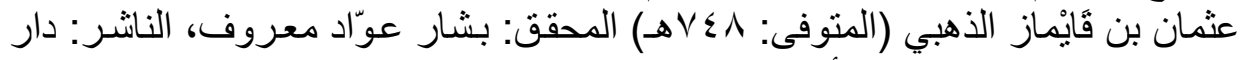

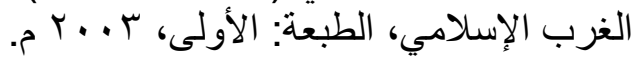

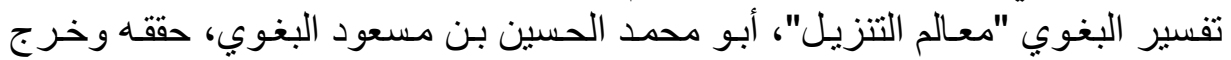

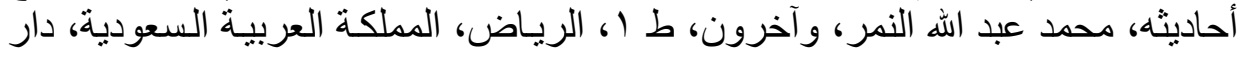

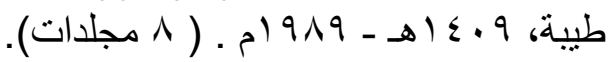

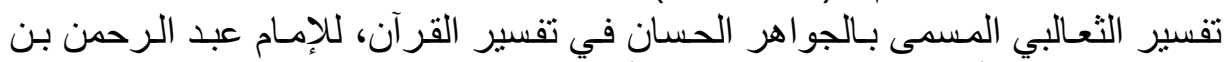

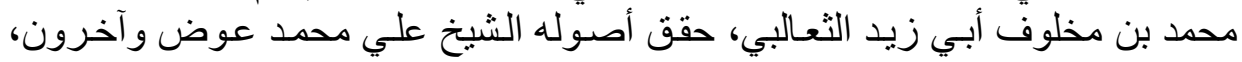

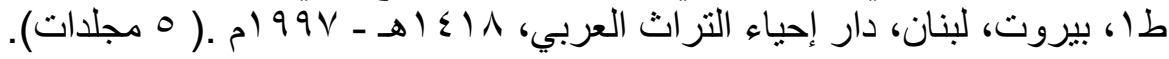




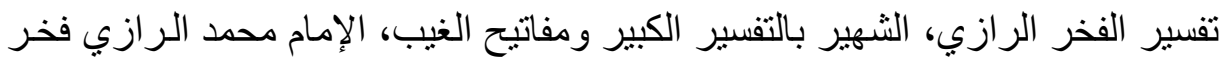

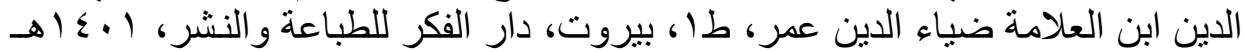

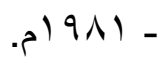

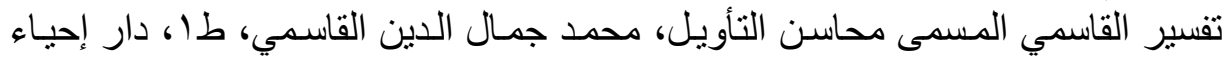

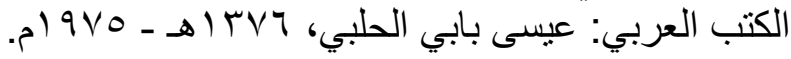

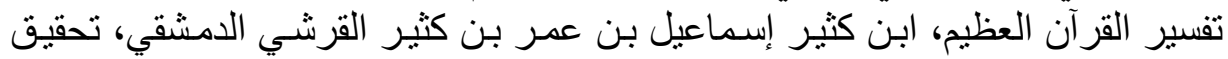

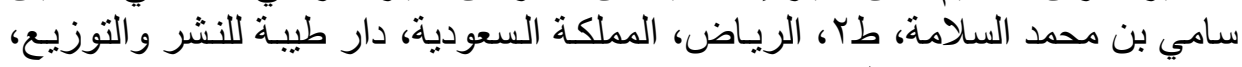
.

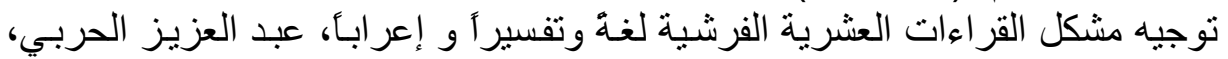

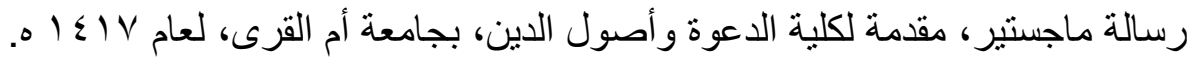

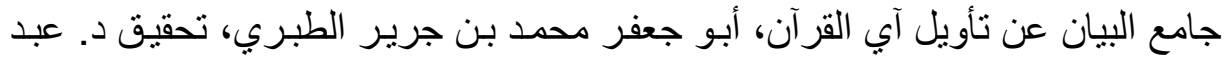

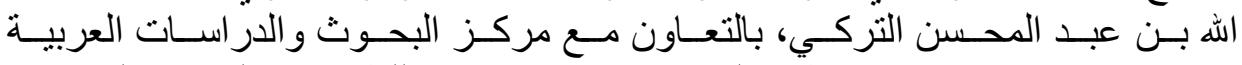

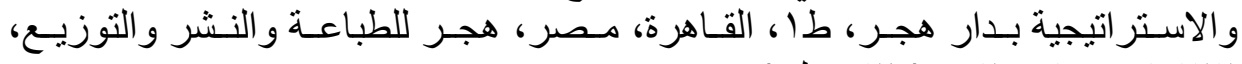

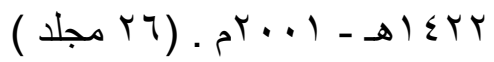

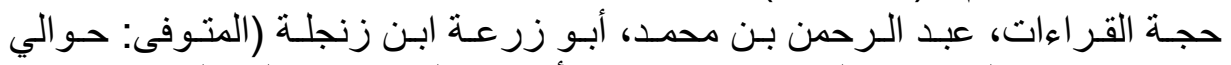

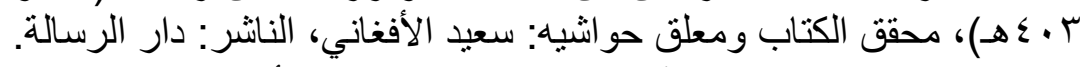

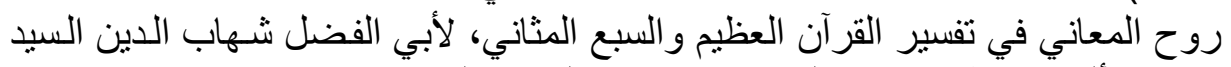

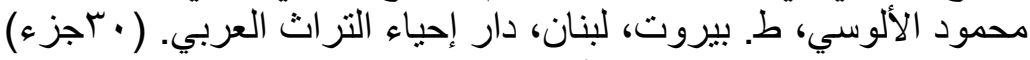

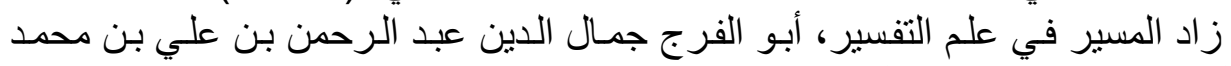

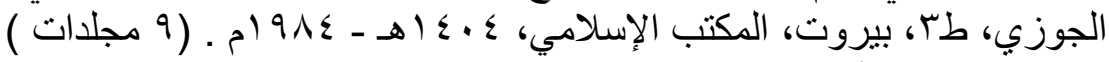

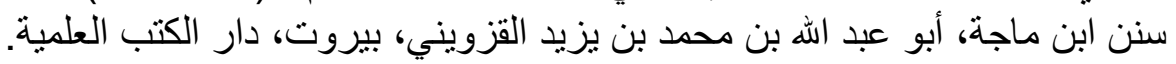

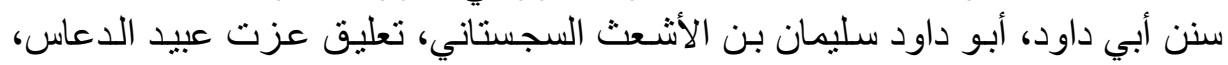

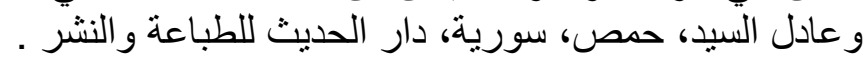

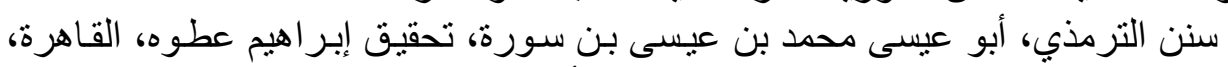

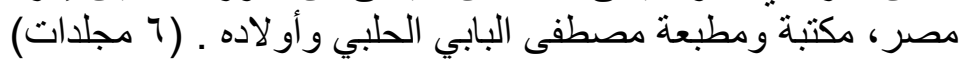

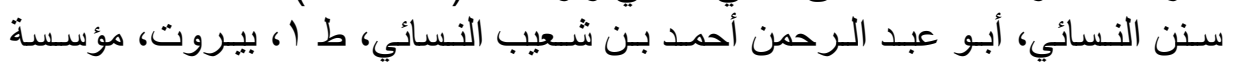

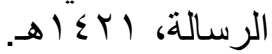
سير أعلام النبلاء، شمس الدين أبو عبد الهُ اله محمد بن أحمد بن عثمان بن قُائمـاز الذهبي

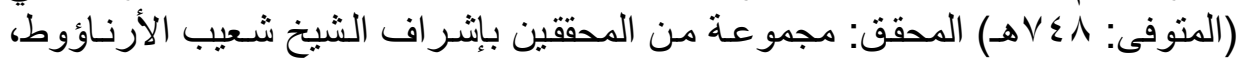

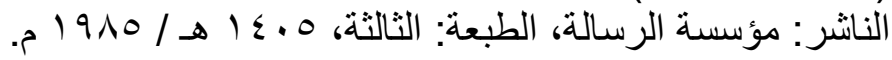

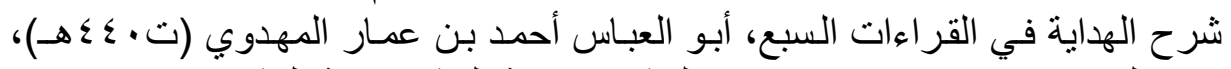

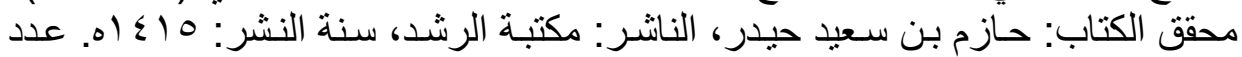

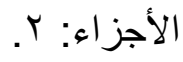
شرح مقدمة في أصول التفسير، لابن تيمية، لمحمد بن عمر بازمول، دار الإمـام أحمد،

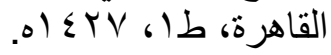
شـرح مقدمـة في أصـول التفسير، لابـن تيميـة، لـسـاعد بـن سليمان الطيـار، دار ابـن

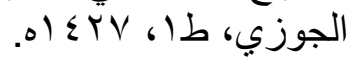




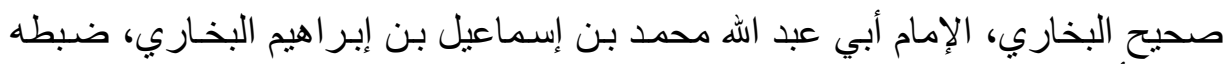

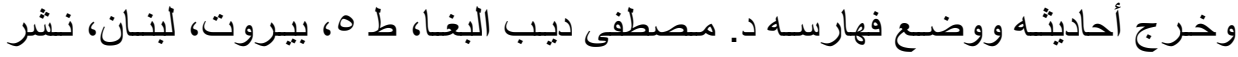

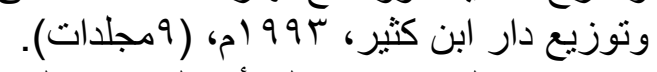

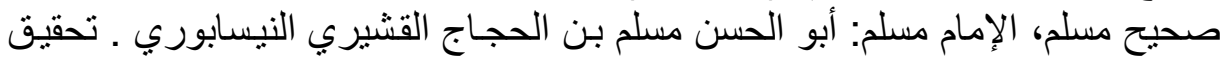
محمد فؤاد عبد الباقي، دار إحياء الكتب العام العربية.

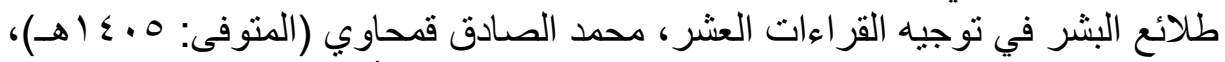

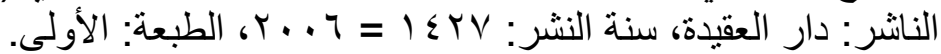

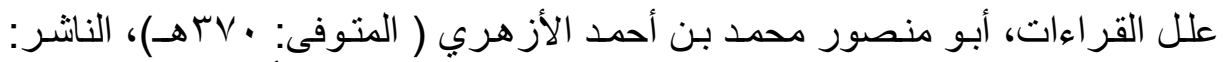

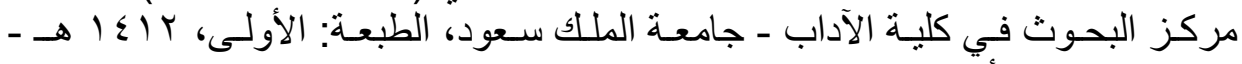

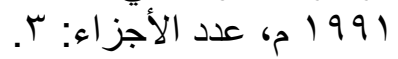

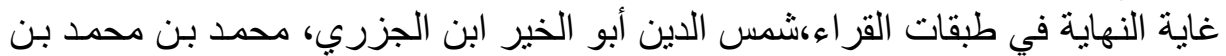

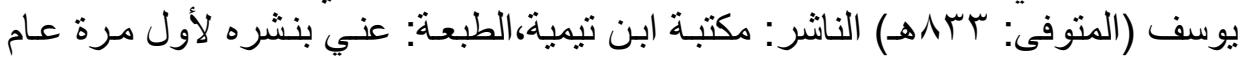

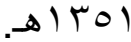

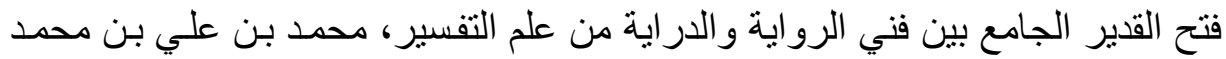

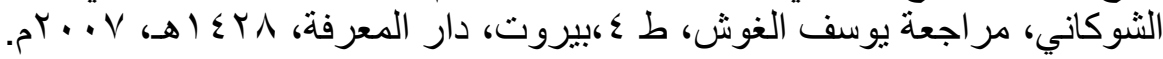

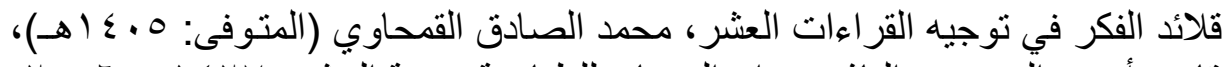

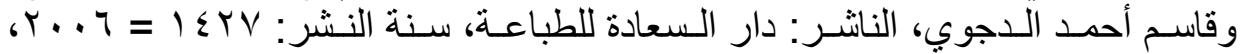

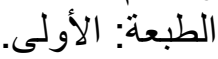
لسان العرب، ابن منظور : أبو الفضل جمال الدين محمد بن مكرم بن منظور، بيروت،

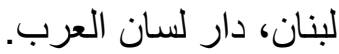
معاني القرآن و إعر ابه، الزجاج: أبي إسحاق إبر اهيم بن السري، شرح إن وتحقيق دكتور

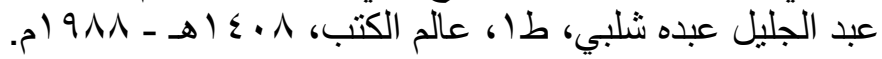

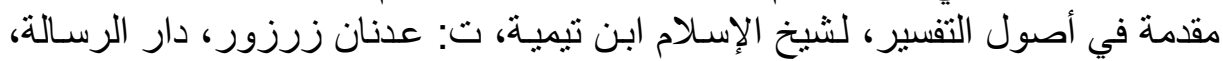

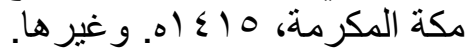

